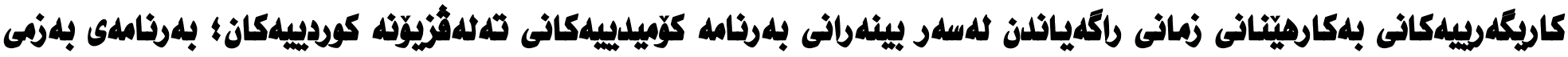

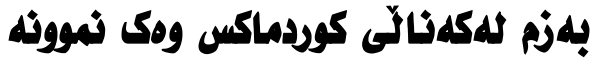

شوان ئادهم ئلهرثهل

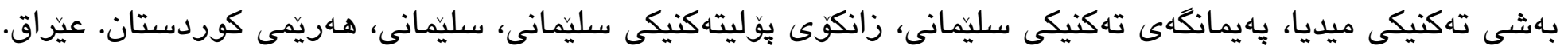

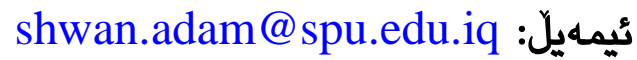

\section{مههاباد كامل عهبلدولآ}

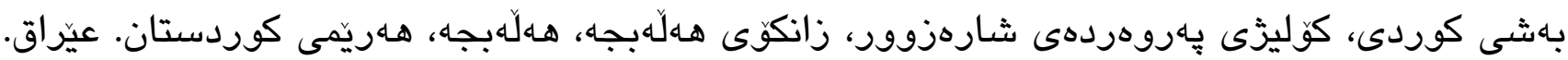
mahabad.abdullah@uoh.edu.iq :يمهيلّ

צوخته:

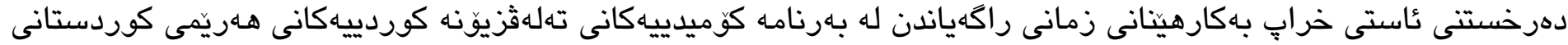

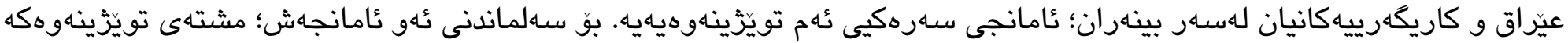

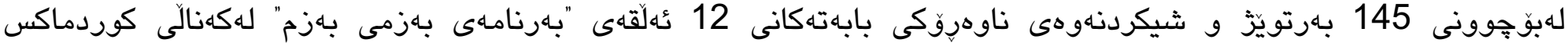

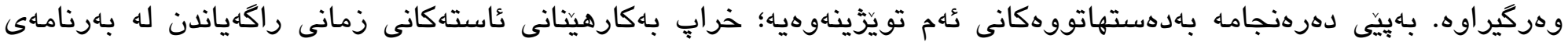

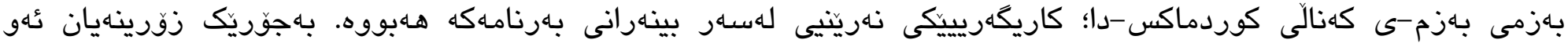

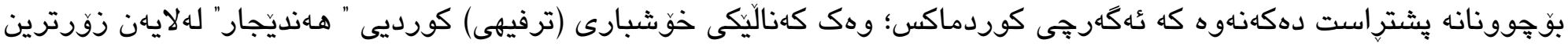

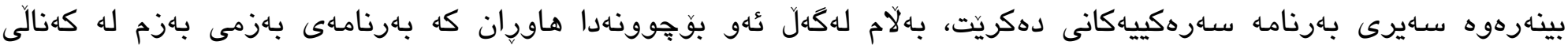

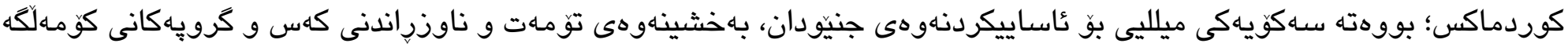

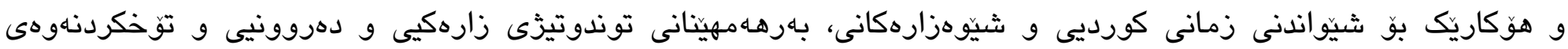

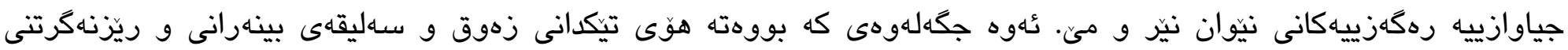

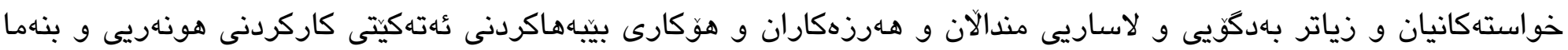

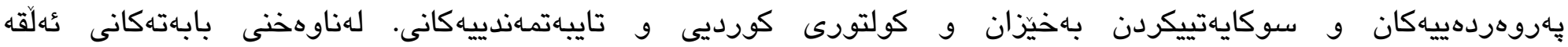

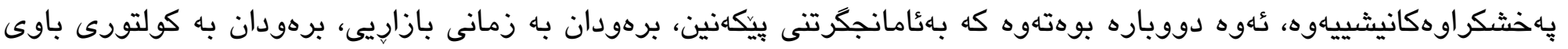

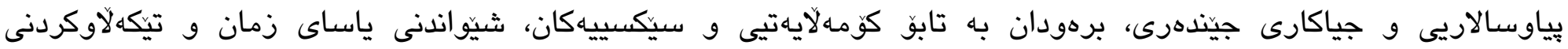

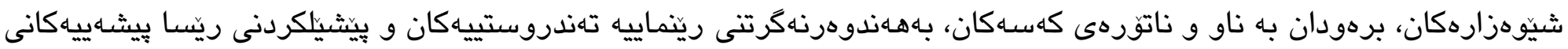

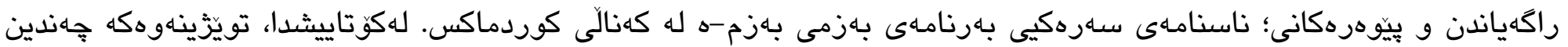




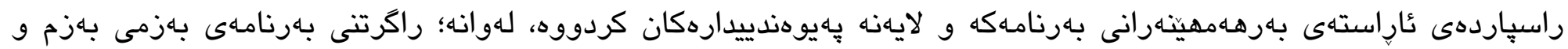

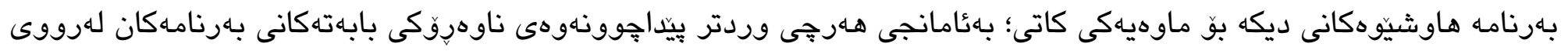

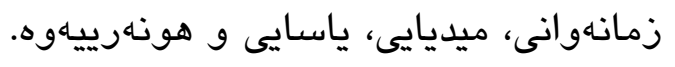

كليله وشُكان: زمان، زمانى راكهياندن، بهرنامهى كوميدى، تهلهثزيونه كوردييهكان، ريّا بيشهييهكانى راكهياندن

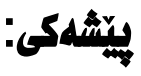

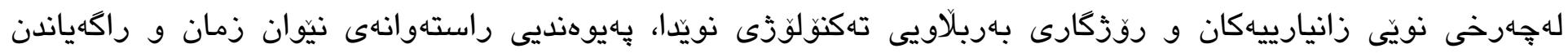

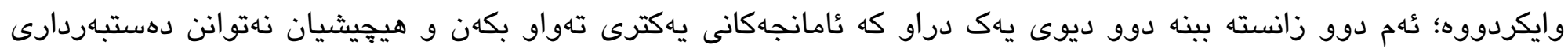

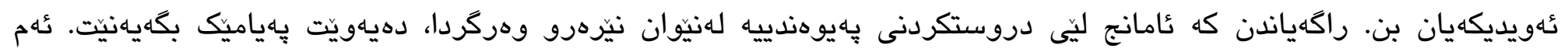

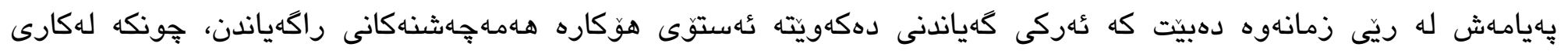

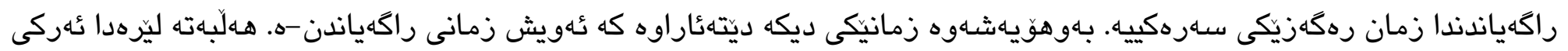

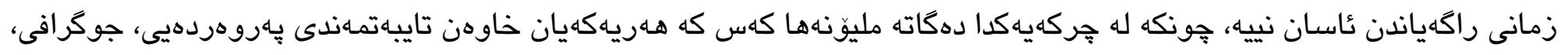

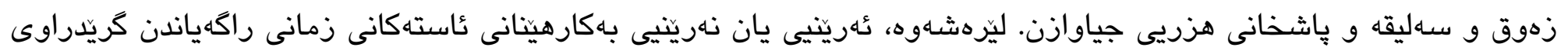

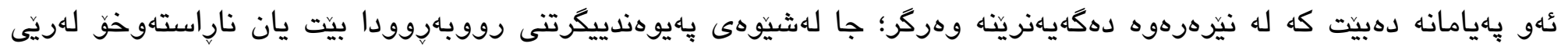

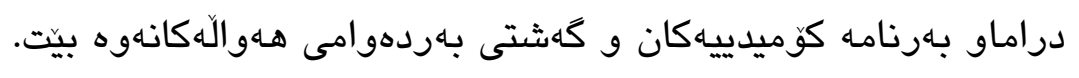

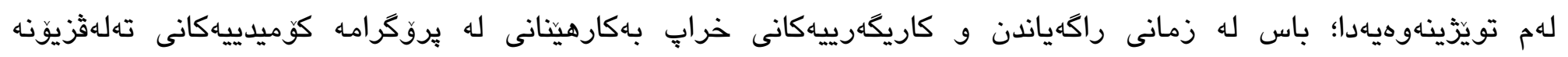

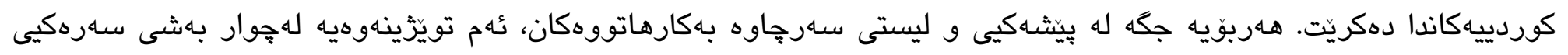

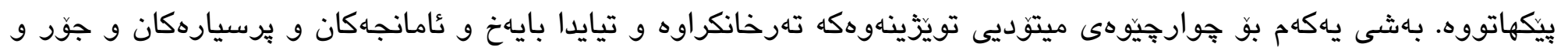

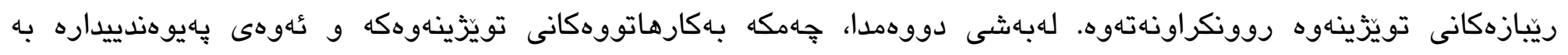

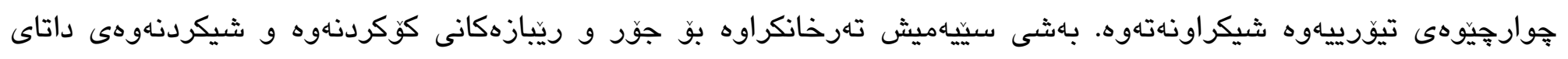

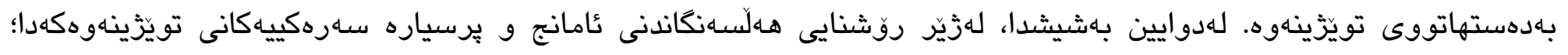

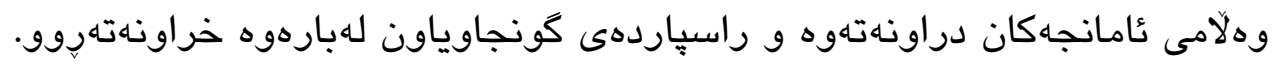

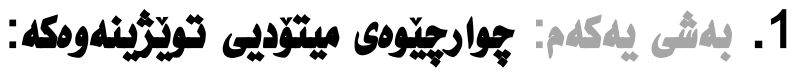

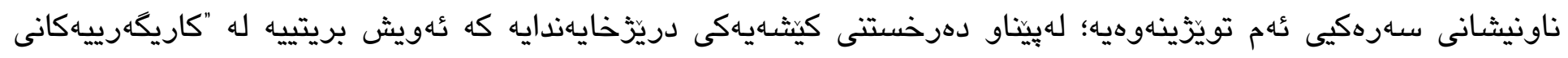

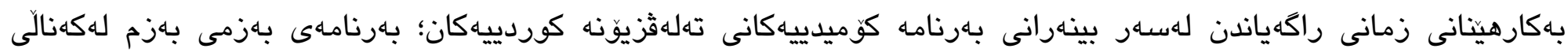

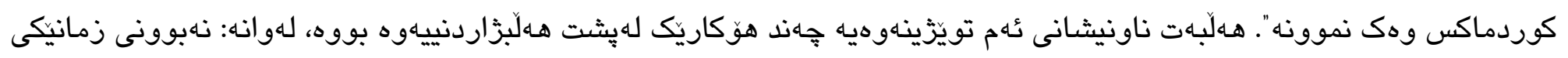

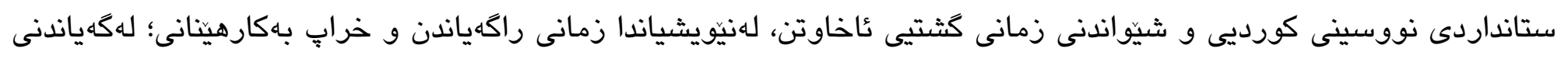

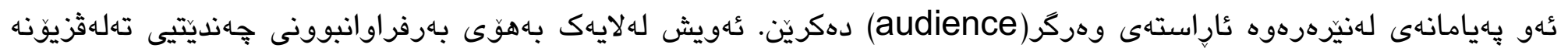

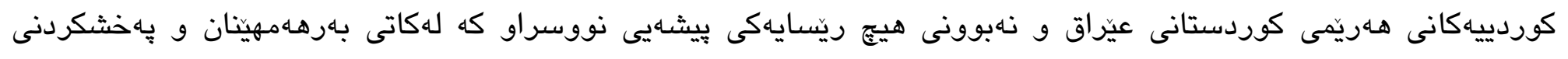

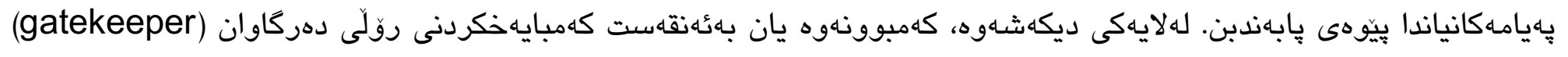

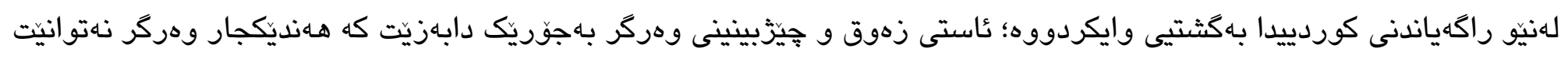




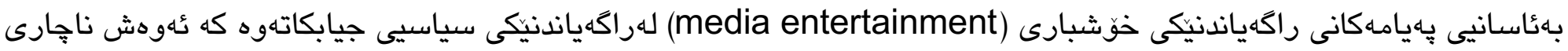

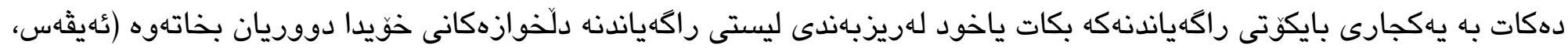

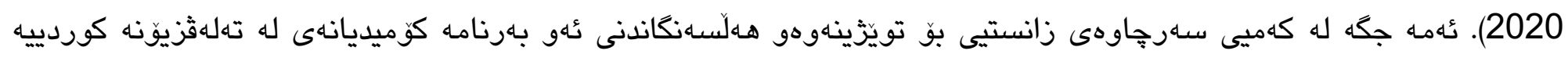

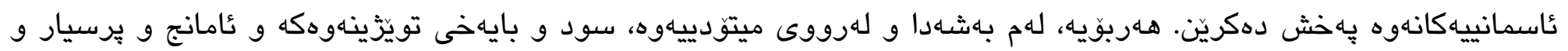

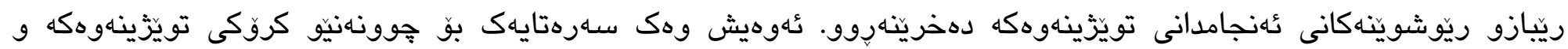

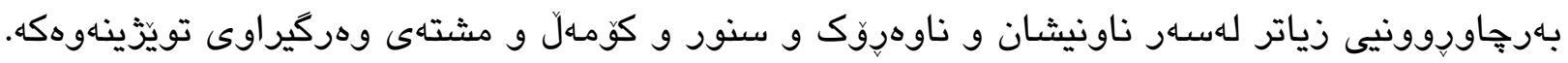

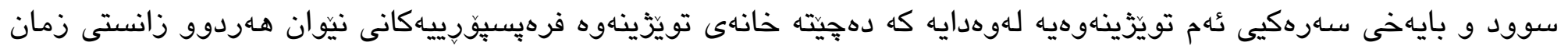

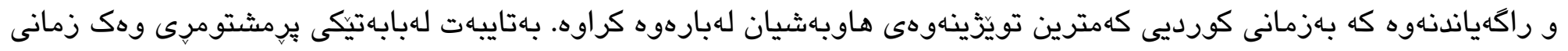

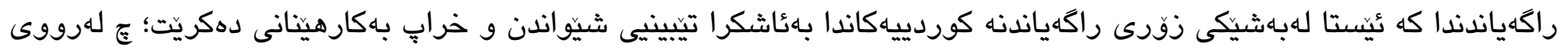

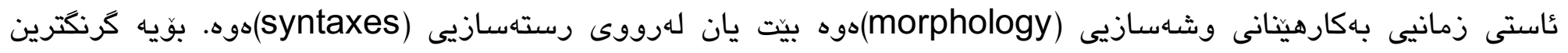

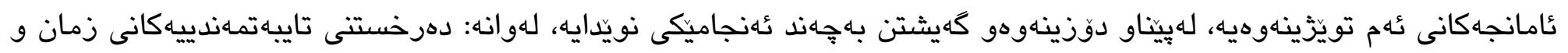

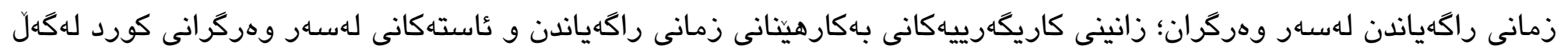

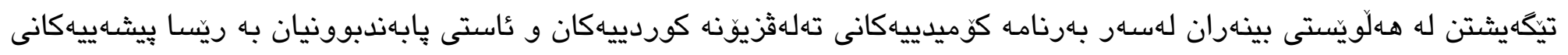

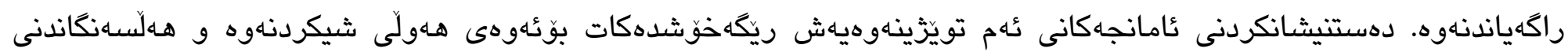

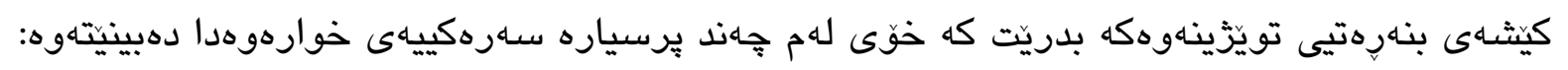
1. ثايا ع جوّريكى عاستهكانى زمانى راكهياندن؛ كاريكهريى لهسهر بهرههمهينانى بهرنامهى كؤميديى بهزمى بهزم لهكهنالى

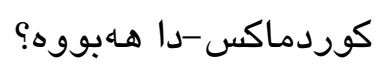

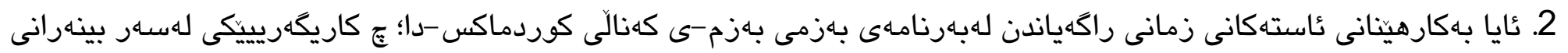

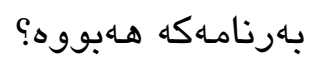

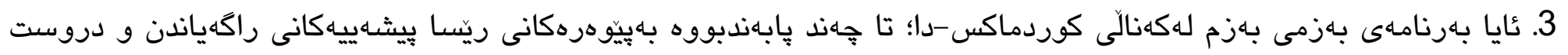

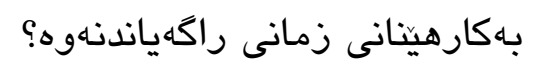

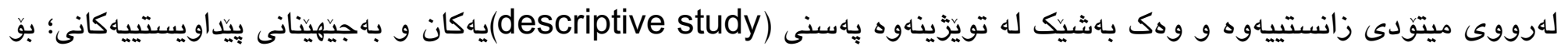

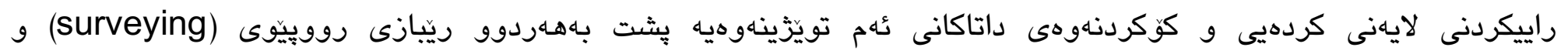

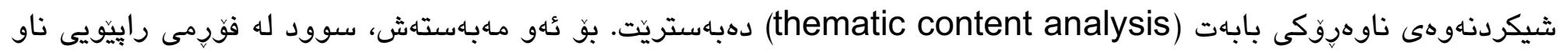

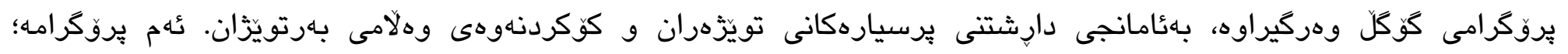

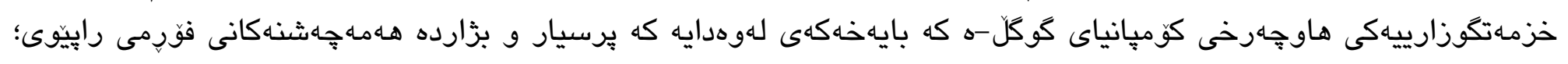

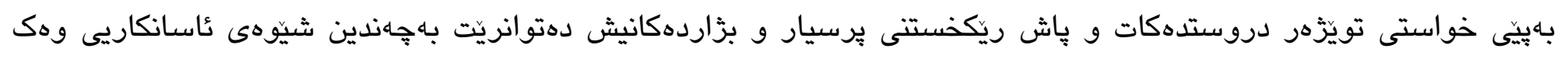

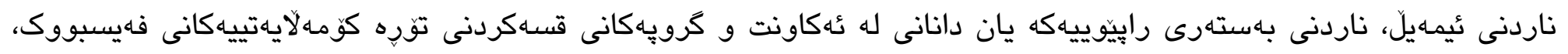

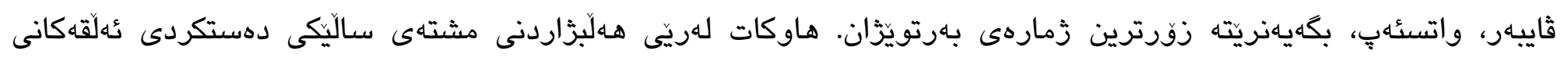

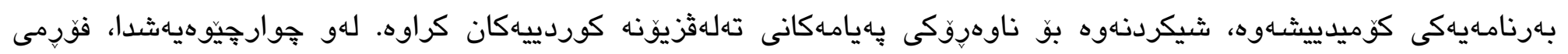

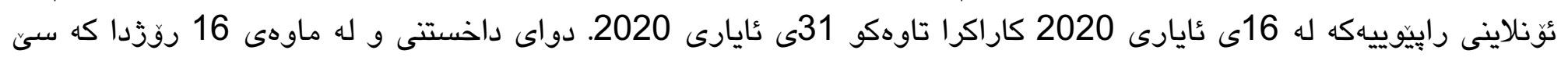

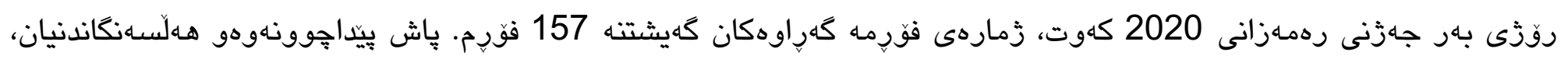




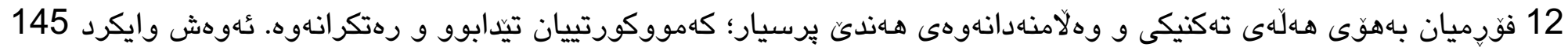

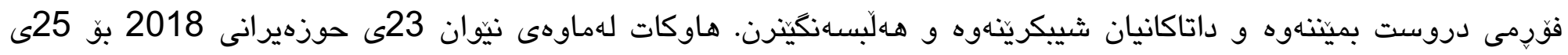

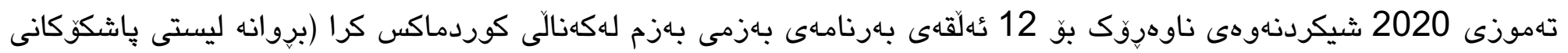

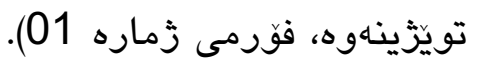

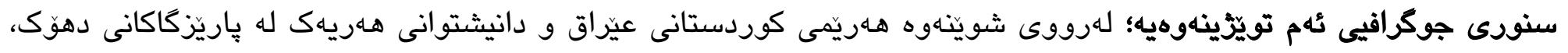

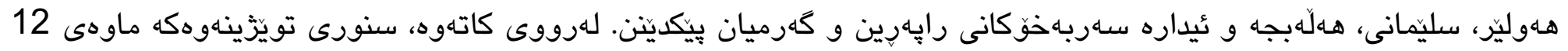

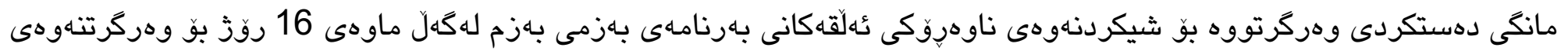

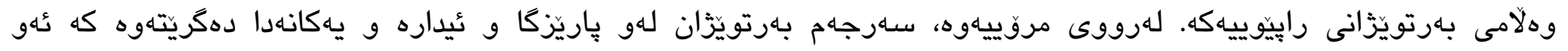

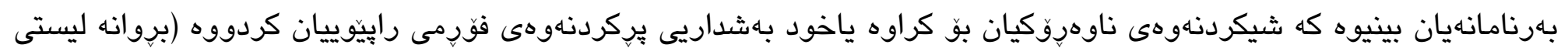

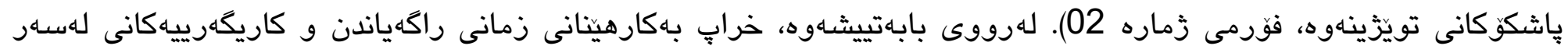

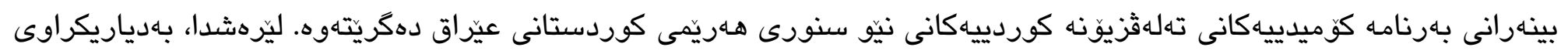

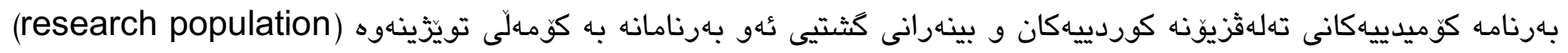

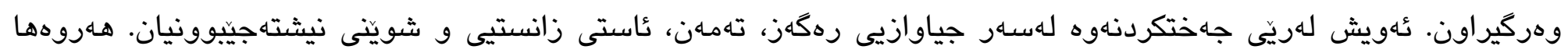

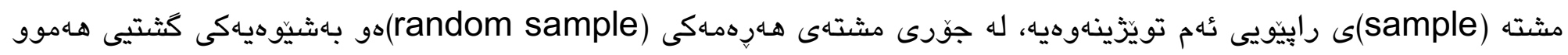

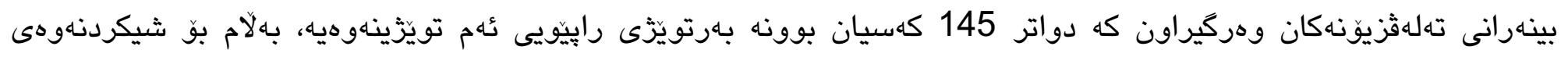

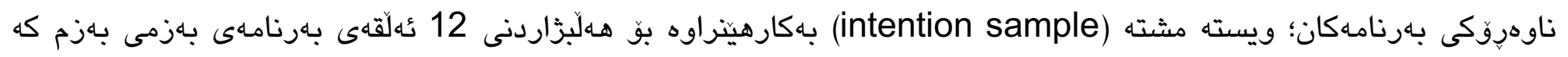

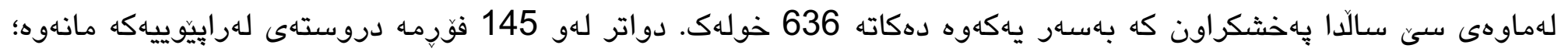

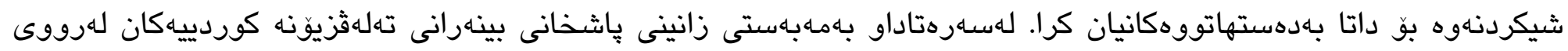

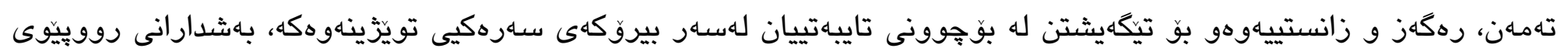

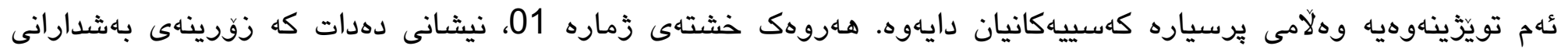

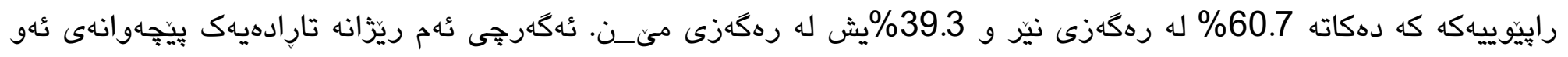

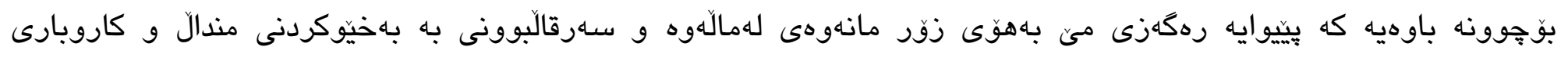

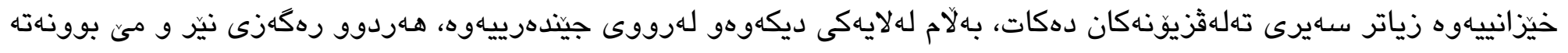

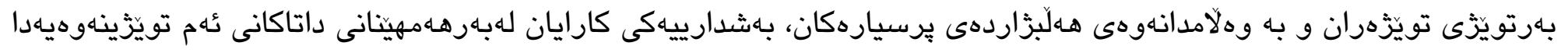
كردووه.

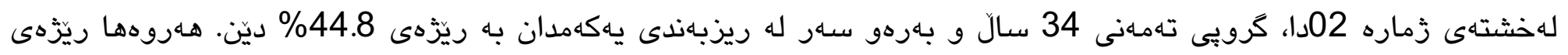

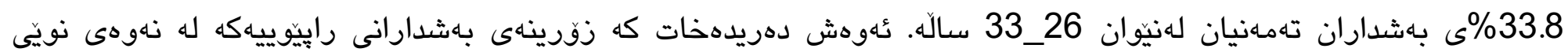

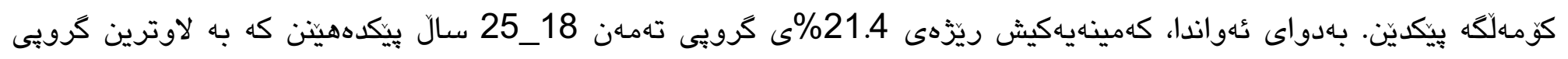

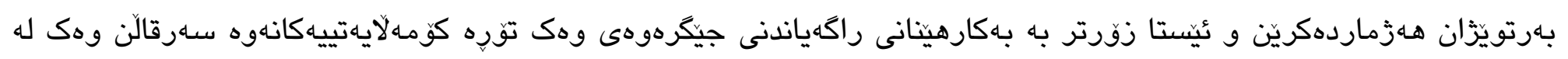

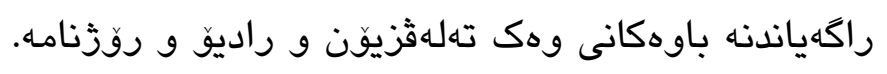

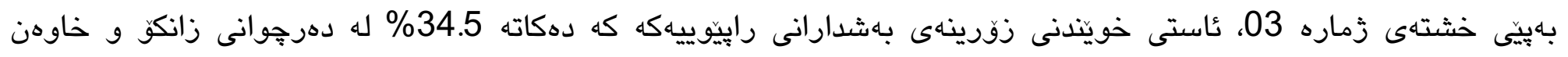

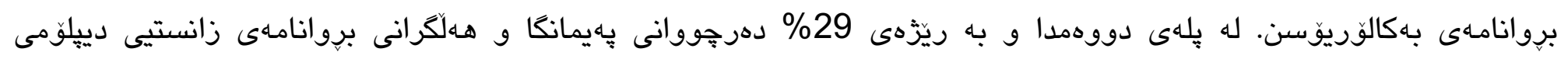

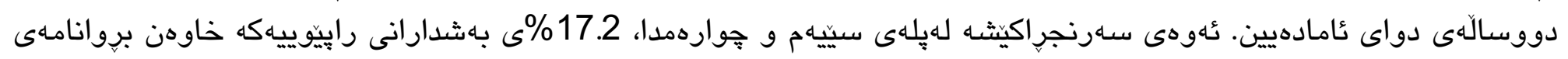




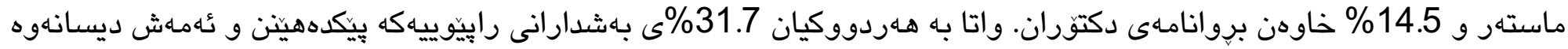

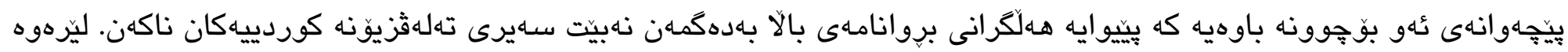

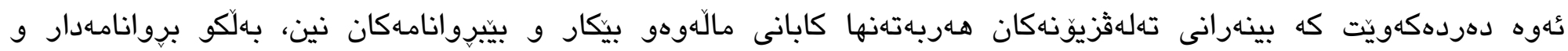

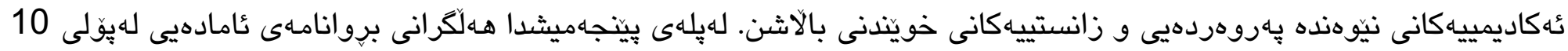

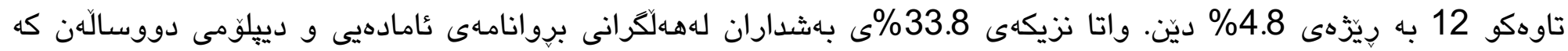

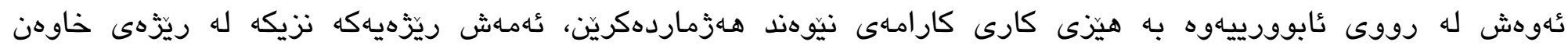

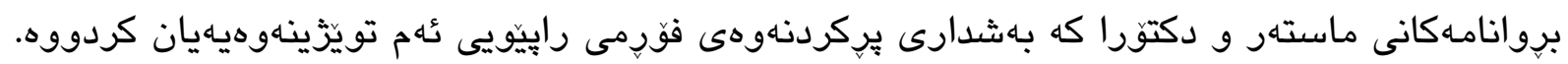




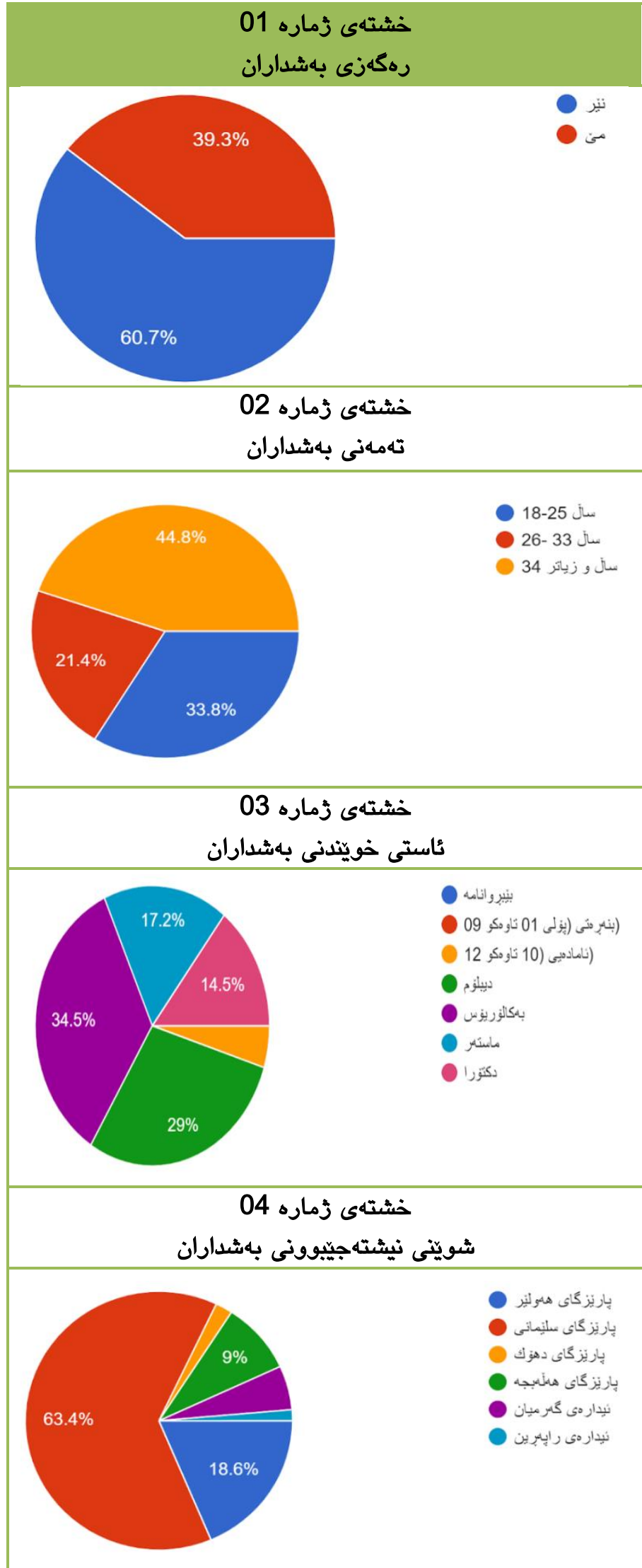

خشتهى زماره 04، نيشانى دهدات كه شوينى نيشته جيّبوونى زورينهى

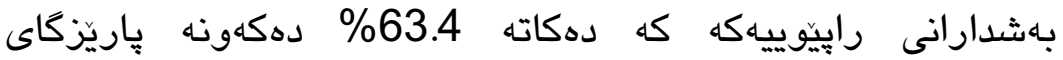

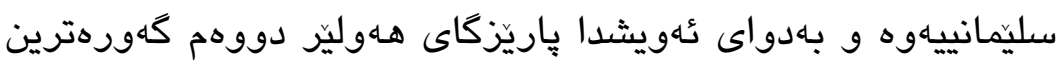

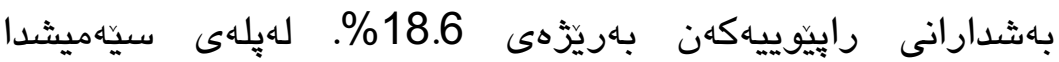

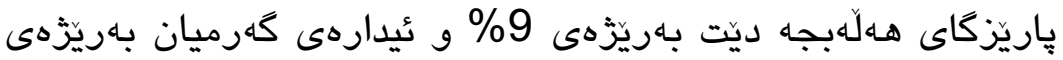

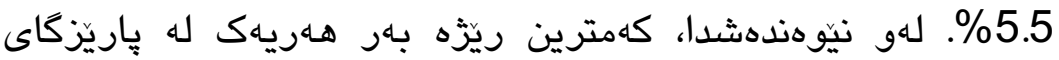

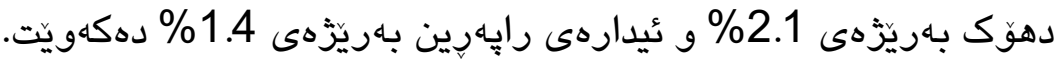

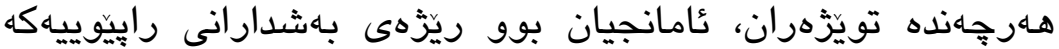

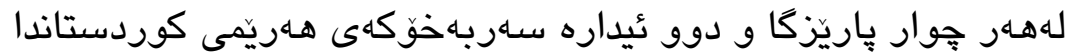

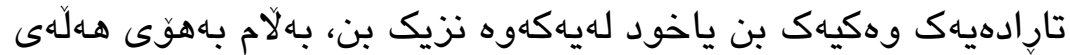

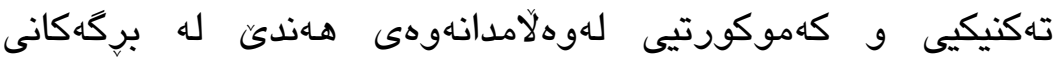

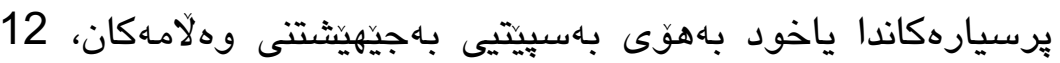

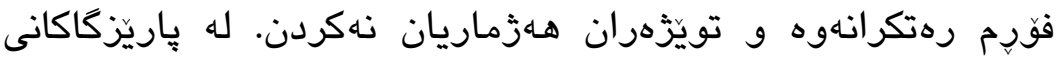

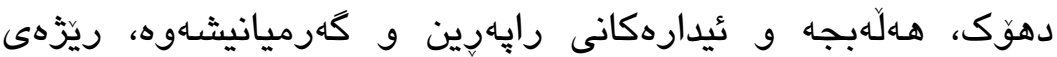

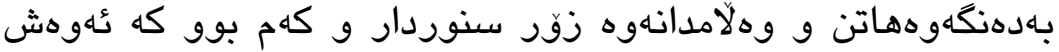

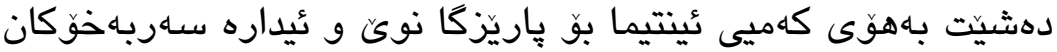
و سنورداريى و دوورهدهستيى ثاستى دهستخاهيشتن بهاهـاهرجاوهكانى

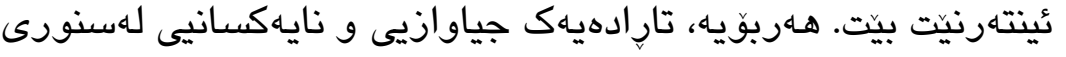

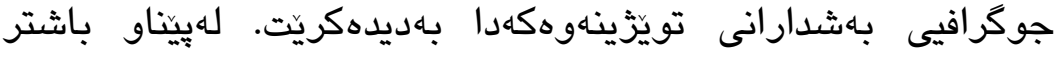

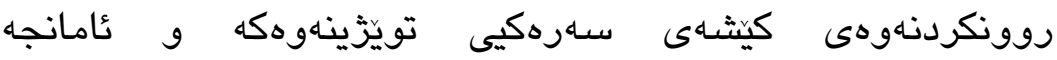

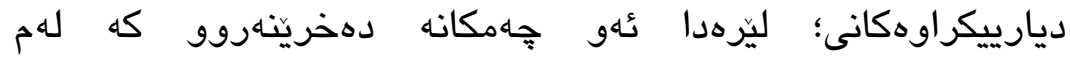

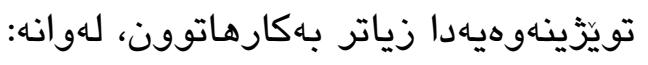

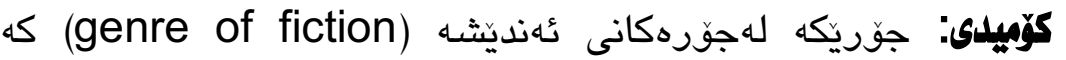

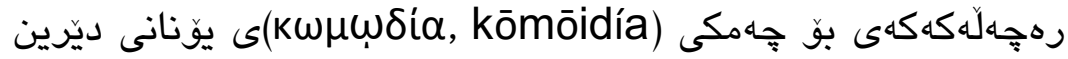

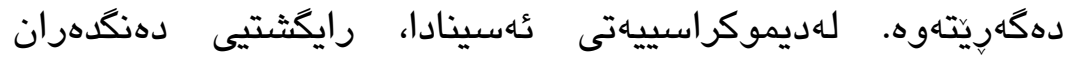

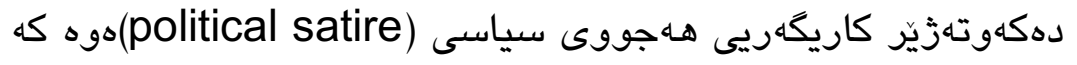

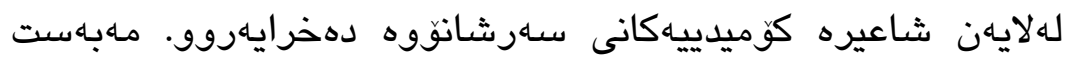

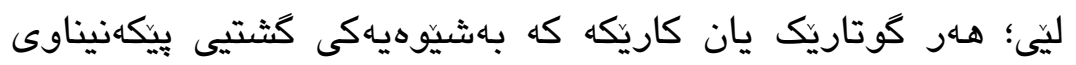

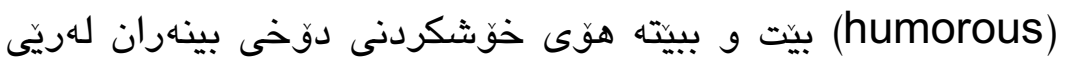

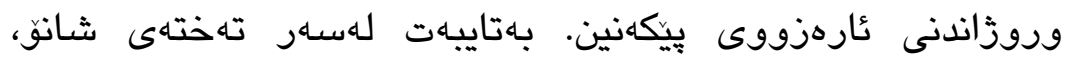
تهلهثَيون، فلم، كوميدياى وهستاو (stand-up comedy) و كتئي

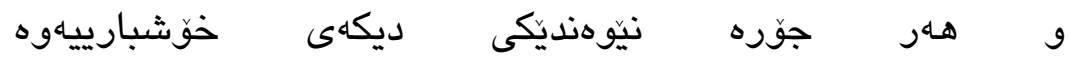
.(Henderson.,1993) 


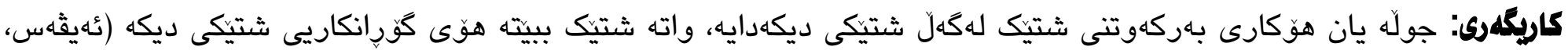

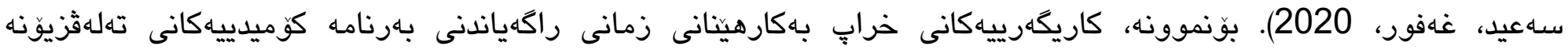
كوردييهكان لهسهر وهركر يان بينهرانيان.

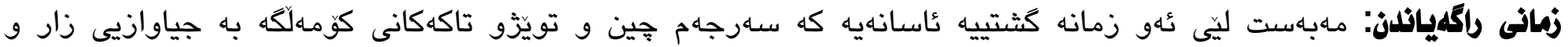

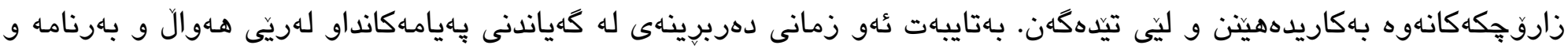

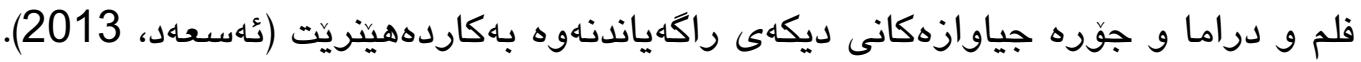

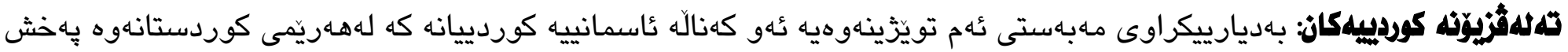

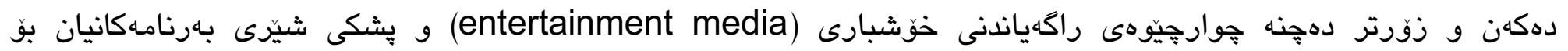

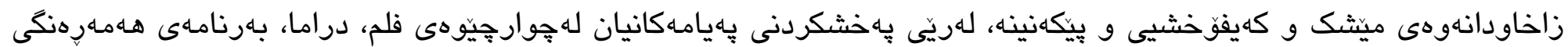

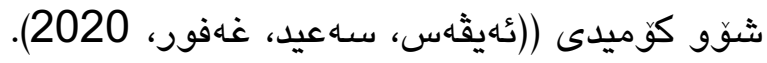

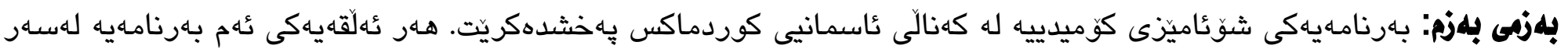

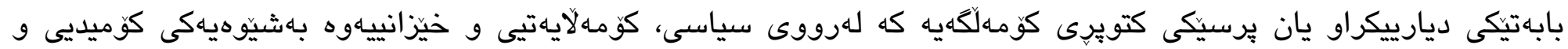

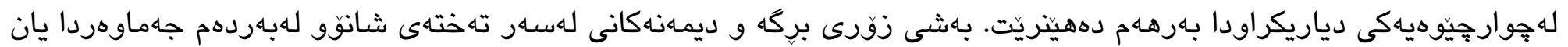

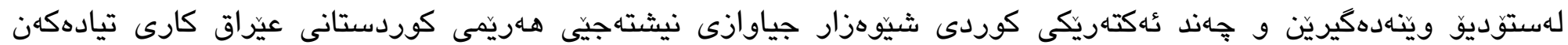
(كوردماكس، 2020). (2020)

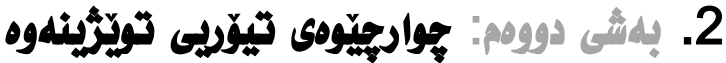

له ريّى بشتبهستن بهسهارجاوهى زانستيى نوى؛؛ لهم بهشهداو لهرووى تيوّرييهوه سهارجهامى ئهو بابهته بِهيوهندييدارانهى بوّ لايهنى

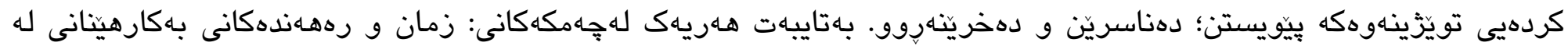

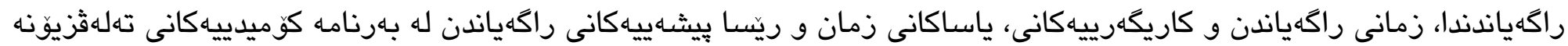

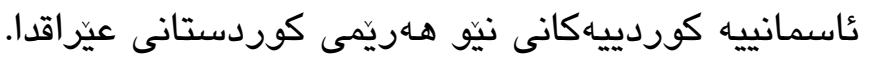

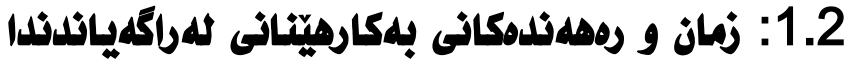

ناساندن و له قالَبدانى دياردهيهكى وهك زمان كاريّكى ئاسان نييه، جونكه زمان خوّى له خوّيدا فره رهههندو فرهجهامسهره، ئهركو

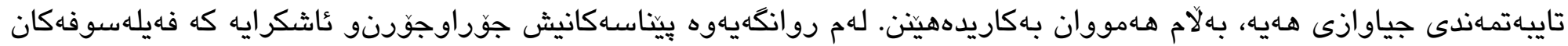

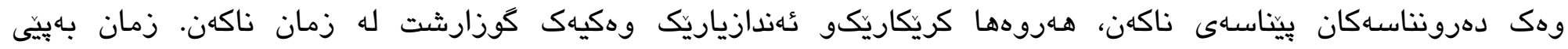

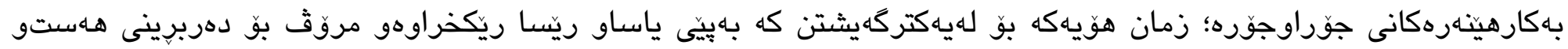

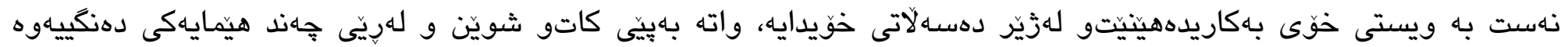

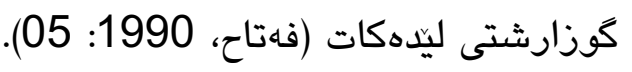




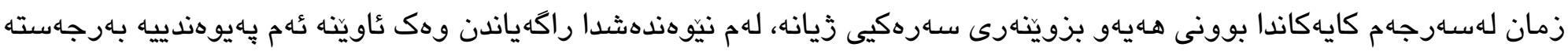

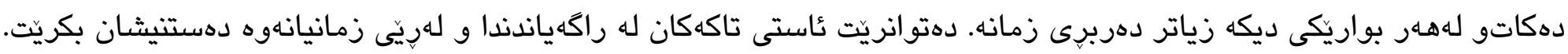

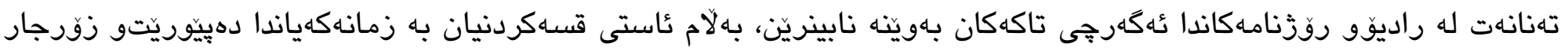

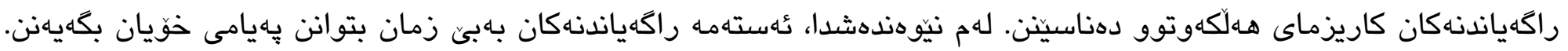

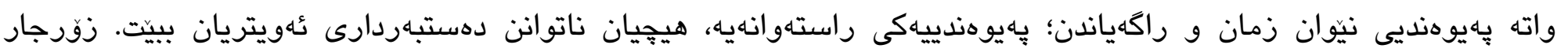

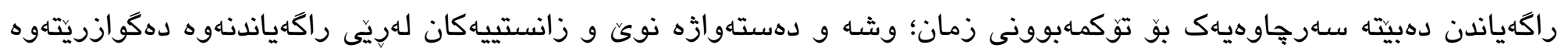

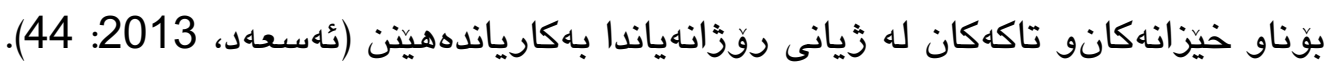

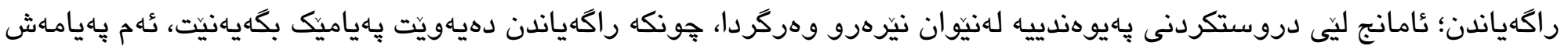

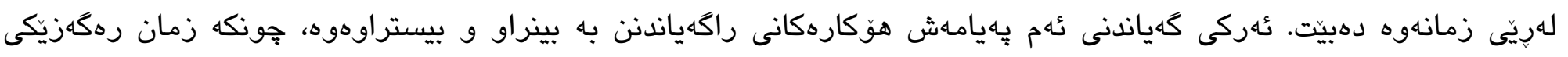

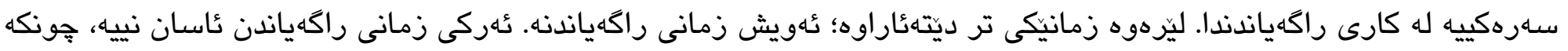

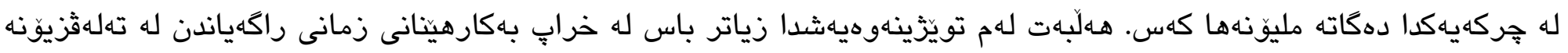

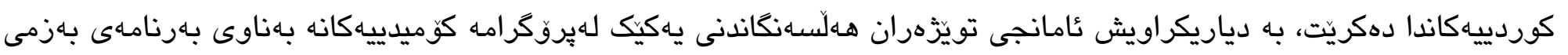

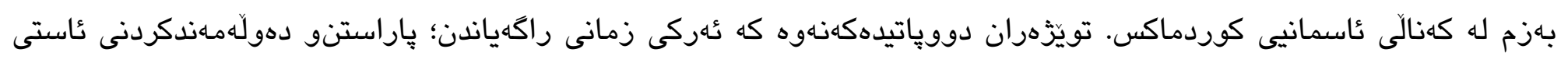

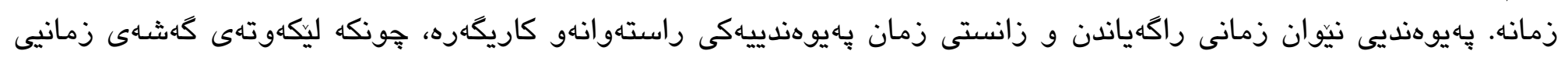

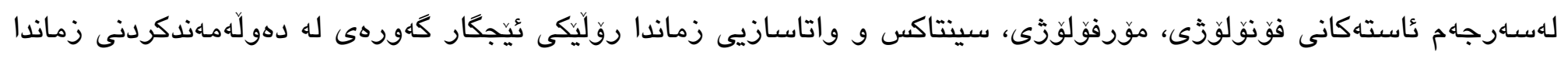

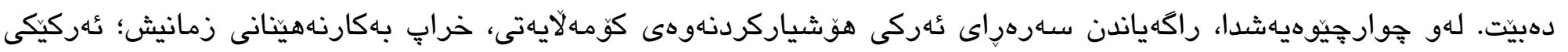

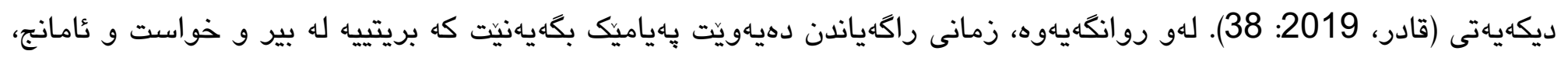

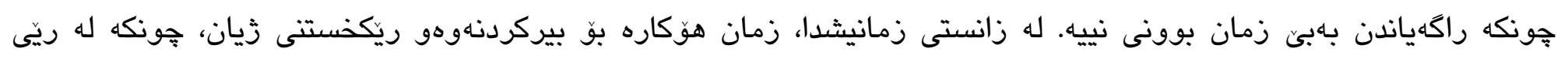

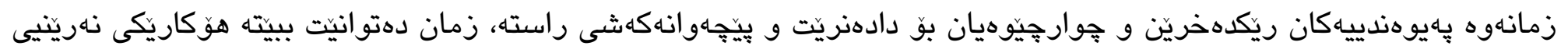

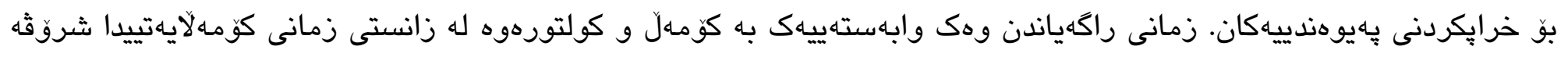

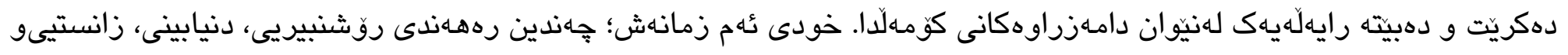

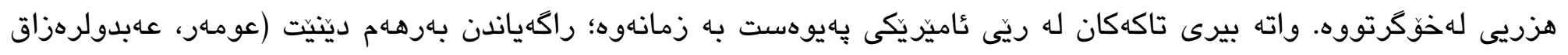

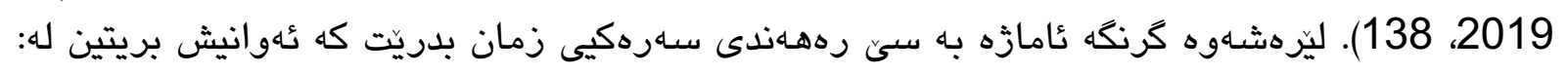

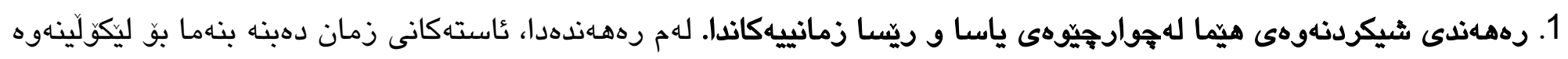
له بنهماكانى زمان.

2. رهههندى شيكردنهوهى هيما بهيوهست بهادنيابينييهوه. لهم رههـندهدا، دنيابينيى تاكهكان و جوّنيتى بيركردنهوهيان و ئهزموونيان

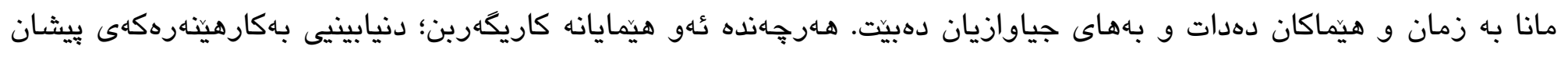

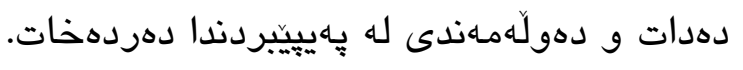

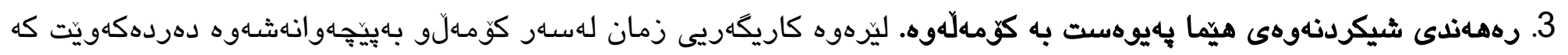

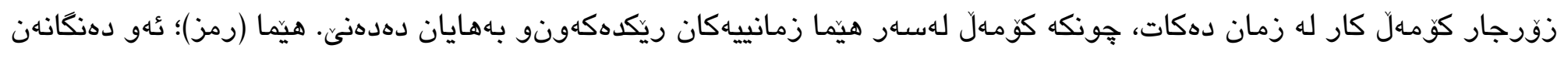

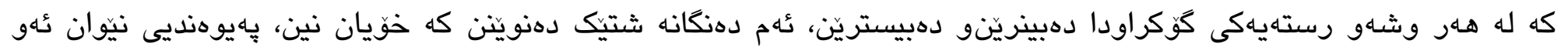

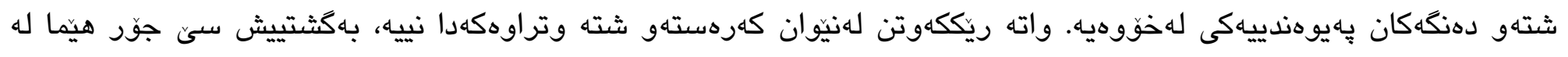

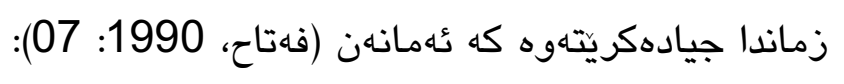




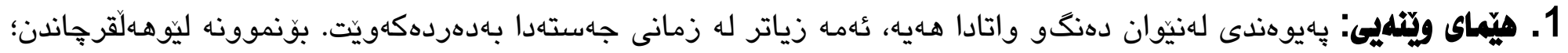
به ماناى نارازى بوونو تووريوبون ديّايت.

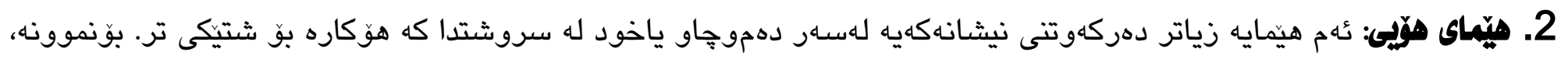

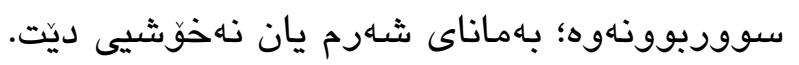

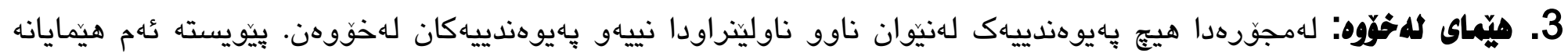

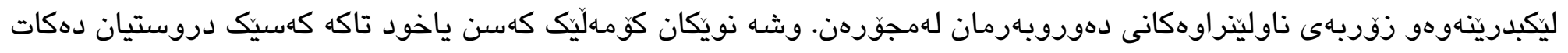

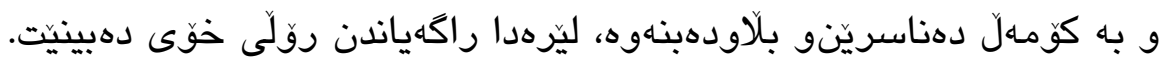

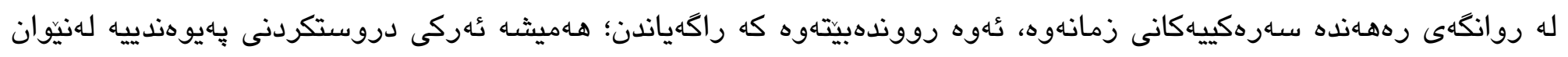

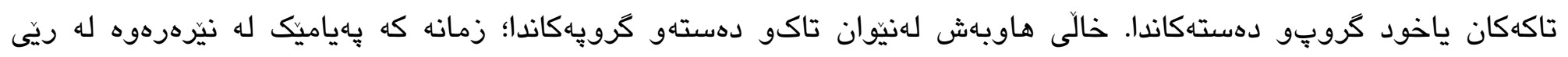

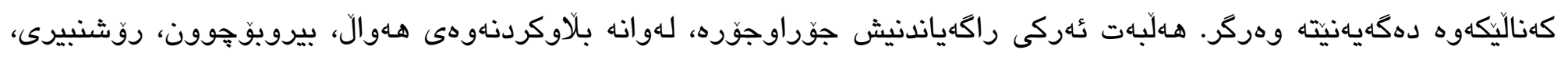

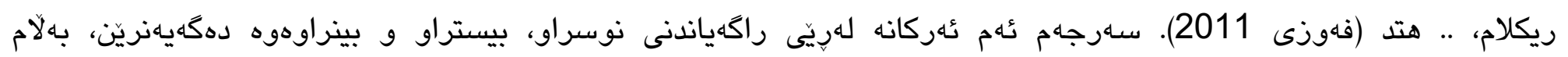

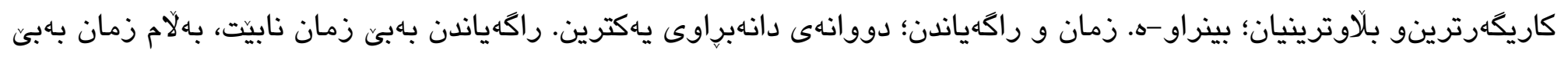

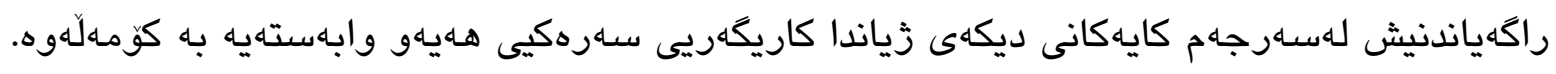

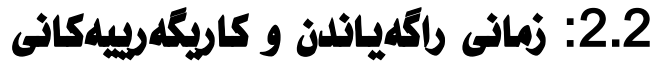

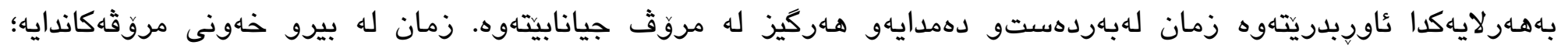

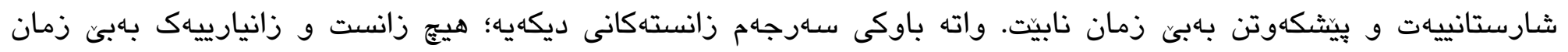

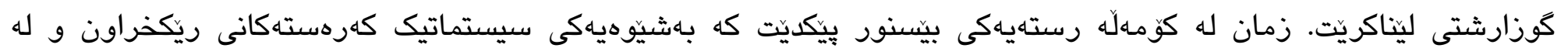

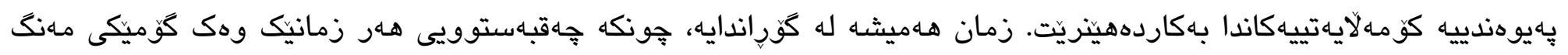

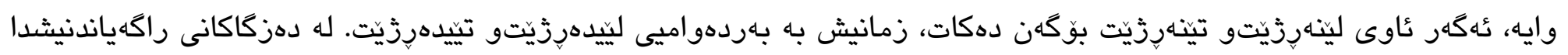

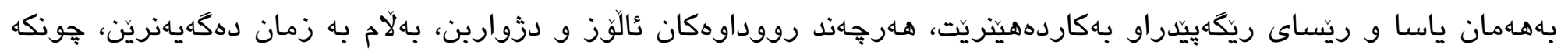

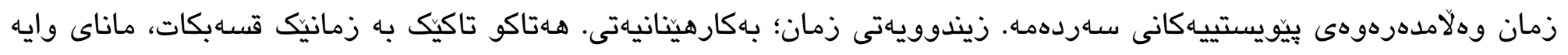

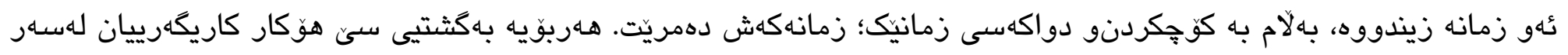

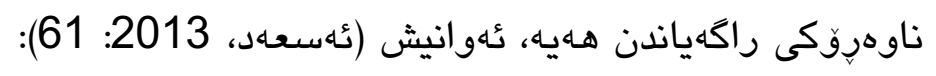

\section{جوَرو ناوهروكى راكهياندن}

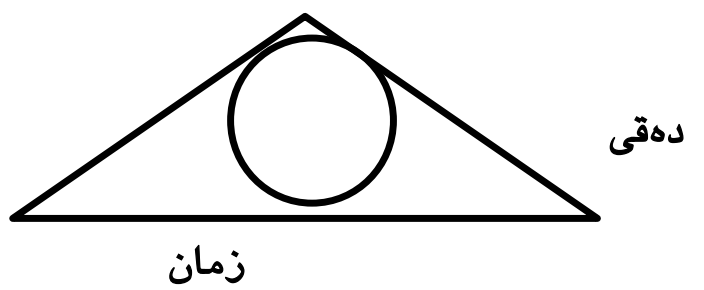

راكهياندن

زمان

وهركر 


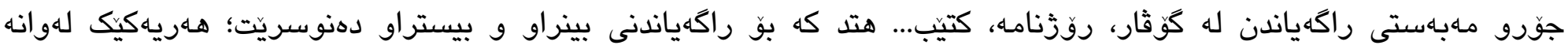

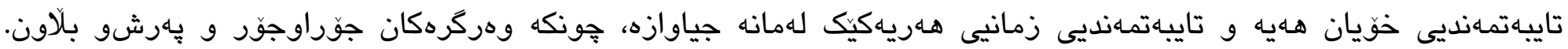

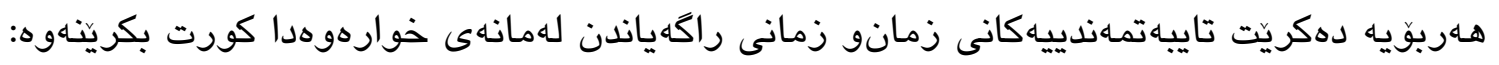

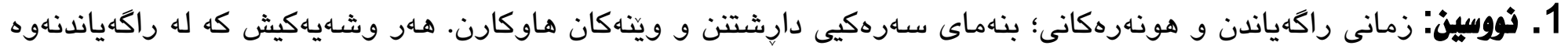

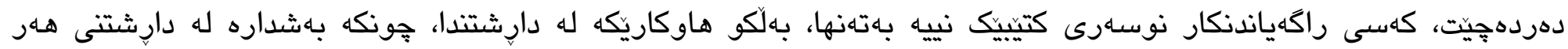

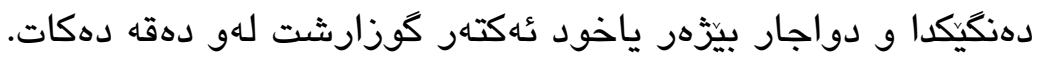

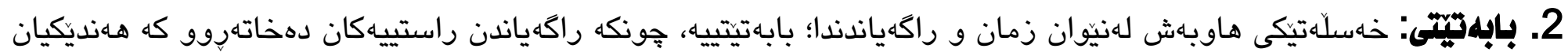

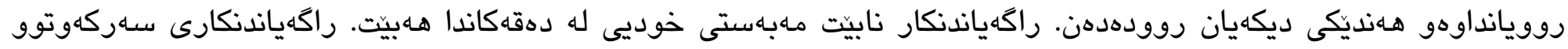

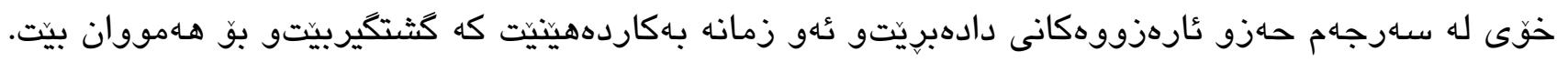

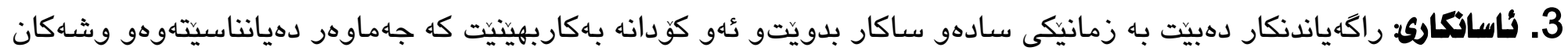
جوّراوجِربنو بركَهان كورت بن.

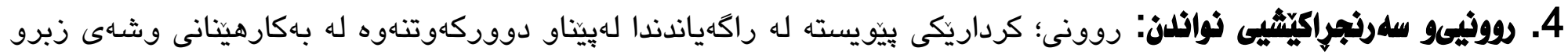

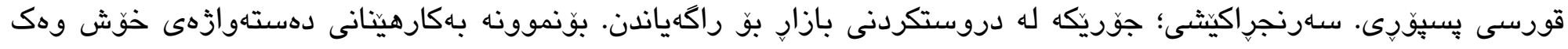

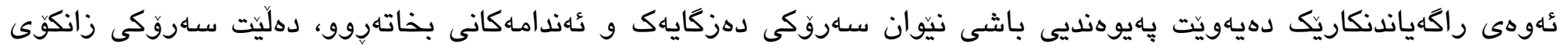

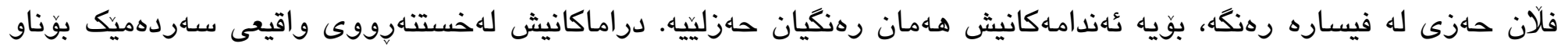

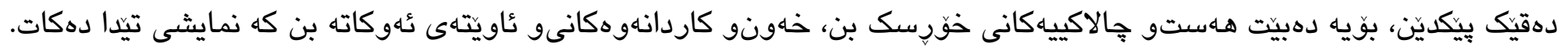

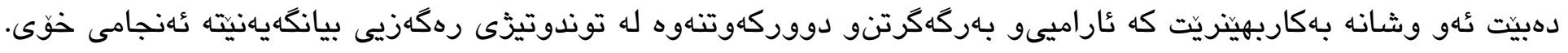

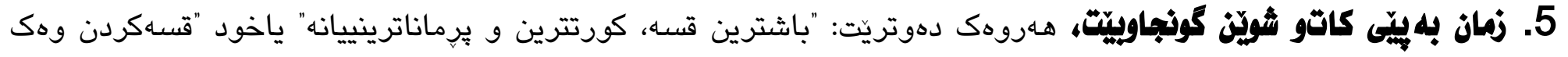

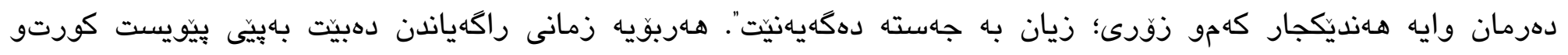

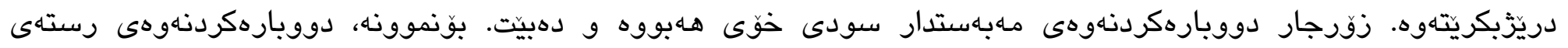

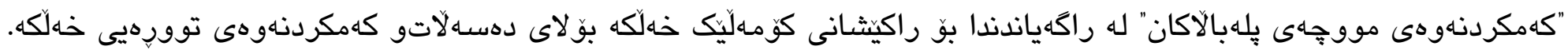

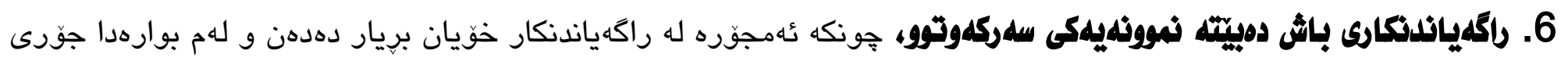

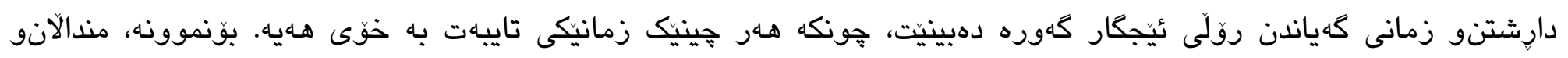

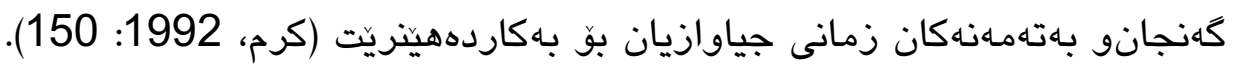

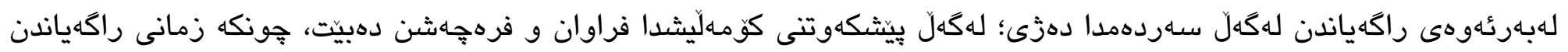

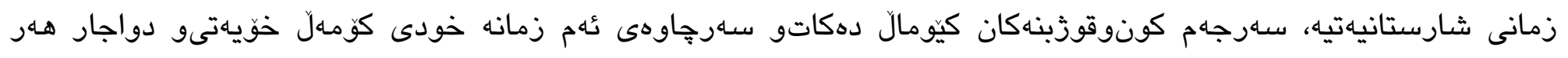

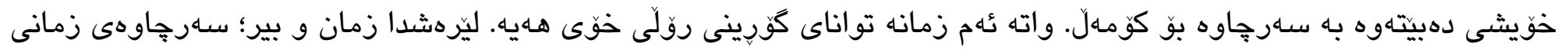

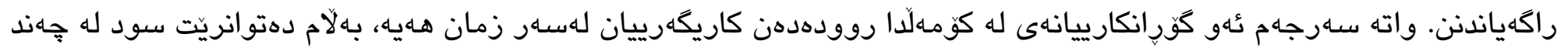

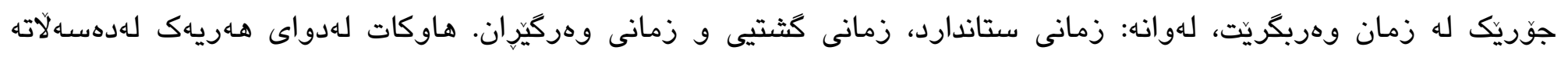

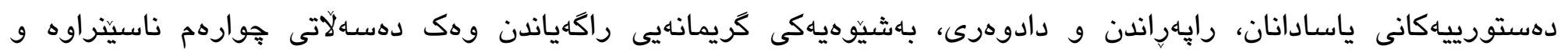




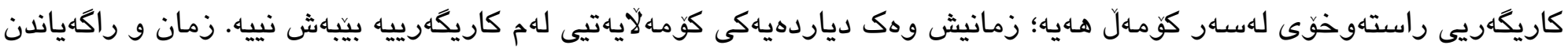

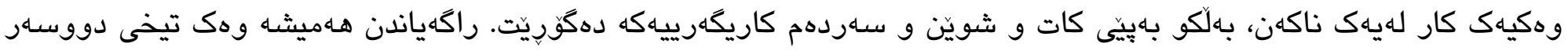

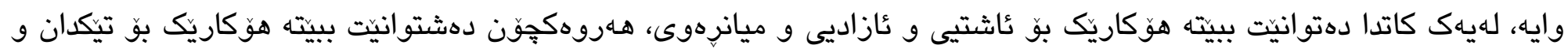

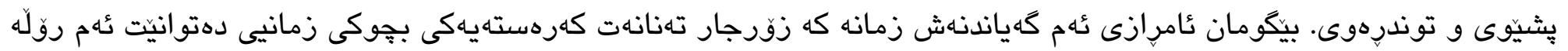

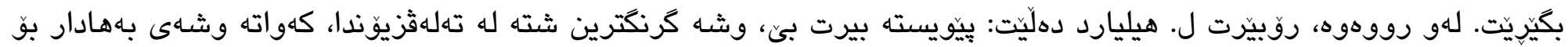

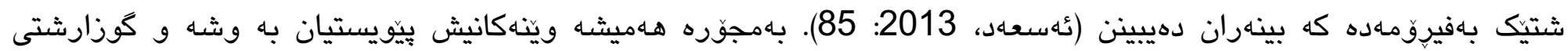

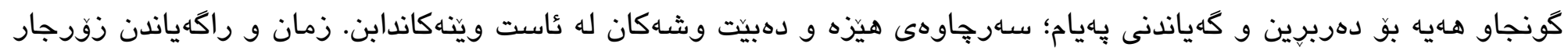

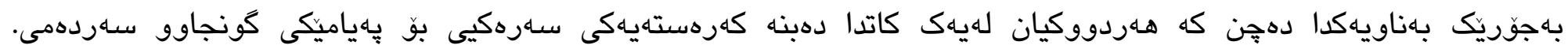

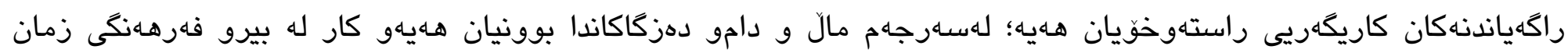

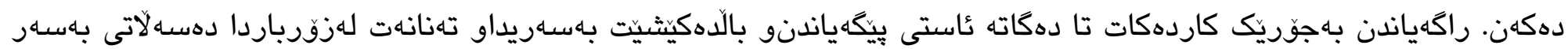

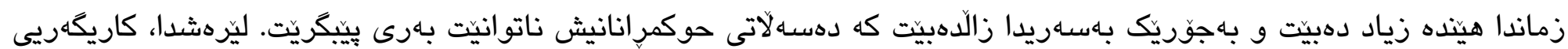
زمانى راكَياندن بـه دوو جوّر دهبيتي:

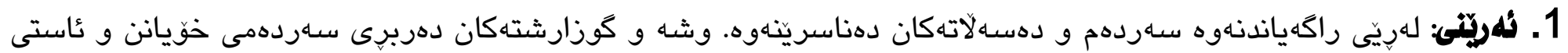

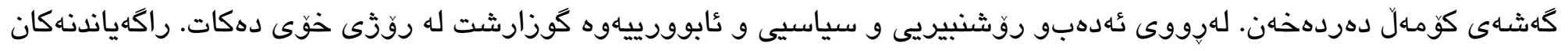

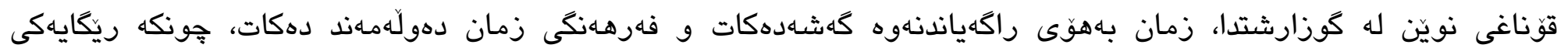

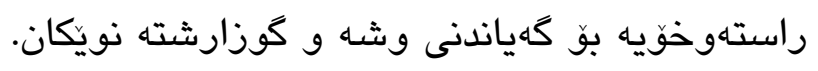

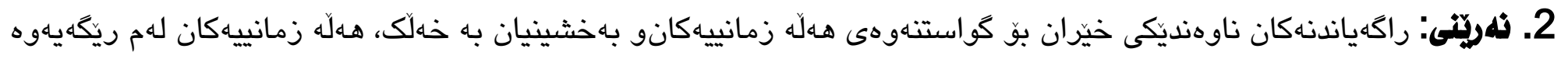

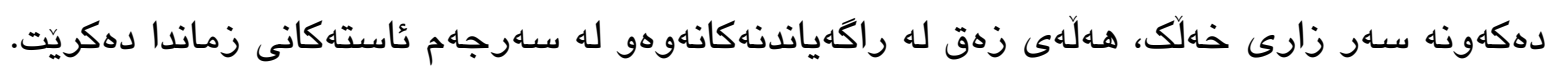

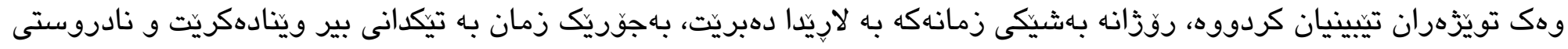

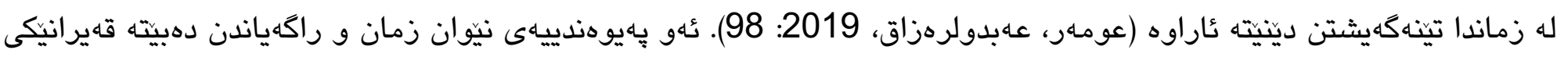

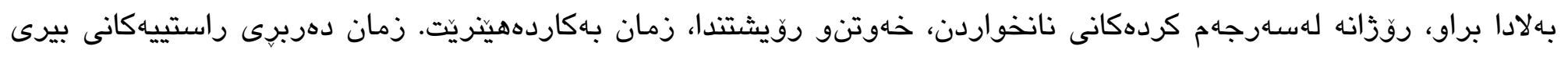

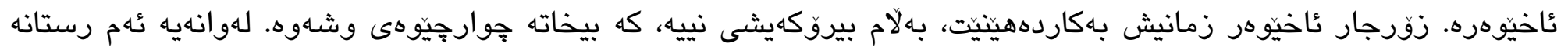

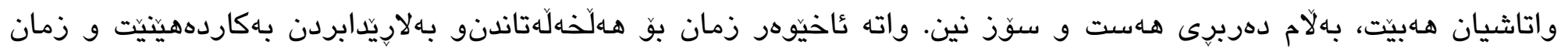

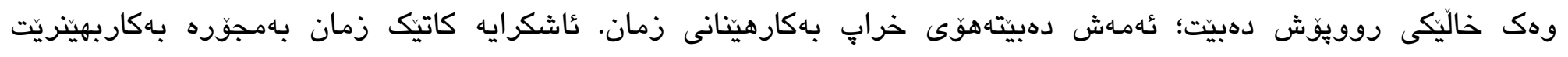

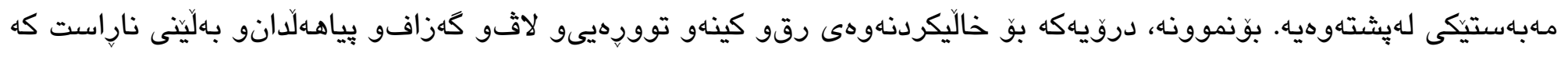

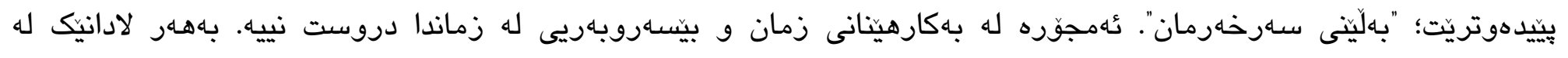

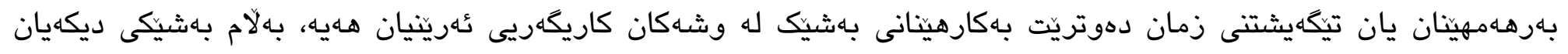

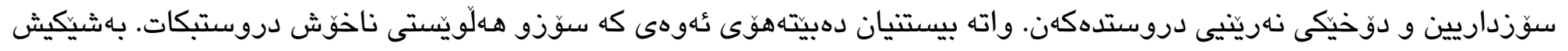

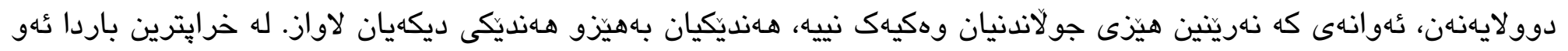

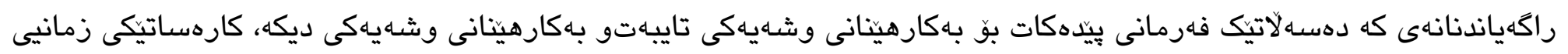

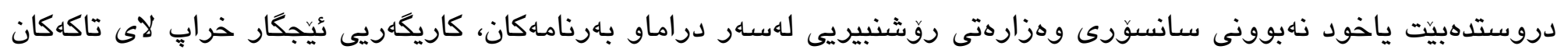
دروستدهكات. 


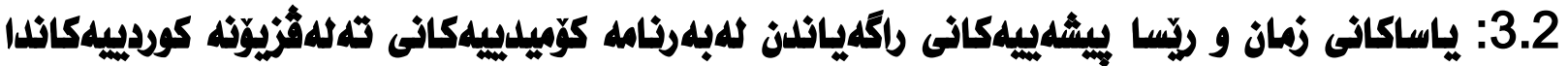

كئكَر ياساكانى زمان و ئاستهكانى؛ ئامانج لييان دروست بهكارهينانى زمان بيّت لهرووى نووسين و قسهكردنهوه، ئهوا ريّيسا

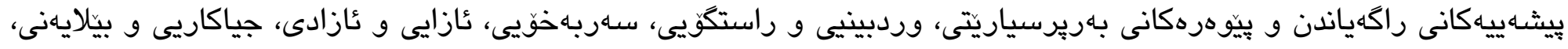

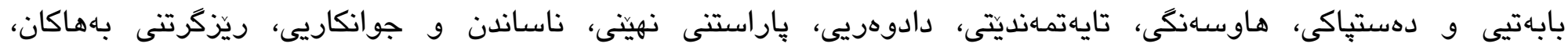

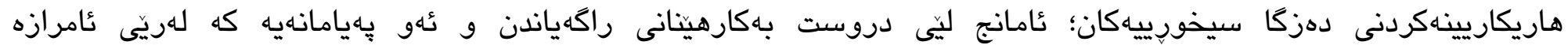

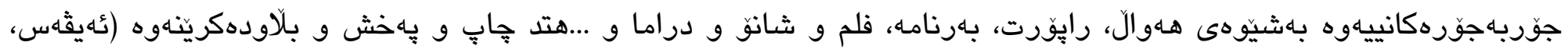
.103-71:2005

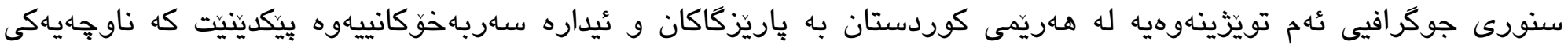

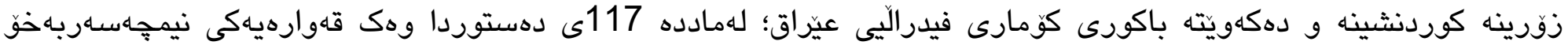

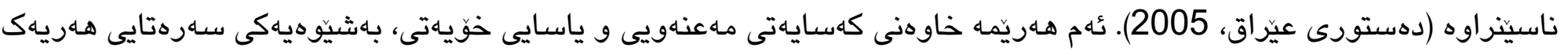

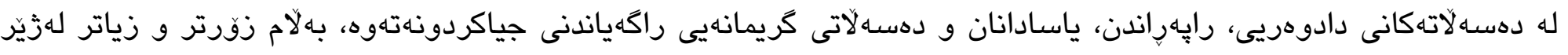

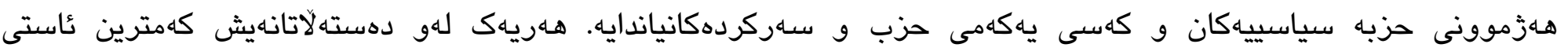

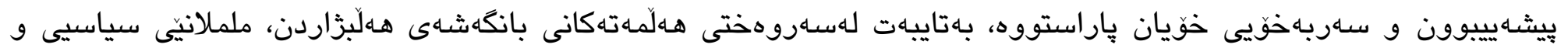
قهيرانه جورِيهجوَردكاندا (Aivas, 2017).

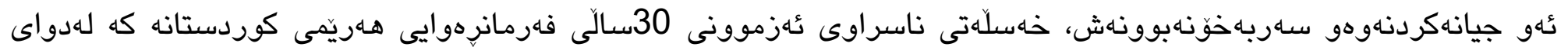

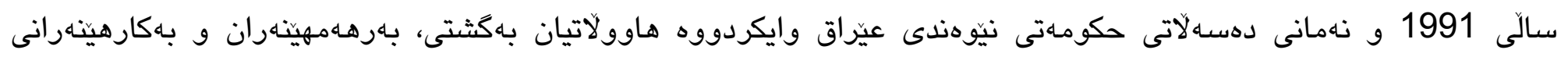

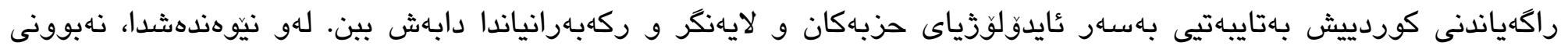

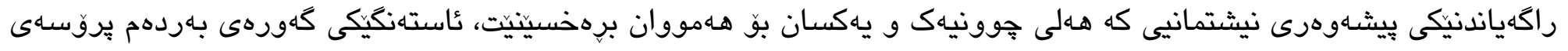

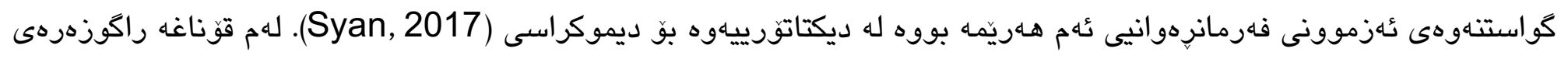

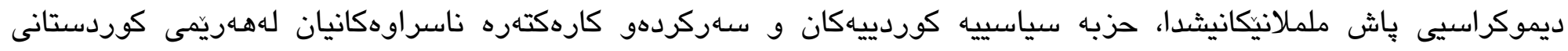

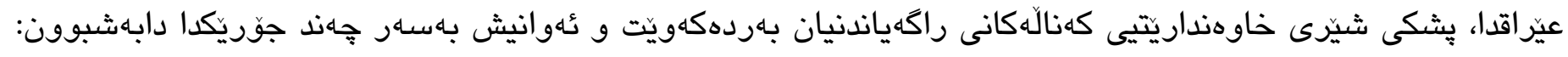

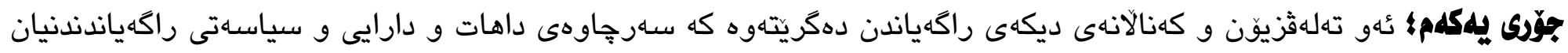

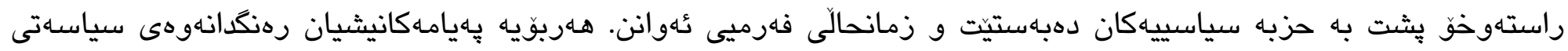

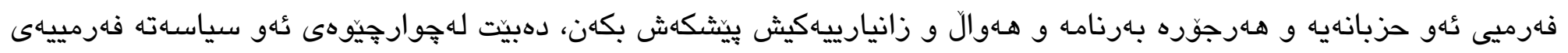

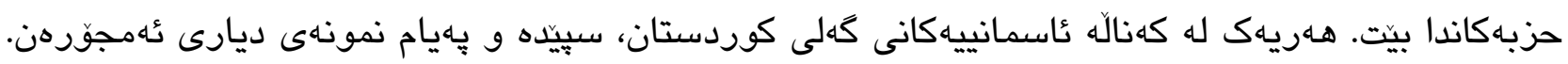

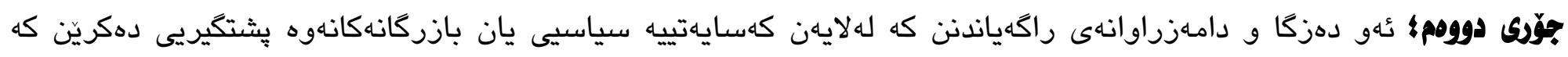

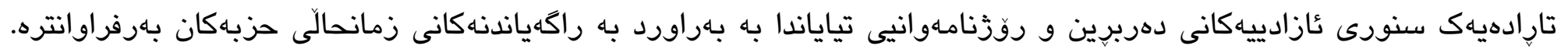

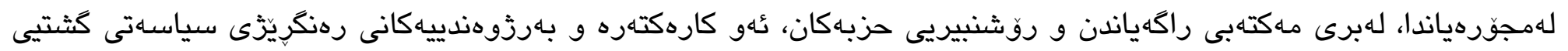

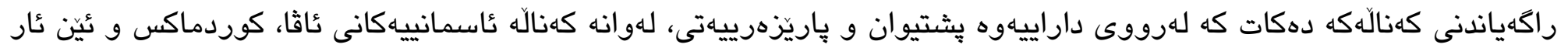




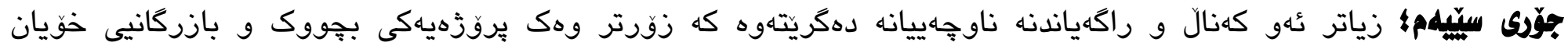

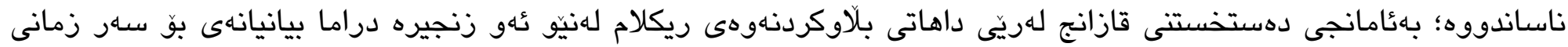

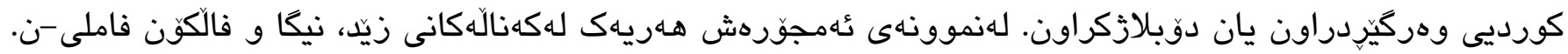

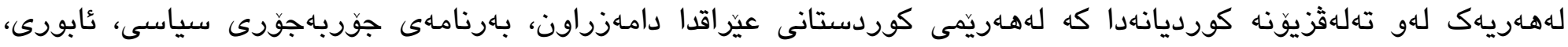

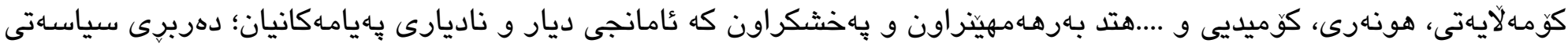

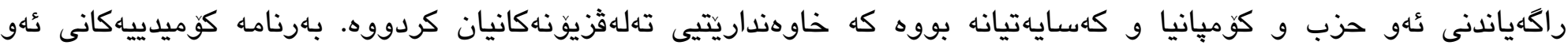

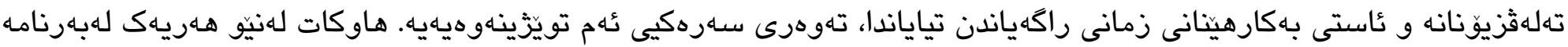

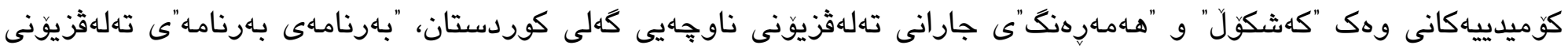

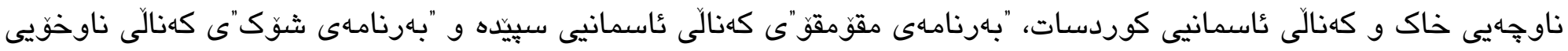

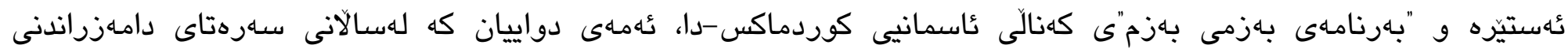

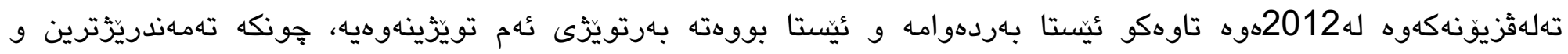
بينراوترينيانه.

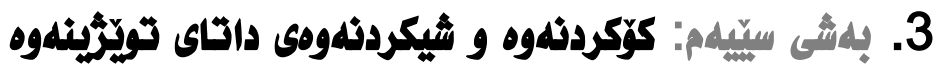

لهم بهشهداو لهرووى كردهييهوه، سهرجهم ئهو ريكاريانهى بو كوكردنهوهى داتاى تويّزينهوهكه و شيكردنهوهى ئهنجامهكان

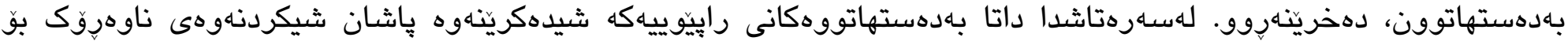

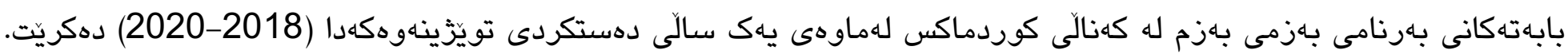

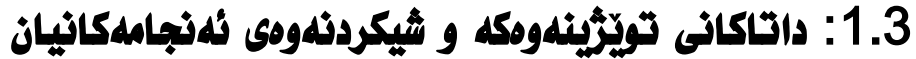

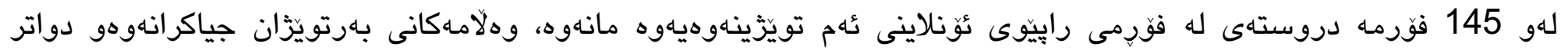
بهشيّوهيهى خواردوه داتاكانيان شيكرانهوه. 
خشتهى زُماره 05: كوردماكس؛ وهك كهناليَكى خوَشبارى (ترفيهى)

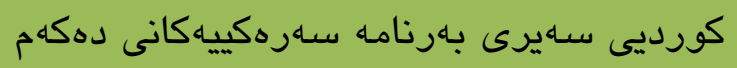

خشتهى زماره 05، ئهو بِّجوونه دووياتدهكاتهوه كه

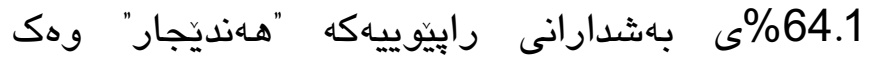

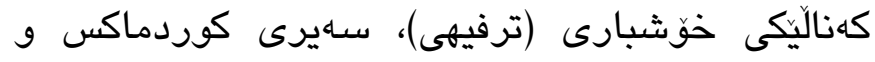
بهارنامه سهرهكييهكانى دهكهن.

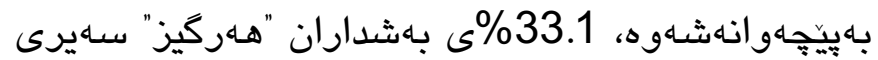

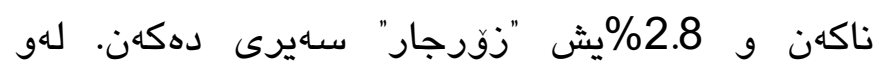

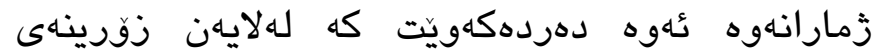

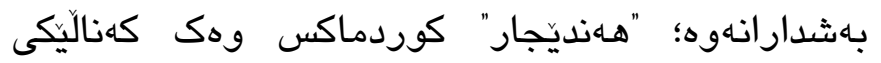

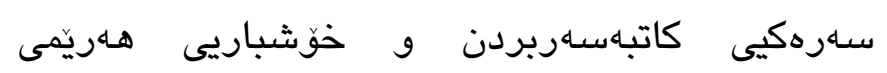

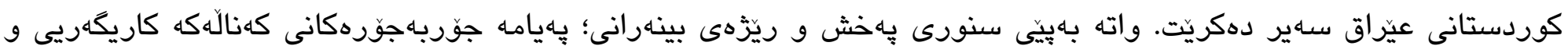

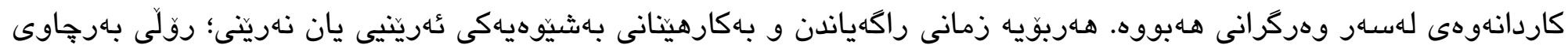

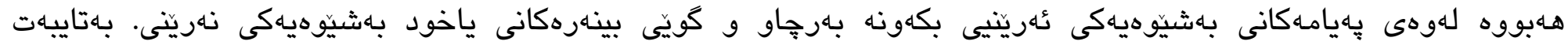

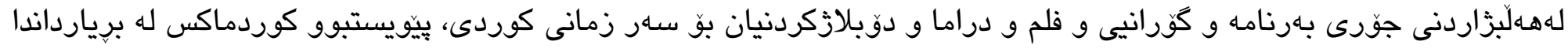

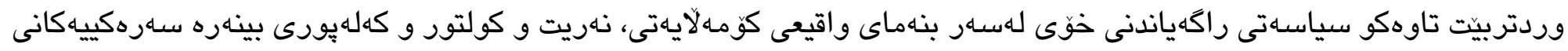

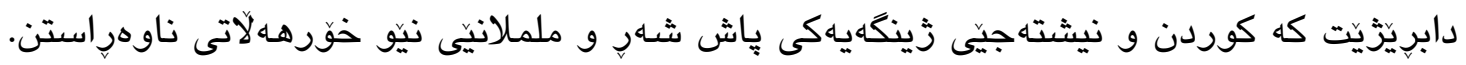

\subsection{3: بلهزمى بلهزم له كوردماكس ومك بالثترين بلهرنامهى كوميدى}

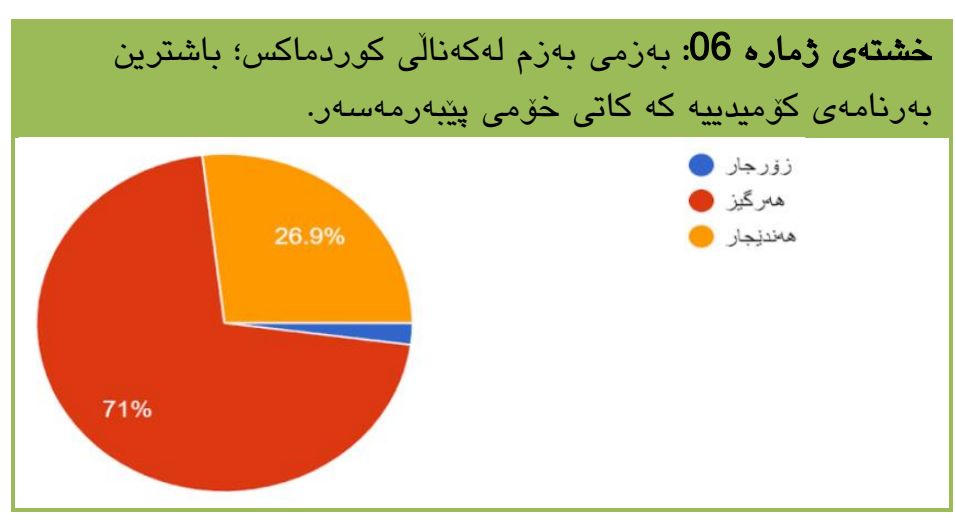

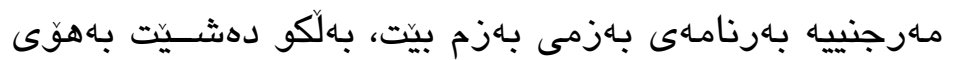

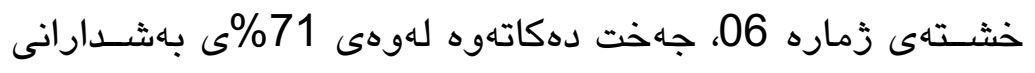

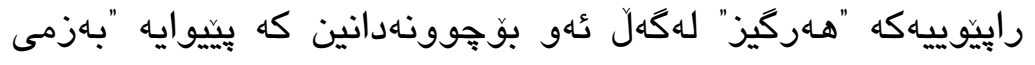

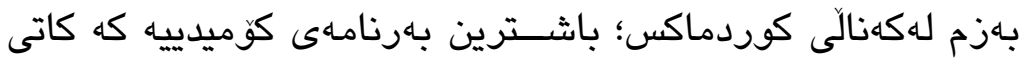

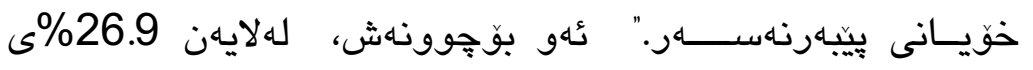

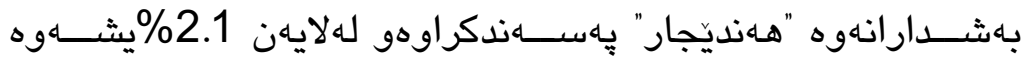

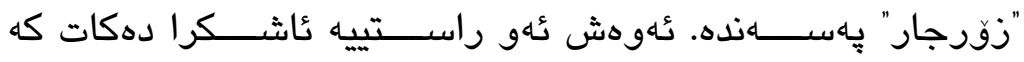

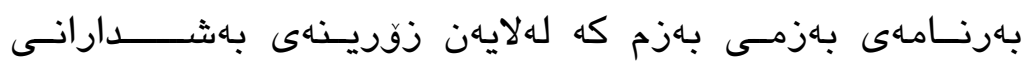

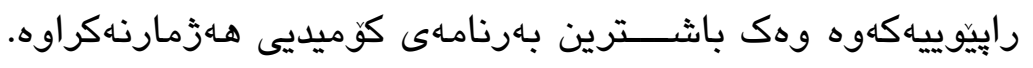

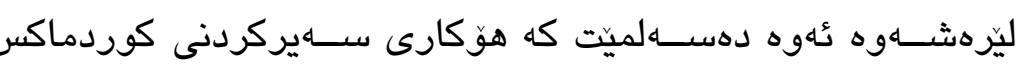

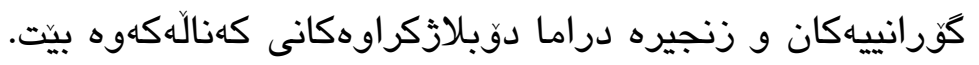




\subsection{3: بلهرنامهى بلهزمى بلهزم و واقيعى كومهه لكلهى كوردى}

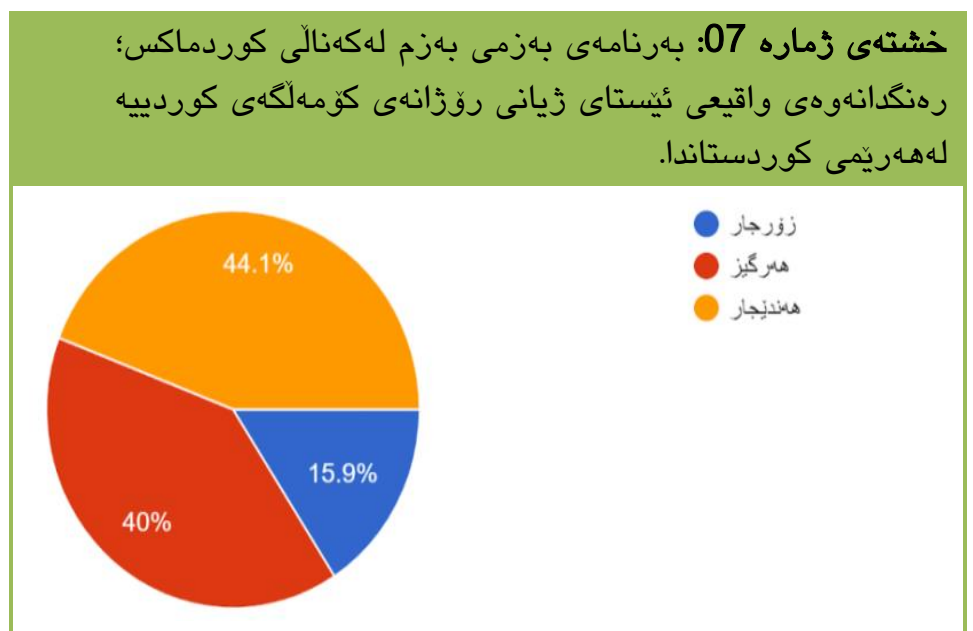

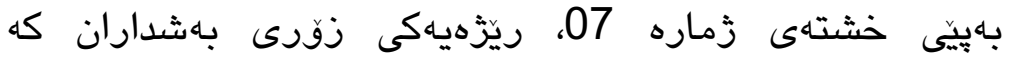

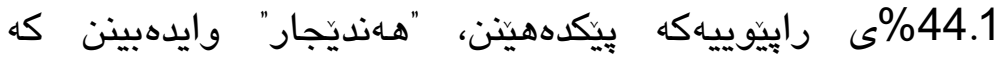

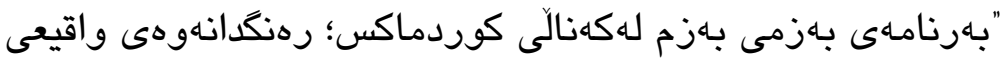

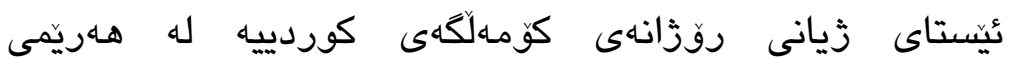

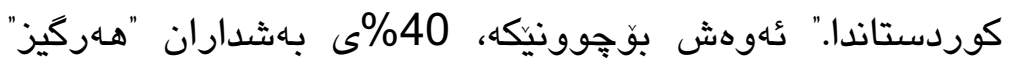

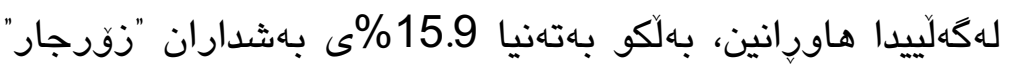

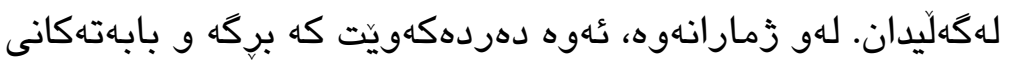

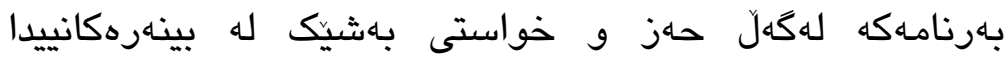

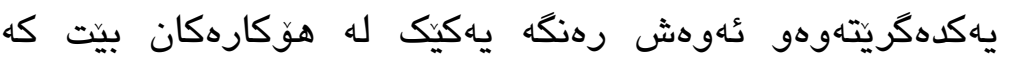
وايكردووه بييته دلخوازى بهشيكى زوّر له وهركران.

\section{4:1.3: بلدرنامهى بلةزمى بلهزم و ناوزياتلنى كلس و كرويلدكان}

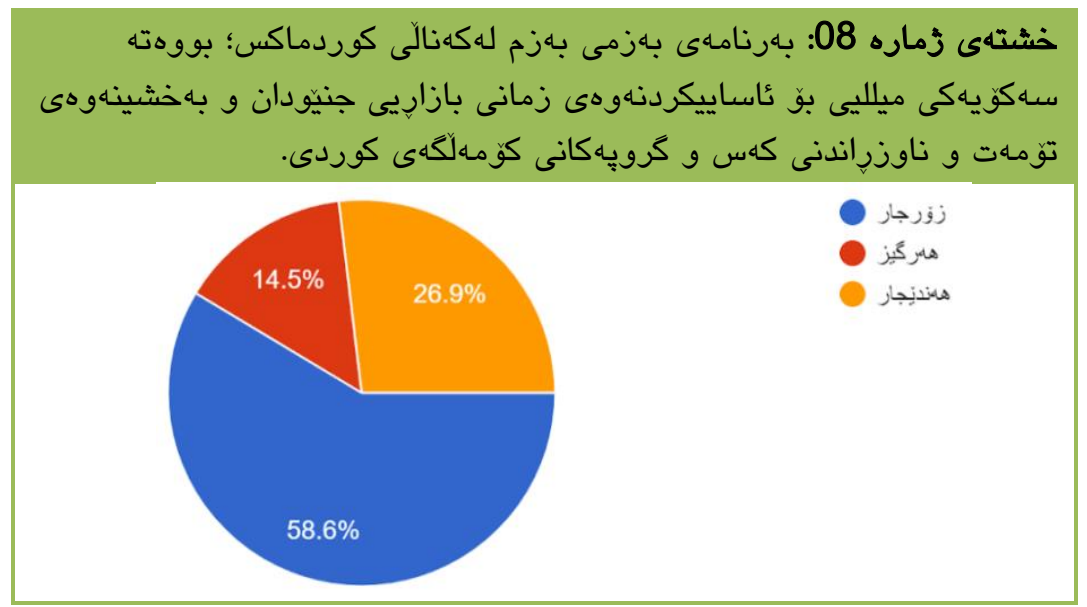

خشتهى زماره 08، ئهوه نيشان دهدات كه 58.6\%

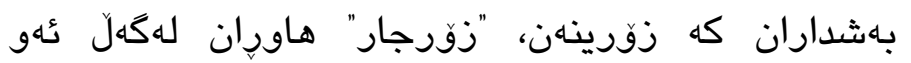

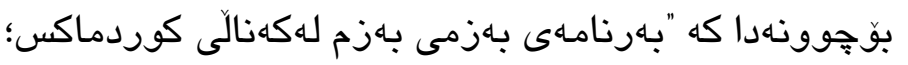

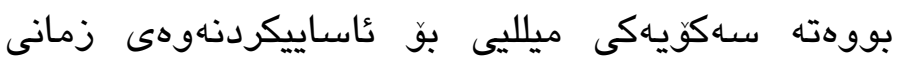

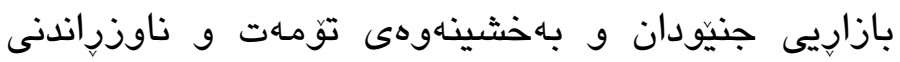

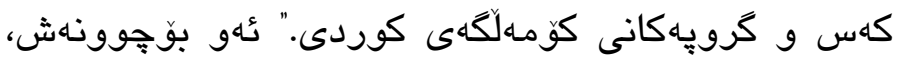

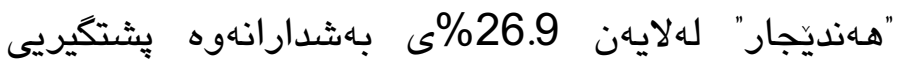

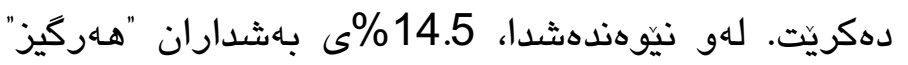

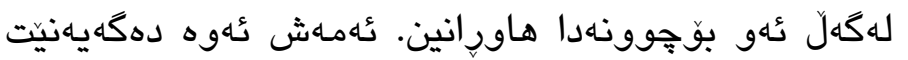

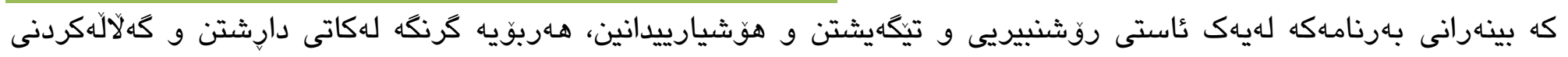

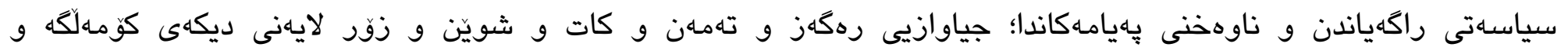

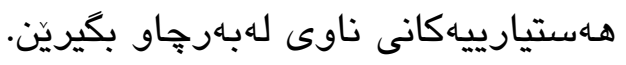




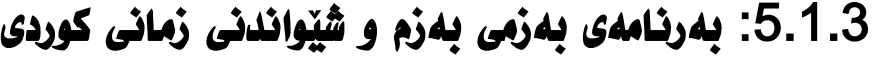

خشتهى زماره 09: بهرنامهى بهزمى بهزم له كهنالى كوردماكس؛

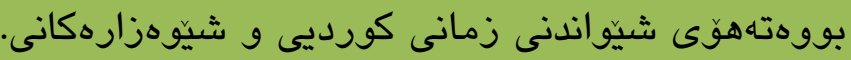

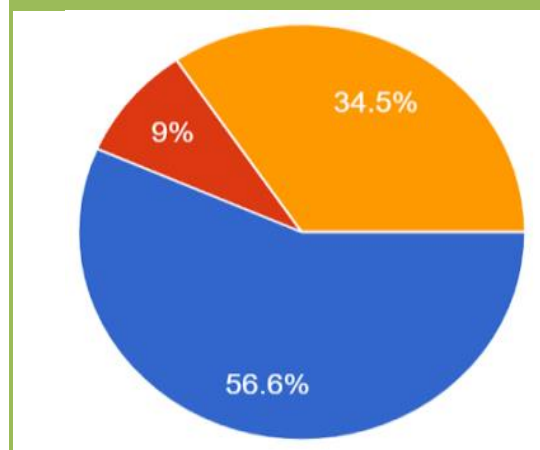

شيّوهزارهكانيدا بيّت، بهتايبهت لهئاستى وشهسازيى و رستهازيى و
بهايِي خشتهى زماره 09، زقرينهى بهشداران كه دهكاته

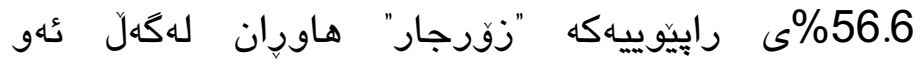

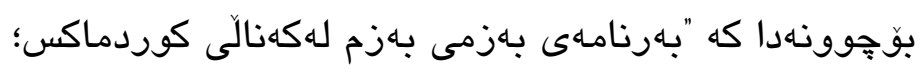

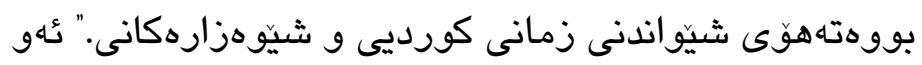

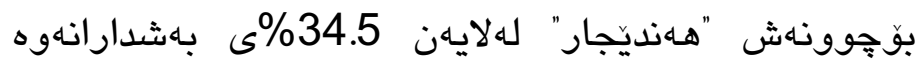

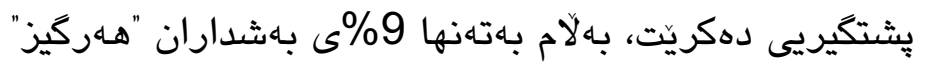

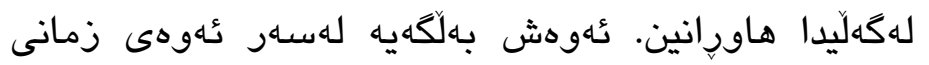

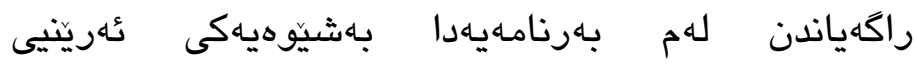

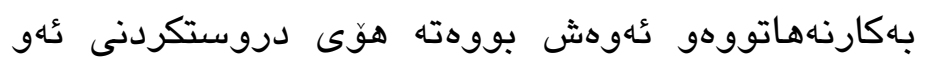

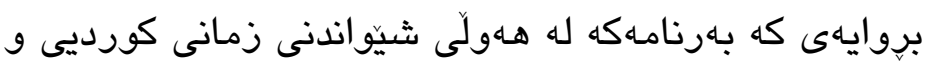

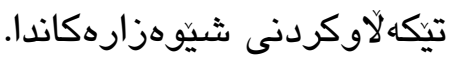

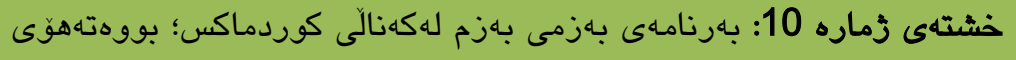

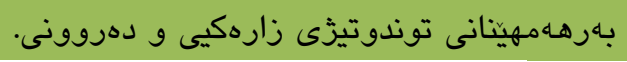

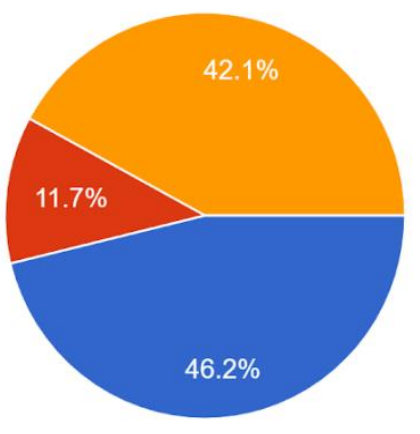

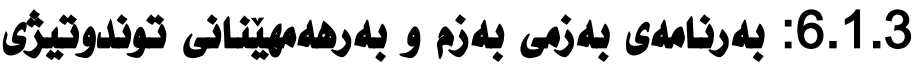

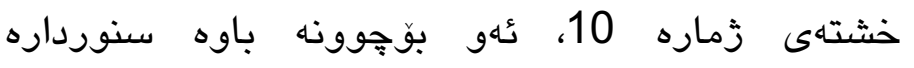

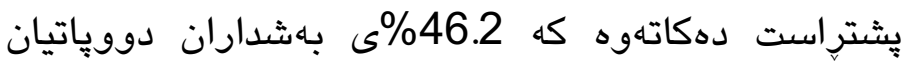

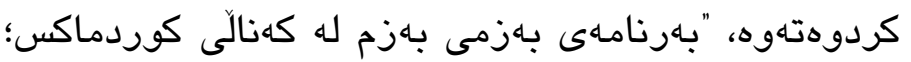

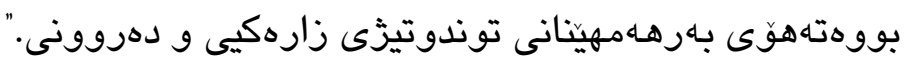

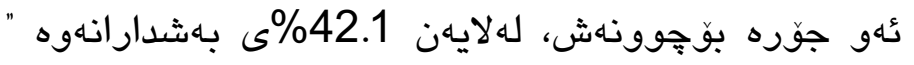

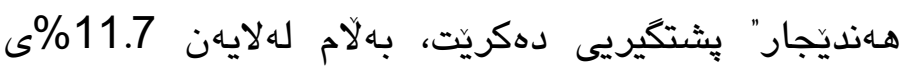

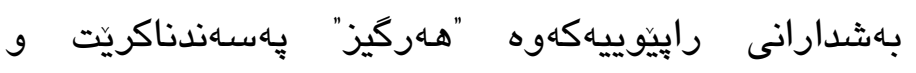

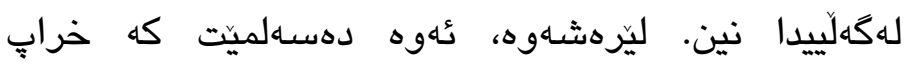

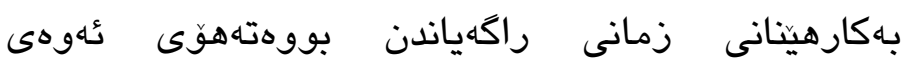

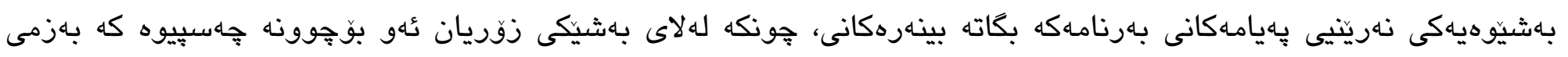

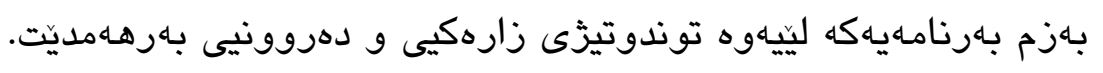




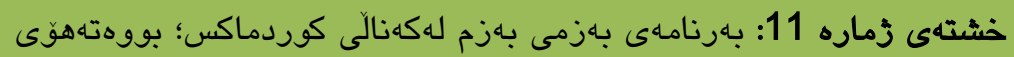

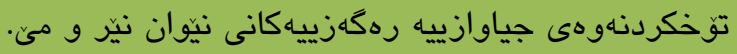

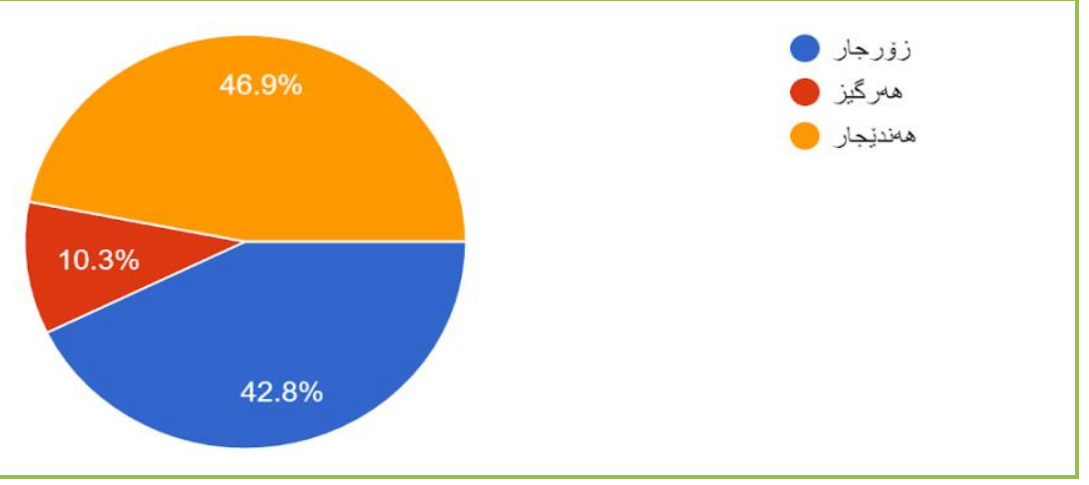

لهخشتهى زماره 11دا، ئهوه دهردهكهويتيت كه 46.9\%ى

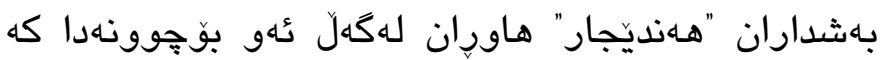

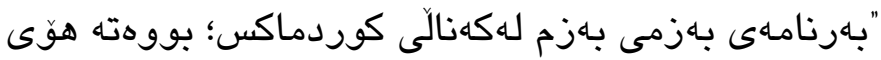

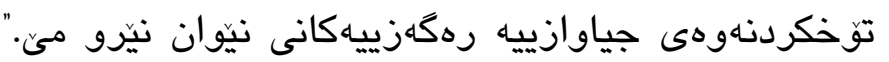

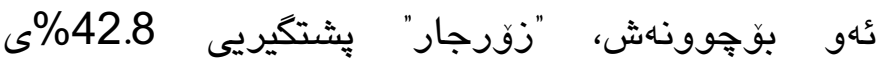

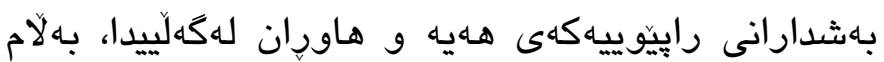

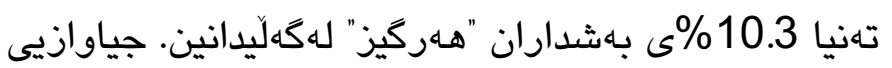

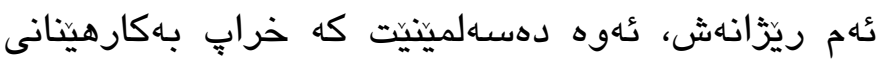

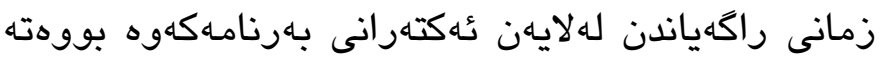

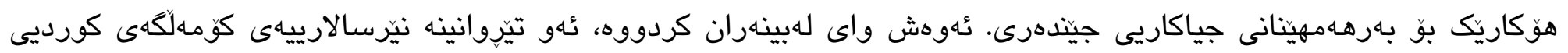

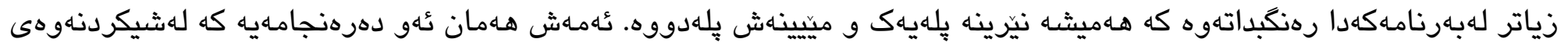

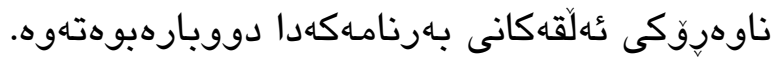

\subsection{3: بلهرنامهى بلهمى بلهم و تيكلدانى زموق و سليقهى بينهران}

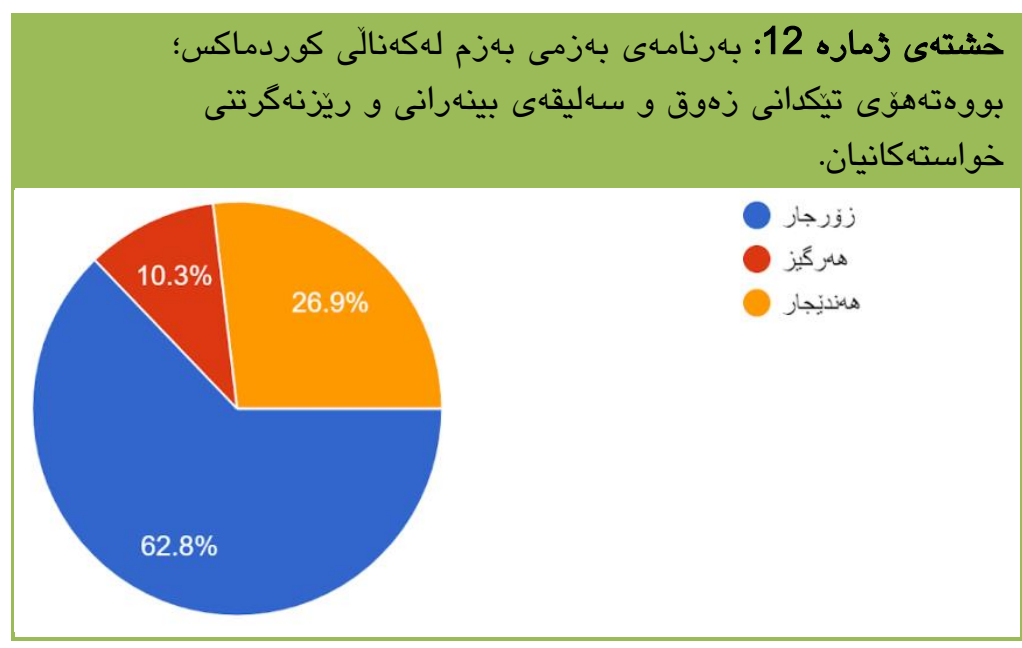

خشتهى زماره 12، ئهوه يشتراست دهكاتهوه كه 62.8\%

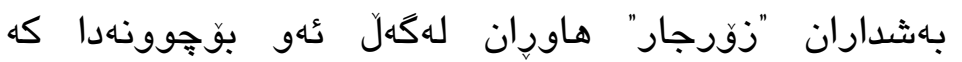

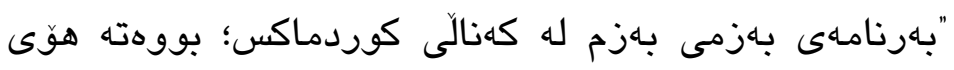

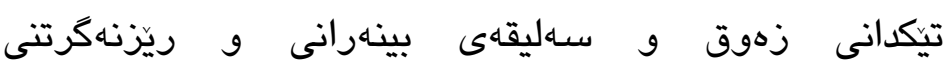

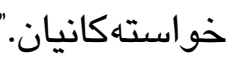

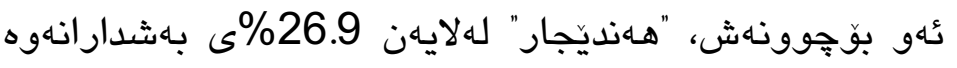

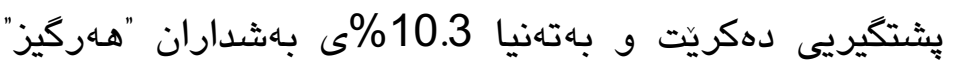

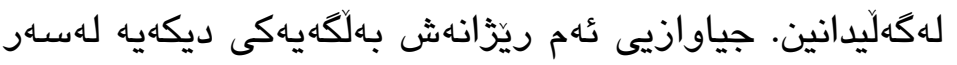

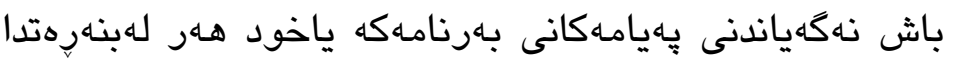

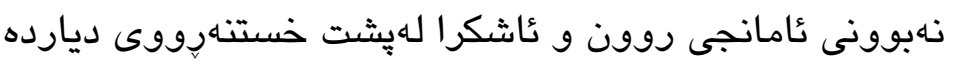

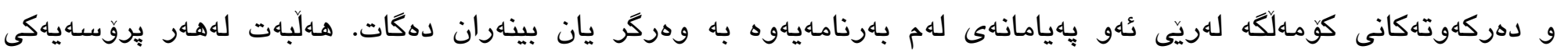

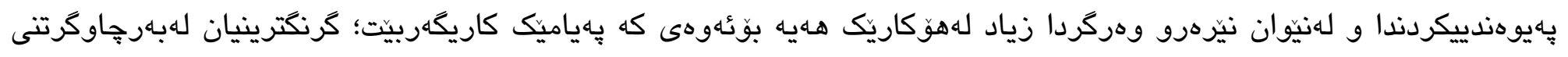

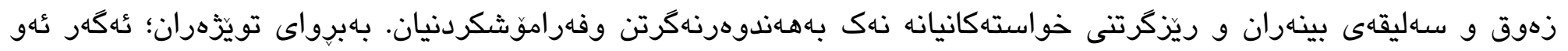

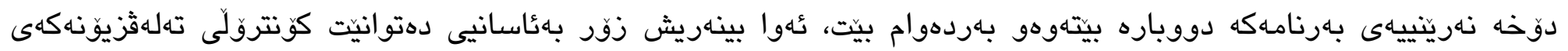




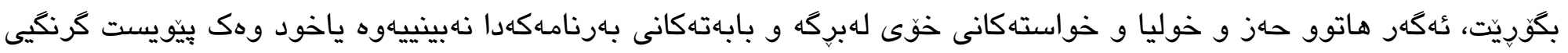
بينّهدرا.

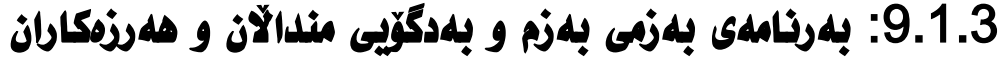

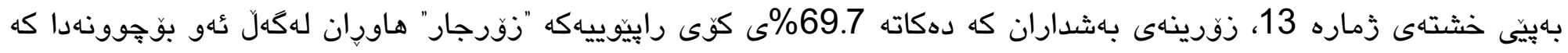

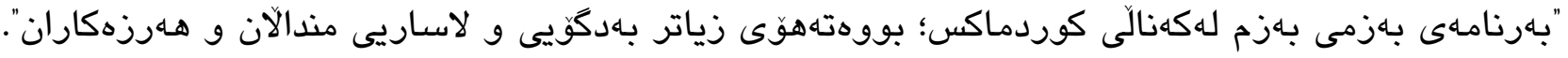

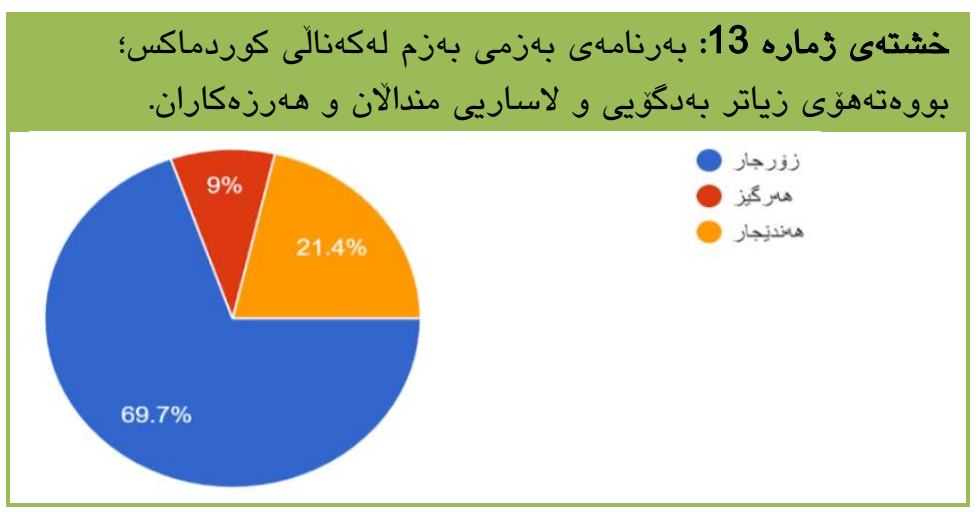

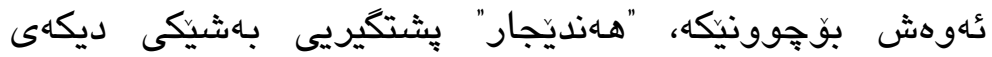

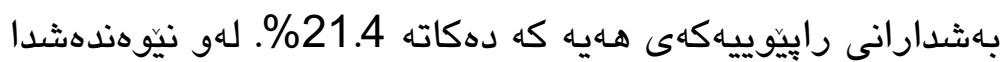

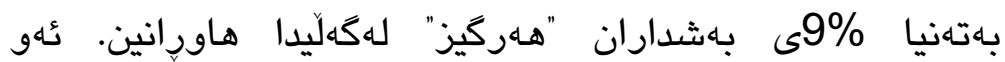

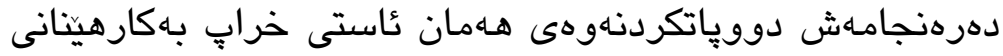

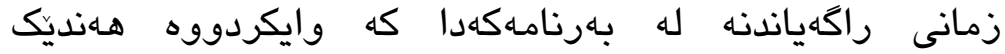

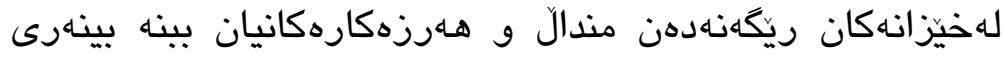

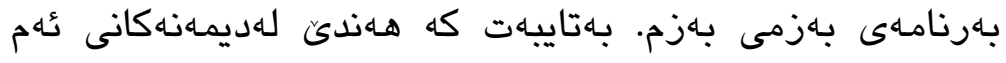

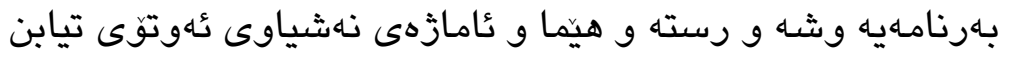

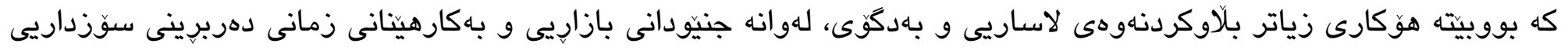

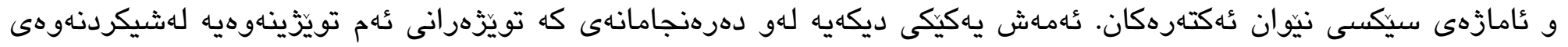

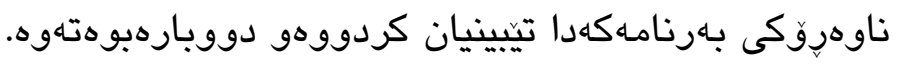

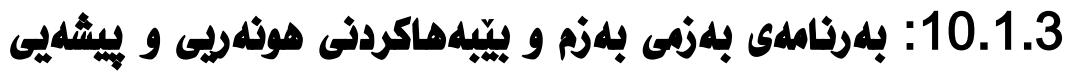

خشتهى زماره 14: بهارنامهى بهزمى بهزم له كهنالى كوردماكس؛

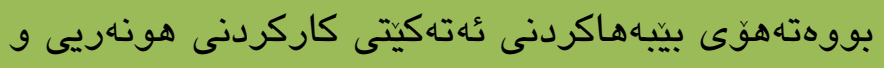

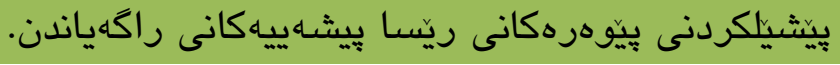

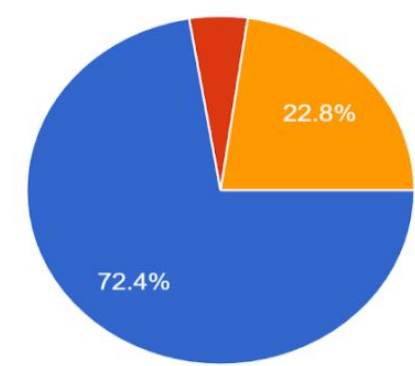

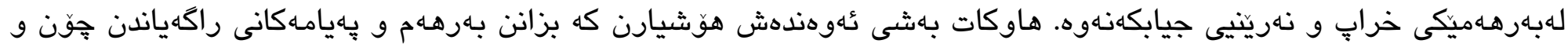

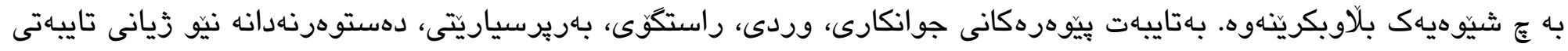

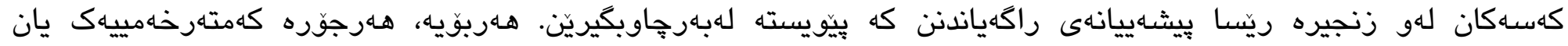

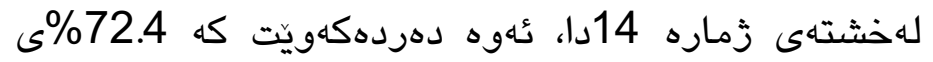

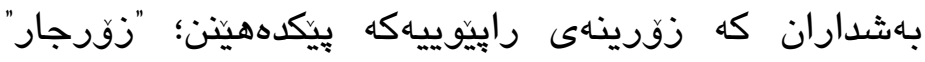

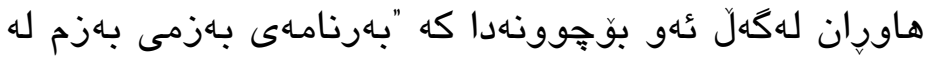

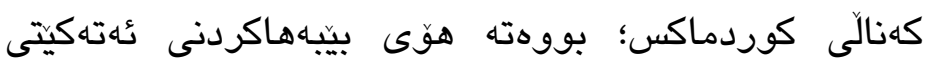

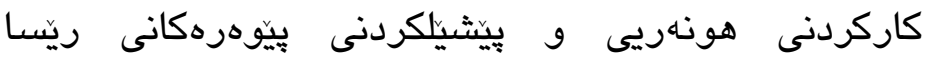

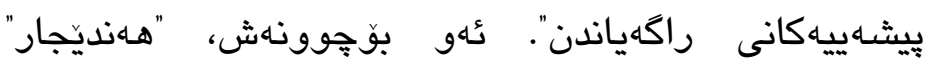

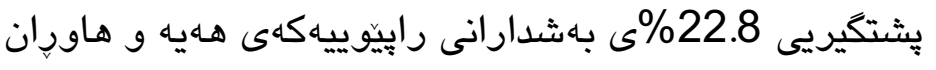

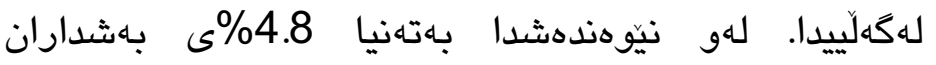

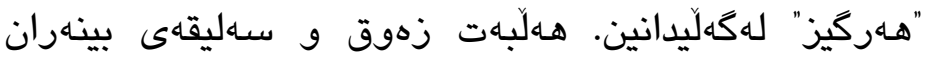

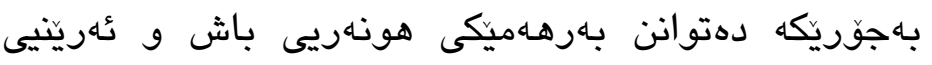




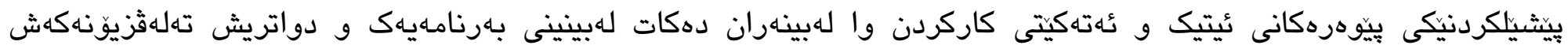

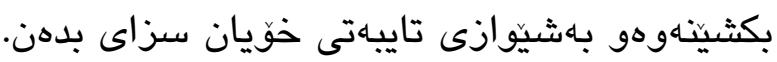

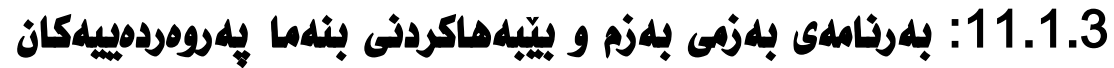

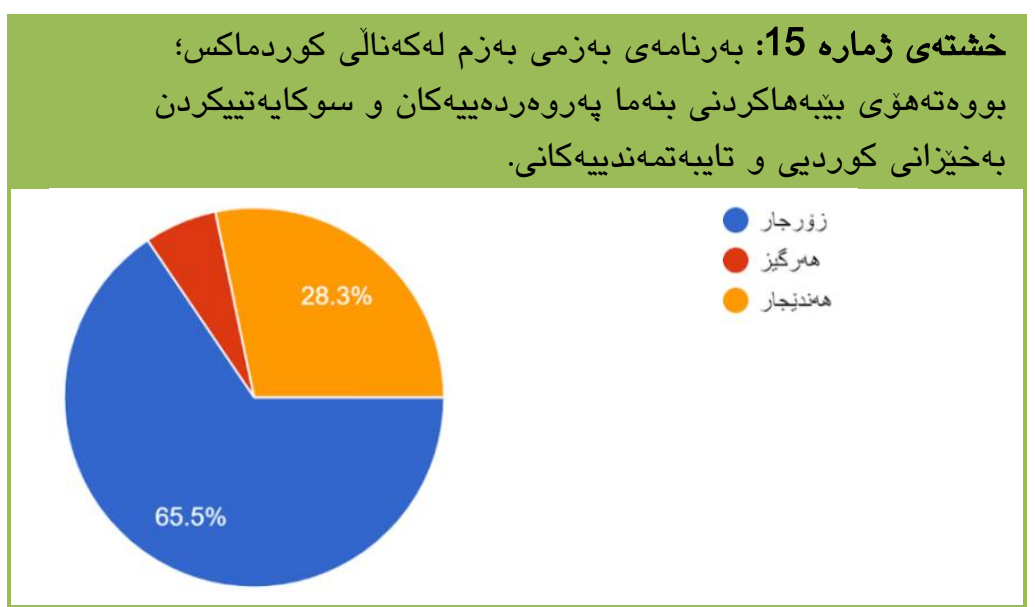

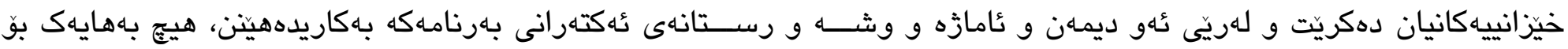

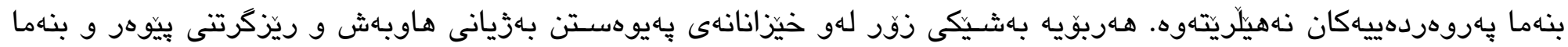

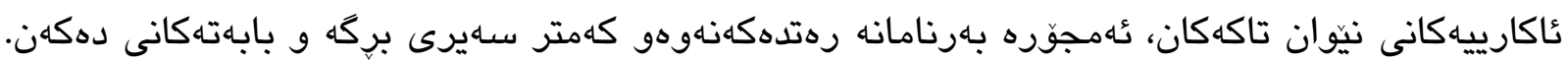

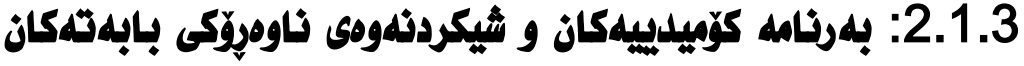

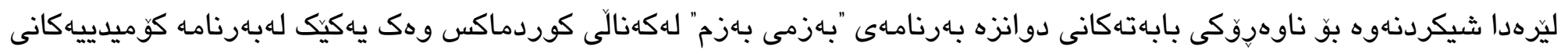

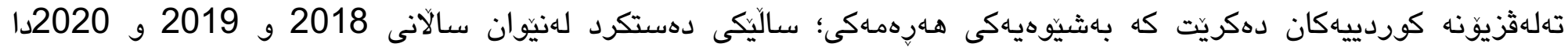

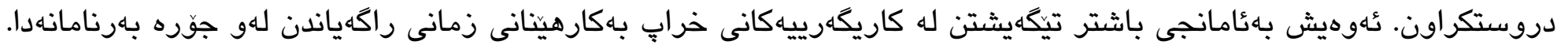

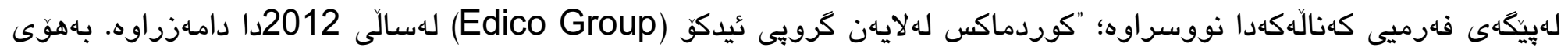

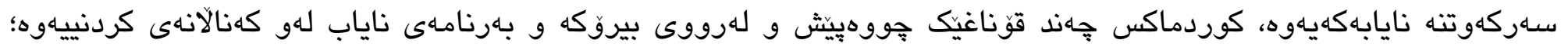

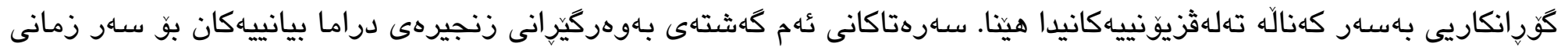

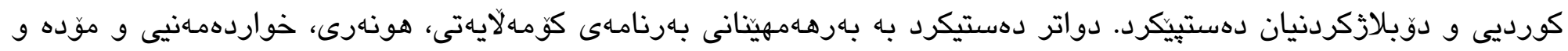

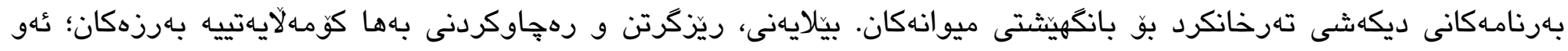

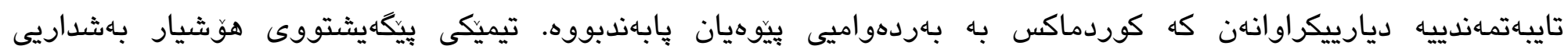

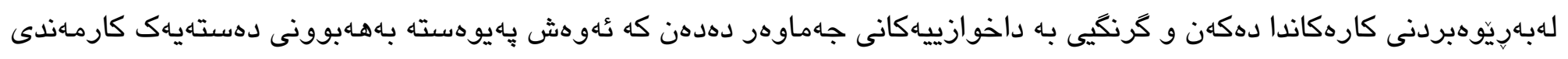

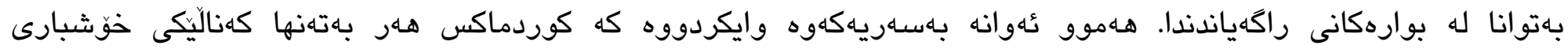

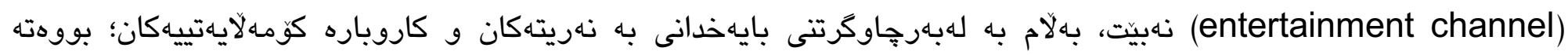

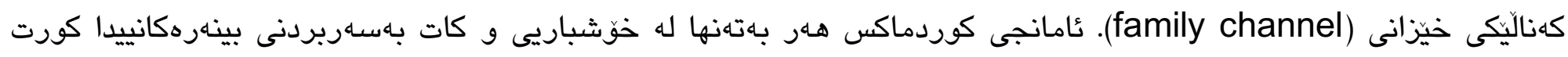

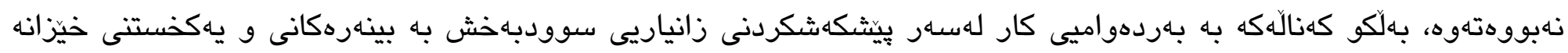




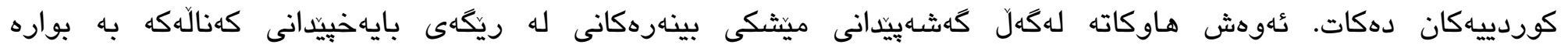

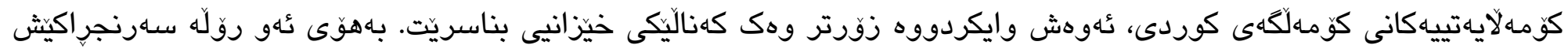

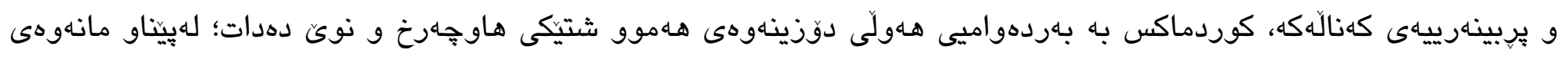

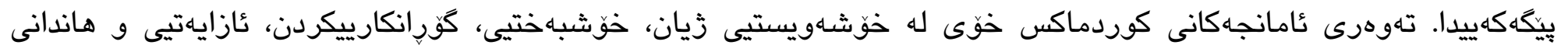

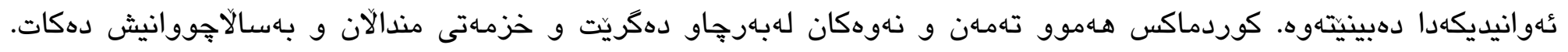

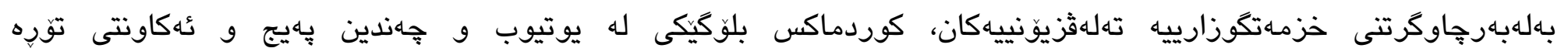

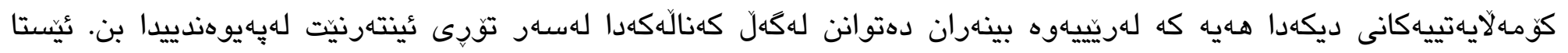

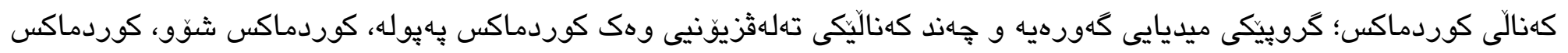

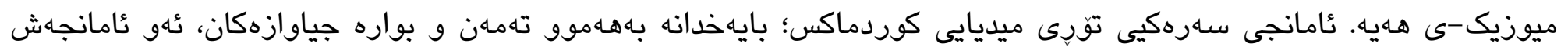

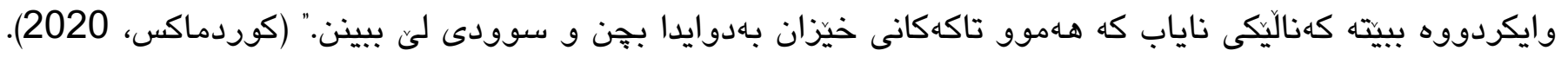

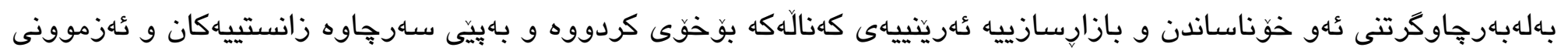

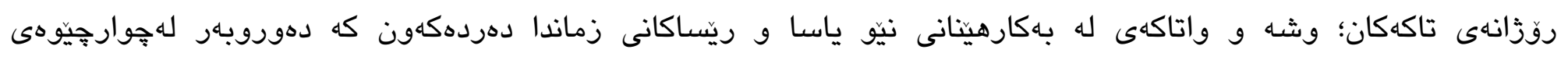

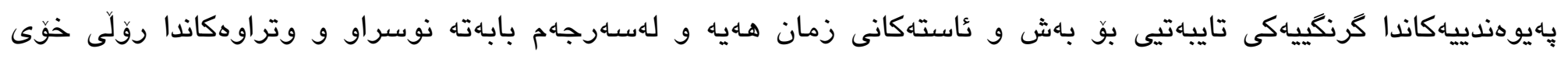

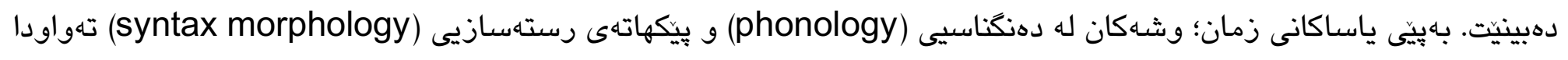

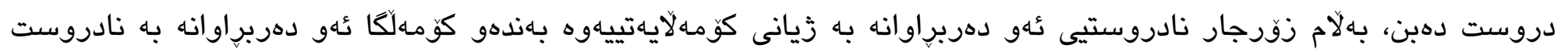

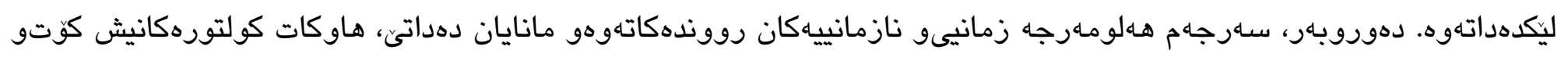

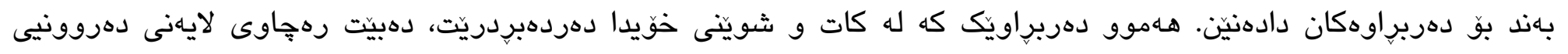

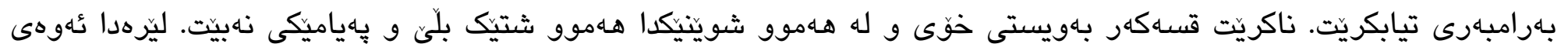

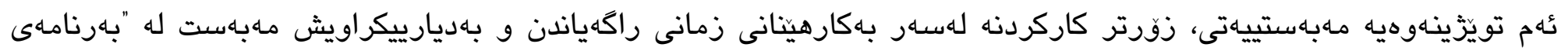

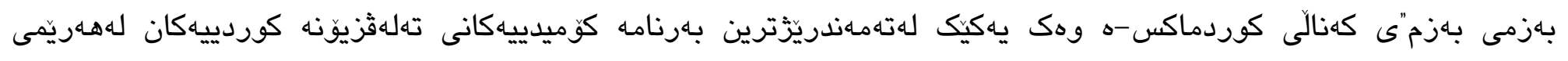

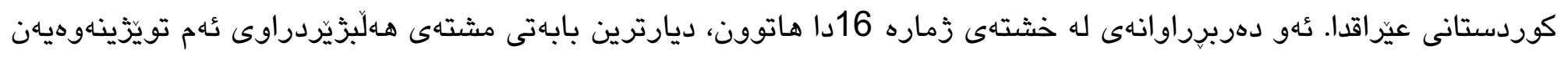

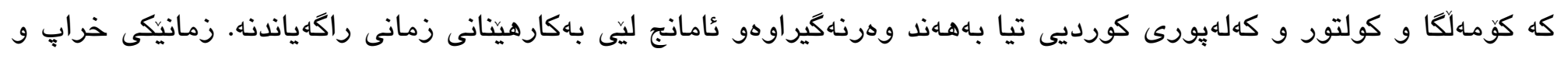

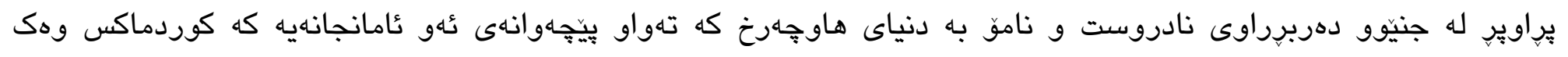

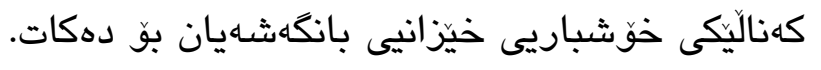

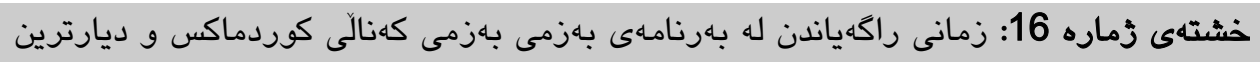

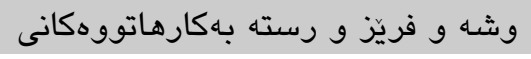

\begin{tabular}{|c|c|c|}
\hline رستهكان & فريّزهان & وشهكان \\
\hline عهمرت نهمينيى & ملى شكاو & ترحيّو \\
\hline رووت رهشبيّ & سلهى سير & وهحشى \\
\hline كو بخو & قونى ״ياز & 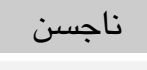 \\
\hline درو ئهكات & نيوهزهلام & 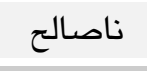 \\
\hline جارت دهويَ & ماكهرهسوره & جهـنهبازى \\
\hline بهخيّر نهيهيتهوه & مريشكى سهكباب & بهشهرهفم \\
\hline
\end{tabular}




\begin{tabular}{|c|c|c|}
\hline جيت بِييه بهرييهوه & كهنارى زَهنكدار & 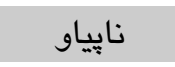 \\
\hline 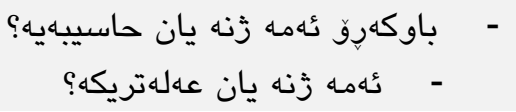 & زهلامى بيّعاهقل & 15 \\
\hline رووى بابت رهشبي & & كاجووت \\
\hline ئادهى تق بوّى ليدّرهوه & & هيج و يووت \\
\hline نازانم ئهمه فليم دهكات يا تارات & & قوزهلّورت \\
\hline ليّم مهيرسه؛ وهحشى & & كهر \\
\hline دروّ تئكهيت & & 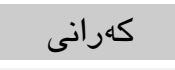 \\
\hline ئهم زهلامه بيّعاهره جِييه؟ & & 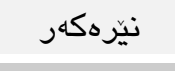 \\
\hline داوهشيت & & 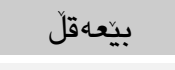 \\
\hline ملت بشكي & & \\
\hline كاسهار جوّى كرتييه & & تو شهرهف \\
\hline ملت بشكينه و برو & & \\
\hline باوكت له تهماتهى تهييو ئه هيّت & & بيئه خلاق \\
\hline سهرو فهسالت خواتهوه & & 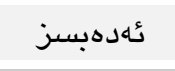 \\
\hline به شهارهفم توّش له بزن ئهجى & & حهيوان \\
\hline خوّت كهر مـككه & & قسـاهى قورِ \\
\hline من يشقل و ئهمه تهِالة & & زهرى مار \\
\hline \multirow[t]{8}{*}{ ئاخر خوّتان بيّعهقلّ و كهرن } & & كهرى ديزّ \\
\hline & & سوك \\
\hline & & 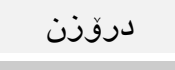 \\
\hline & & 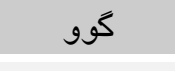 \\
\hline & & 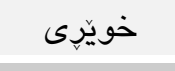 \\
\hline & & هـاهيم \\
\hline & & جهـتيو \\
\hline & & تركهن \\
\hline
\end{tabular}

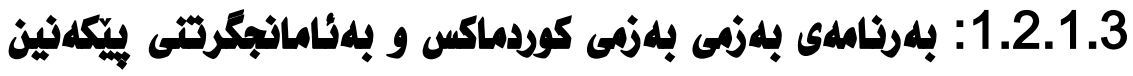

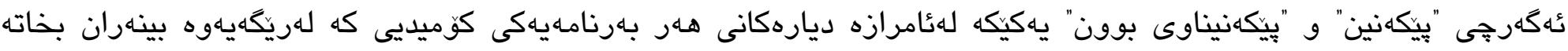

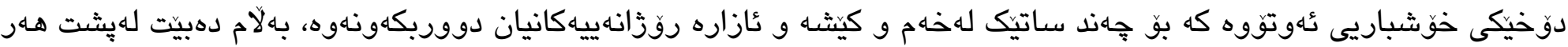

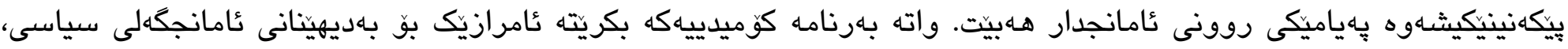

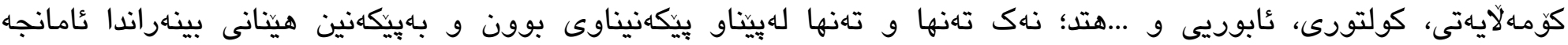

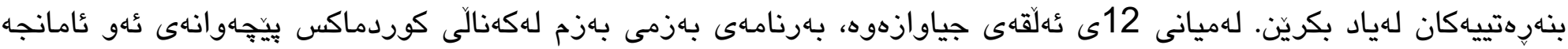

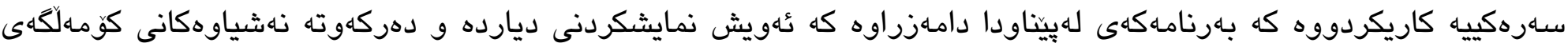




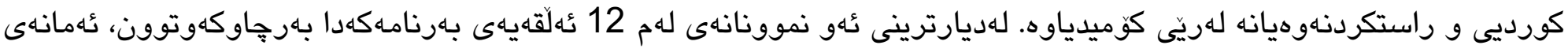
خواردوهن:

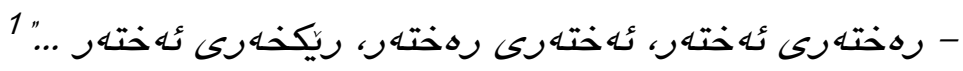

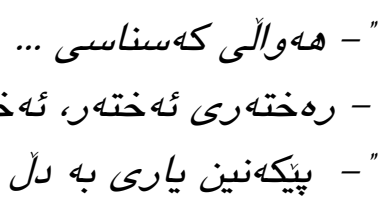

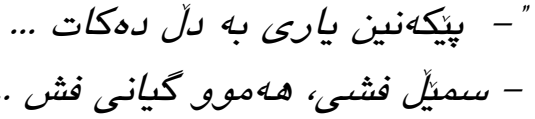

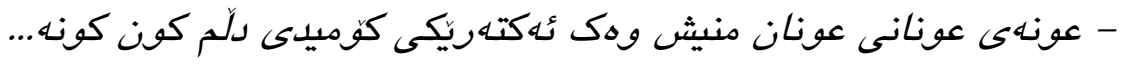

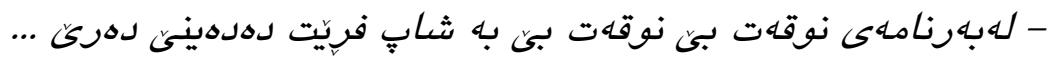

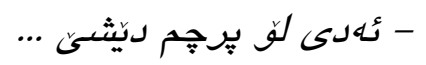

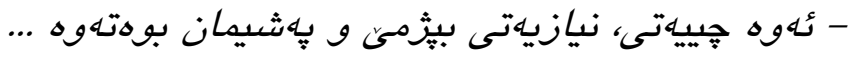

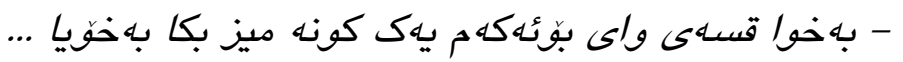

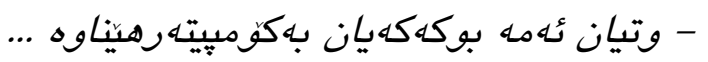

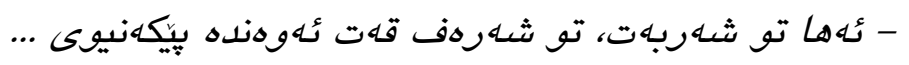

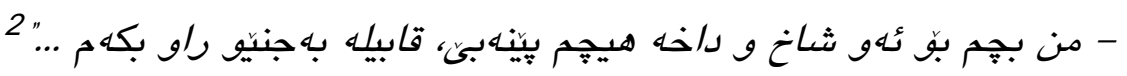
"-جنيو فرييه، جنيوى بيّيله، بهس ليَى قبول مهكه ..." 3

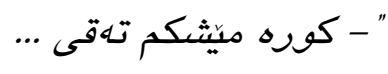

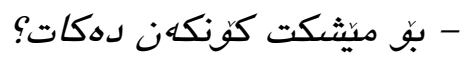

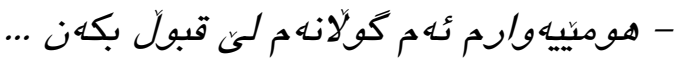

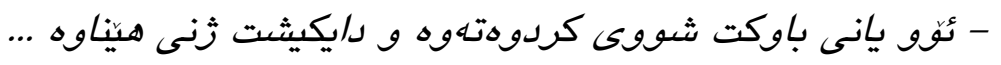

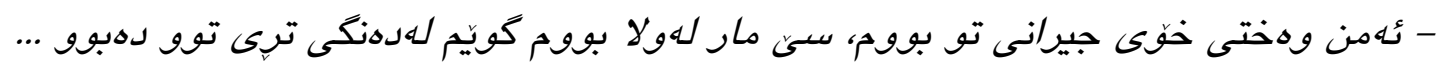

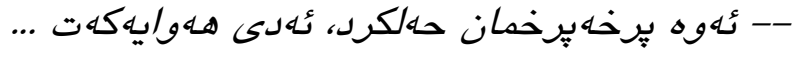

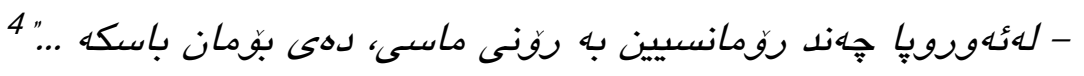

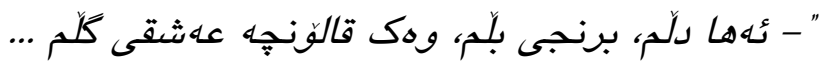

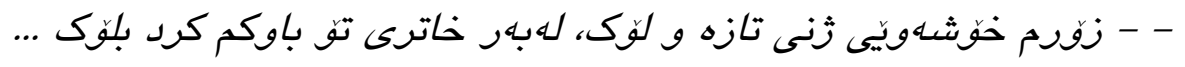

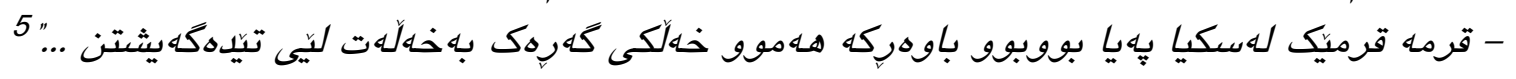

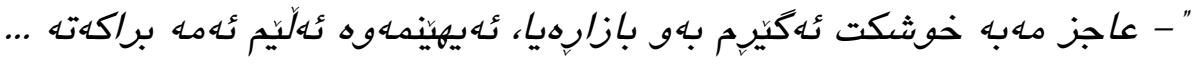

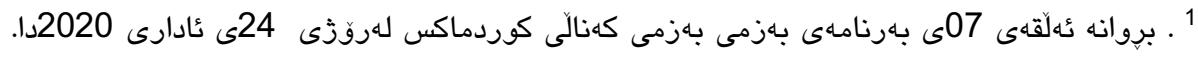

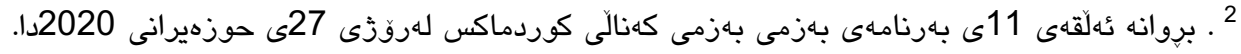

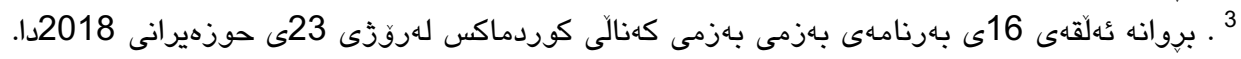

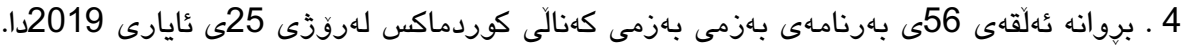

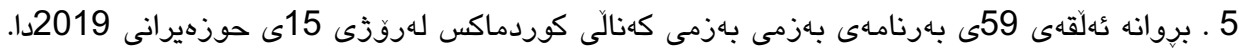


- بهورعان برغوى 13يى لينابيَ ئهيخوم ل...

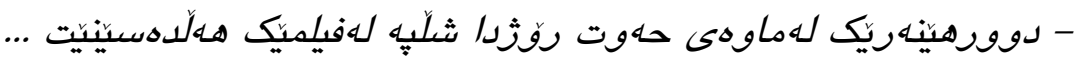

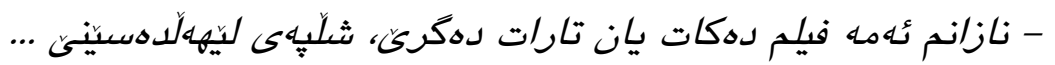

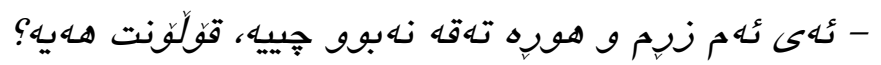

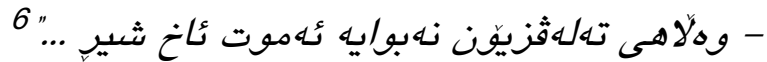

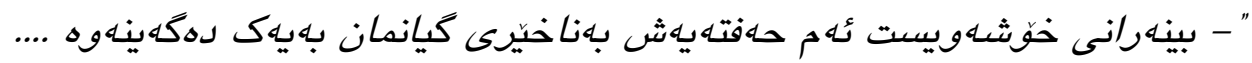

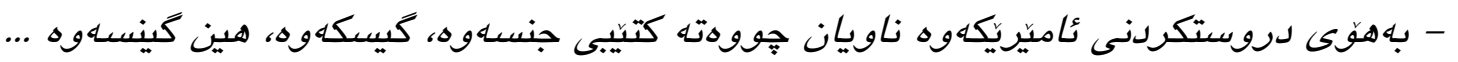

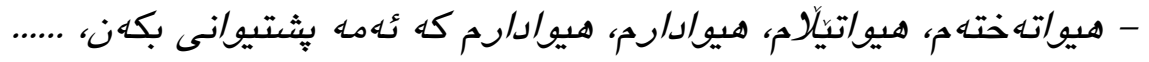

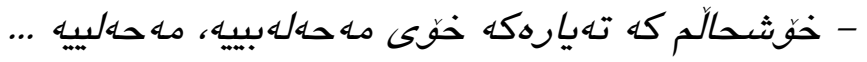

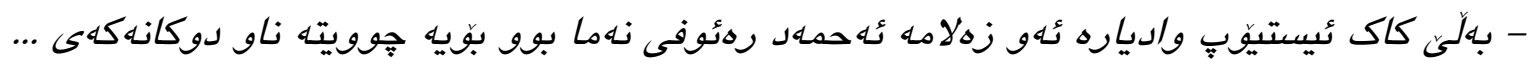

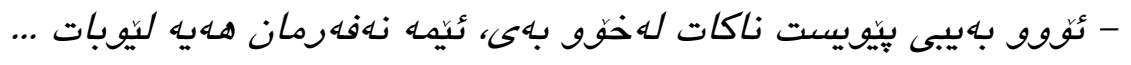

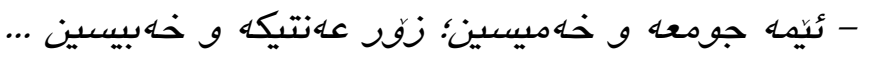

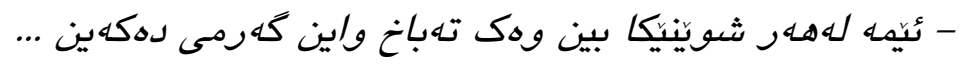

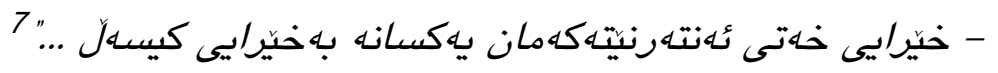

\subsubsection{3: بلهرنامهى بلهزمى بلهزم و برمودان به زمانى بازإيى و جنيّودان}

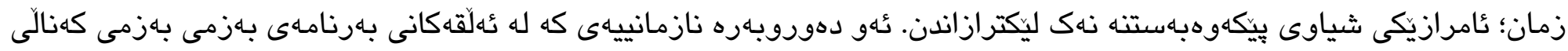

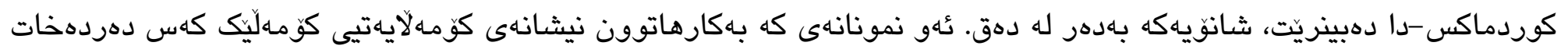

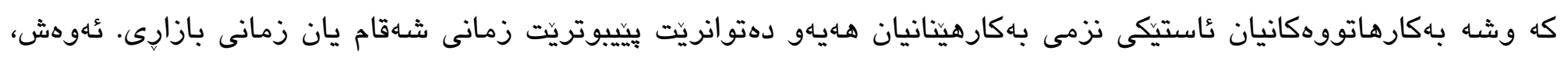

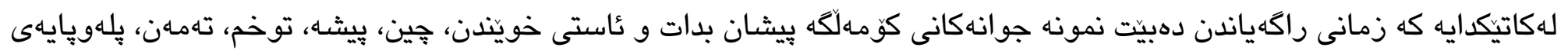

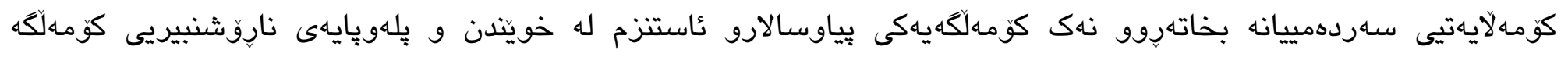

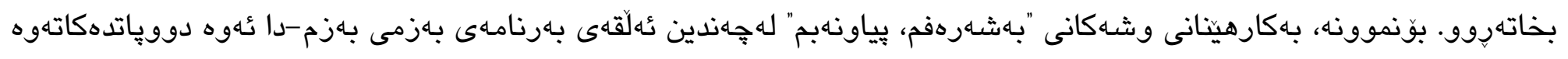

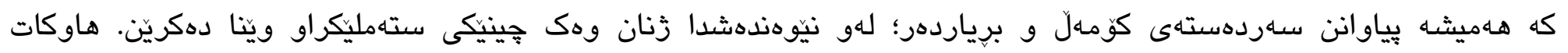

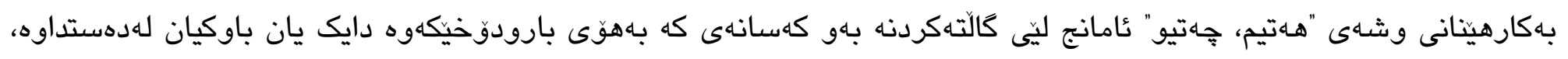

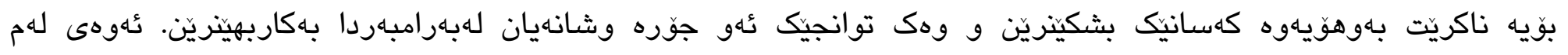

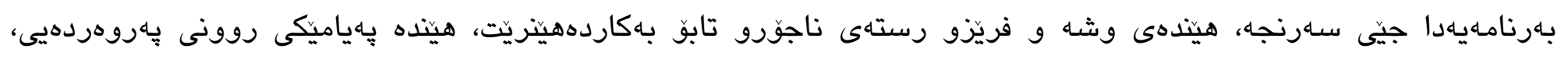

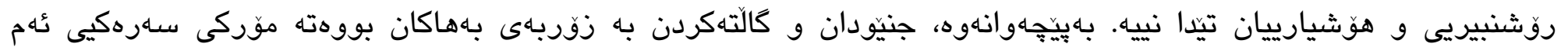

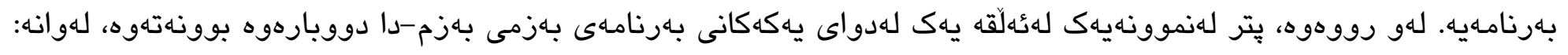

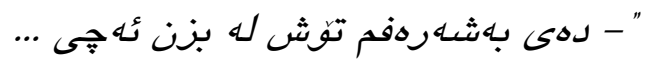

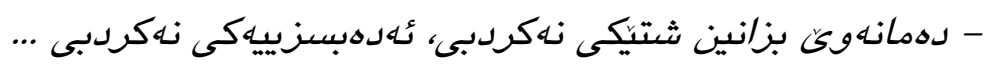

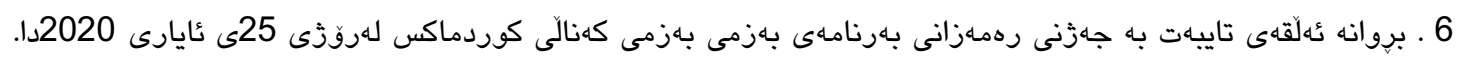

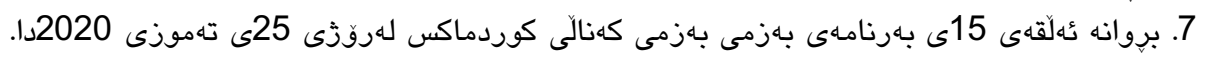


- ئهوه ما كهوه؟ له بهشهرهفم ما كهريش نييه ..

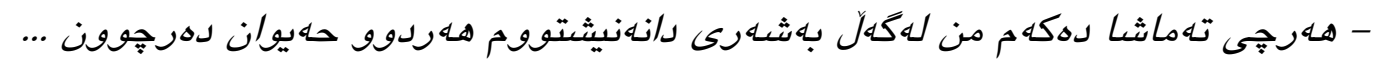

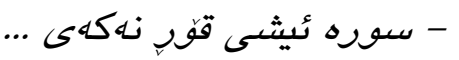

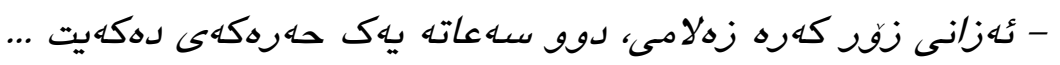

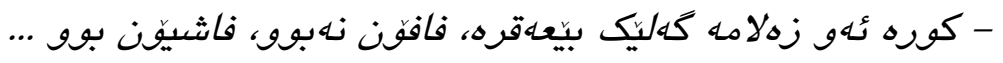

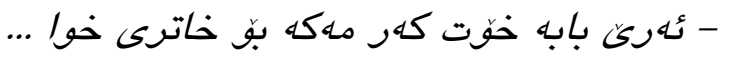

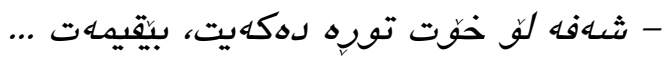

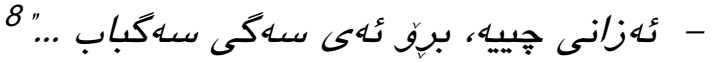

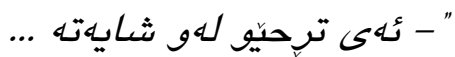

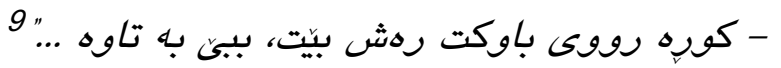

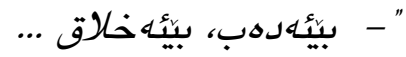

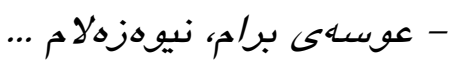

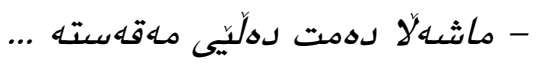
- ثٔهو ئهدهبسزه، لدهيويست سوار سهايارهت بكات و بتباته جنييهكى ديكه ...

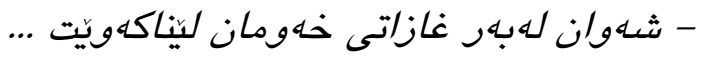

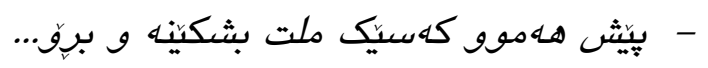

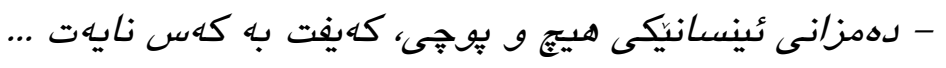

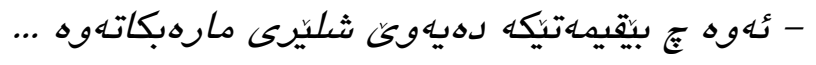

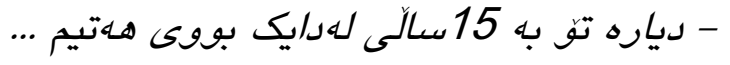
- 10 ....

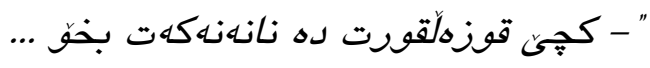

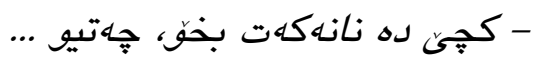

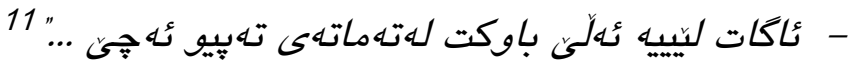
" - كوره لده دانيشه ئلَّيى مشكى نانهواخانهى...

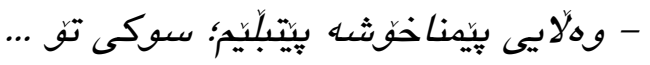

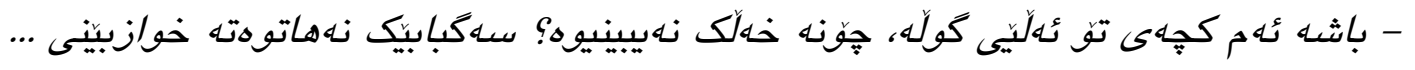

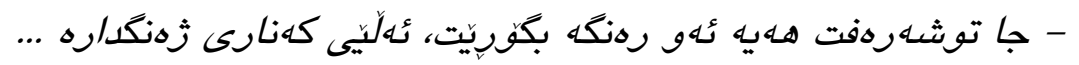

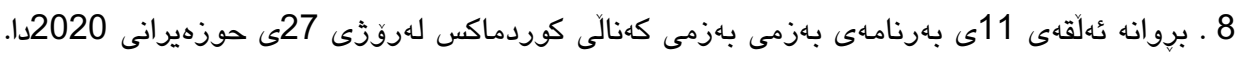

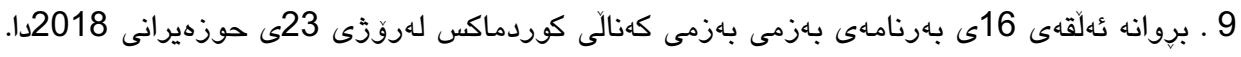

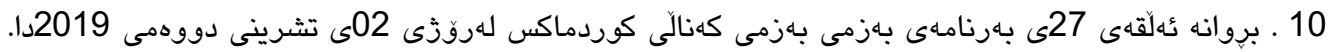

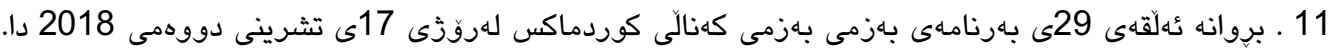


- كوره وه حشى ئهوه خيز//نمه تق داواى كيى لدكهيت؟

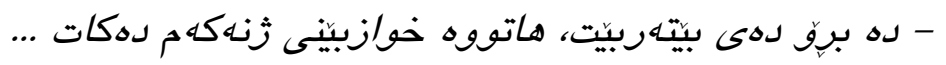

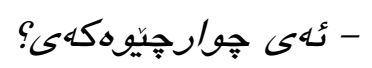

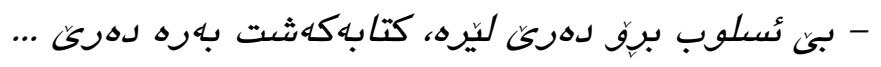

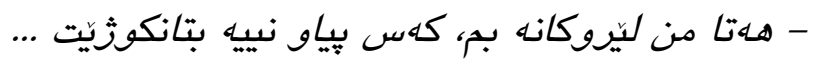

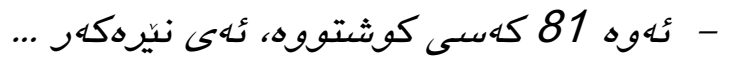

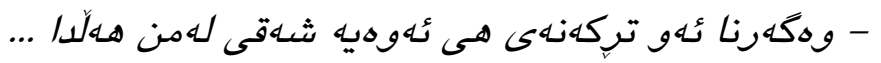
-كهس بوّى نييه كوى بخوا له من زياتر..." 12 " - قوربان غازات هـهيه غاز ...

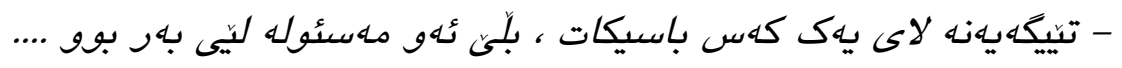

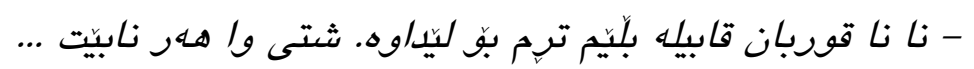

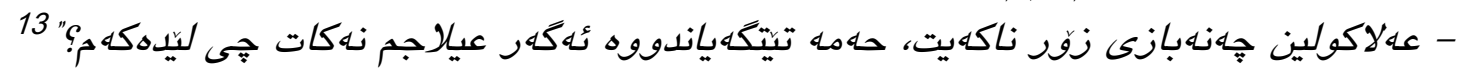

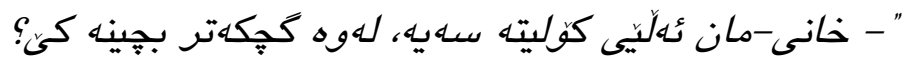

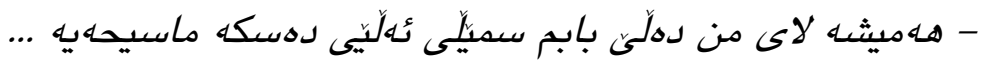

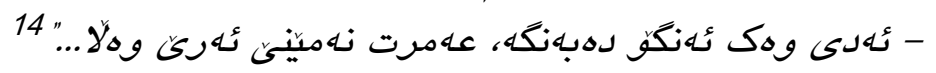

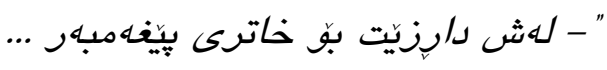

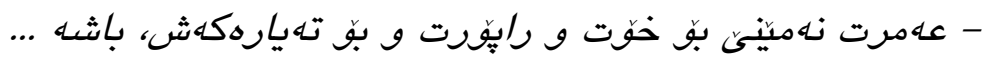

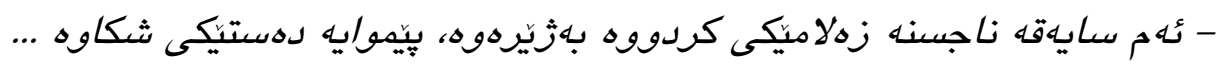

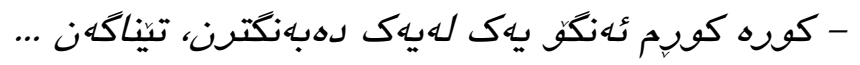

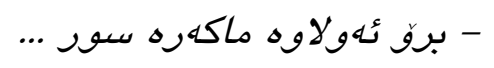

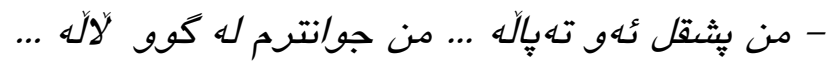

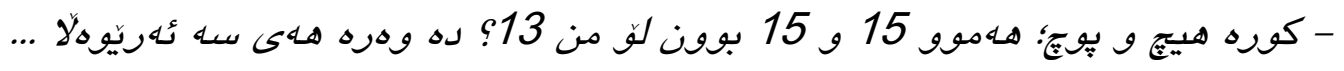

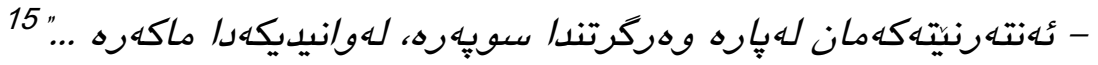

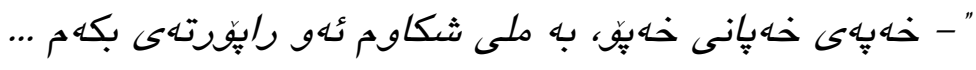

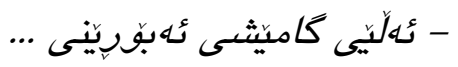

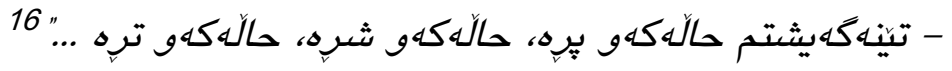

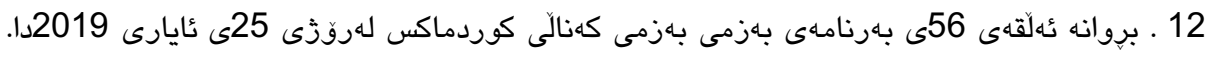

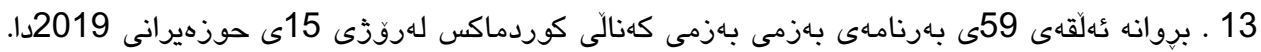

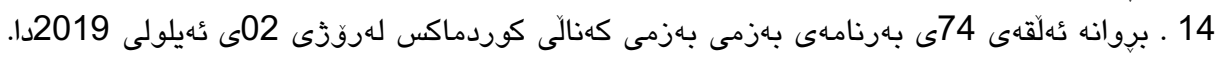

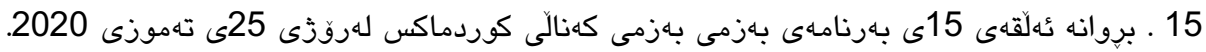

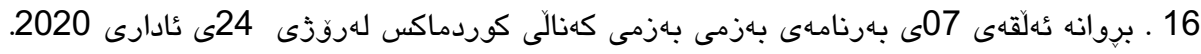


" - كولّناز ئهكهر تا ئهوديو بجِيت بزانم ناسالح جِيدهويت ...

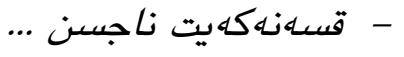

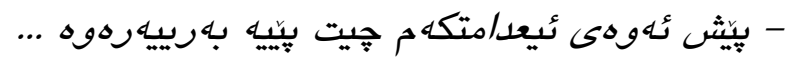

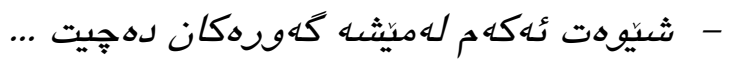

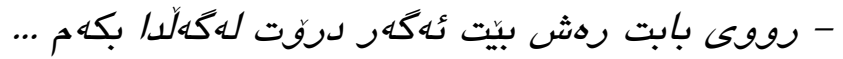
- عهلى؛ جهنه بازى مهكه ....

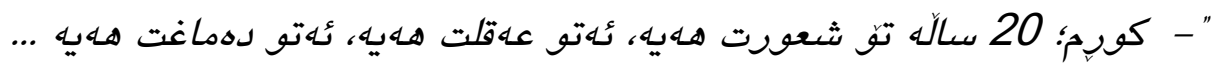

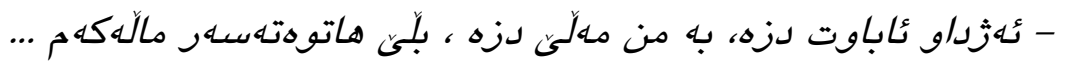

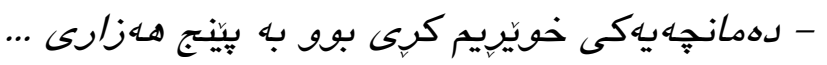

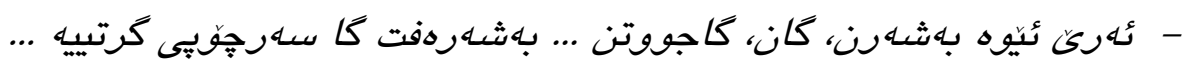

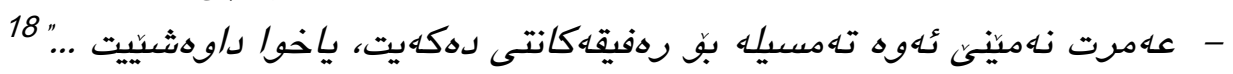
" - نانا عاقلانى كهرانى 10 زقورتره له 09 ...

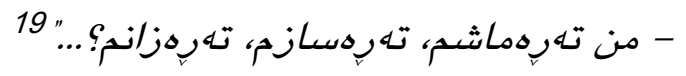

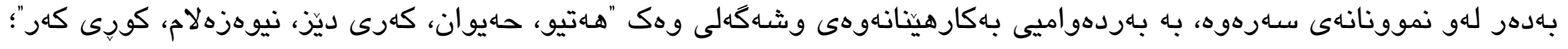

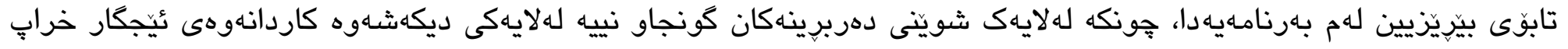

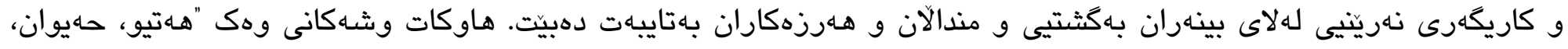

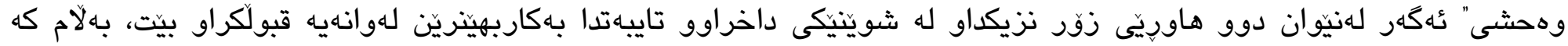

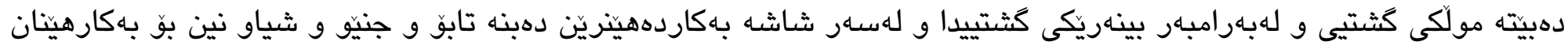

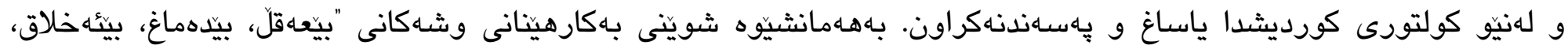

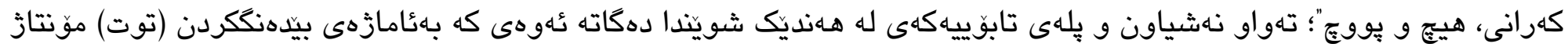

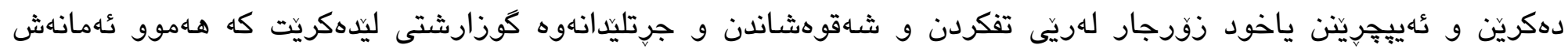

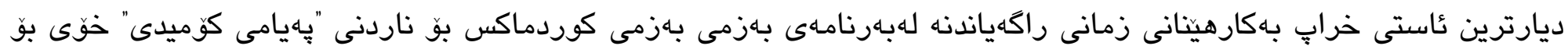
وهركردكانى.

3.2.1.3: بلررنامهى بلهزمى بلزم و برهودان به بيباوسالاويى و جياكاريى جيّندهرى

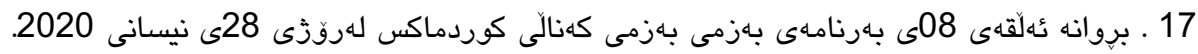

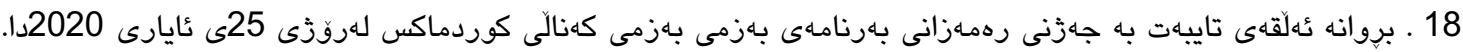

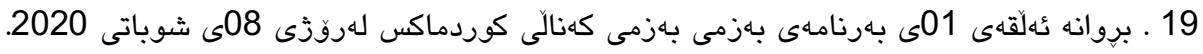




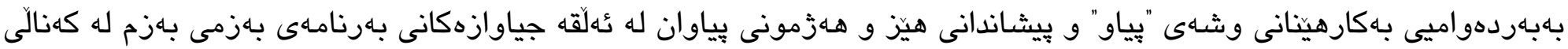

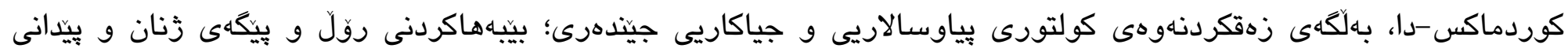

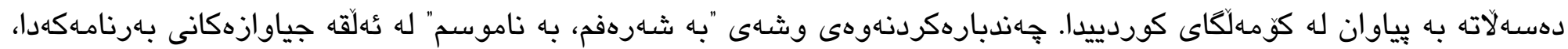

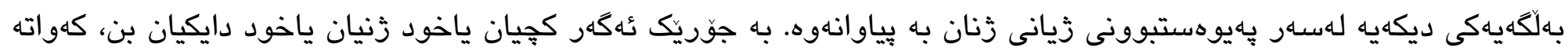

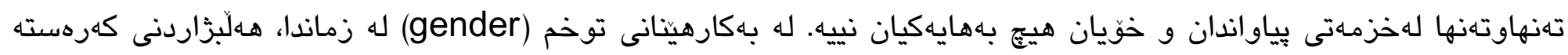

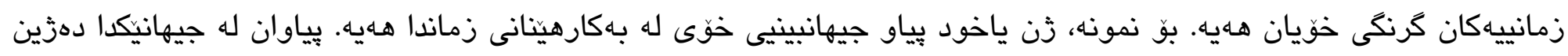

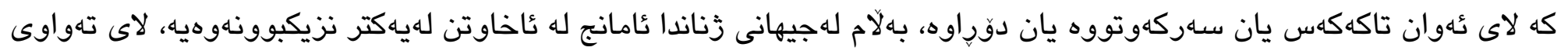

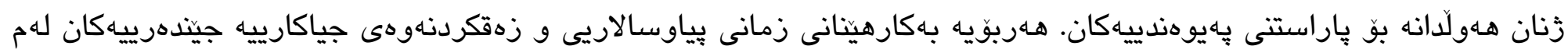

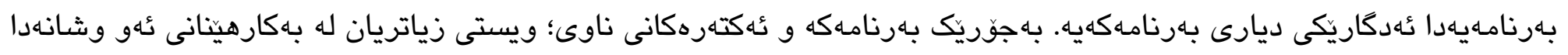

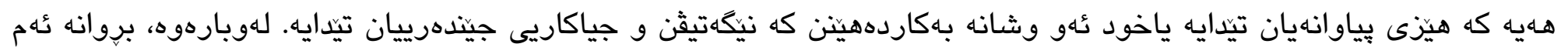

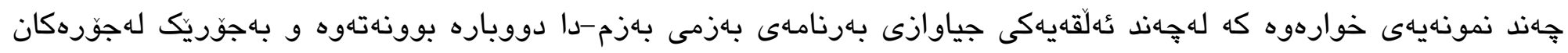

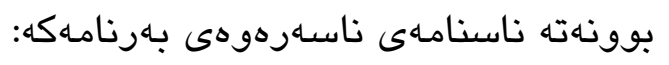

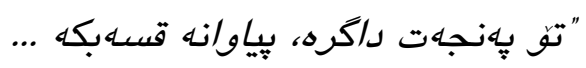

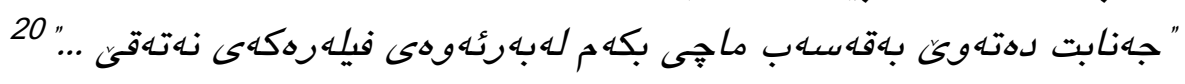

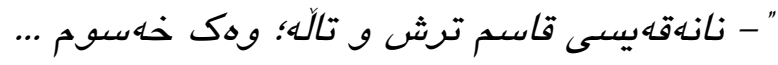

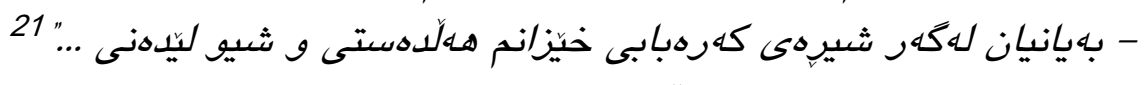

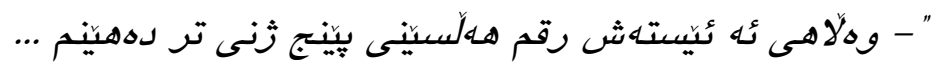

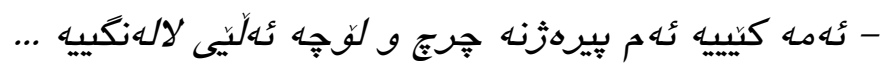

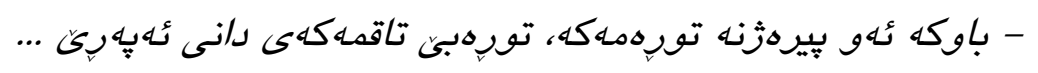

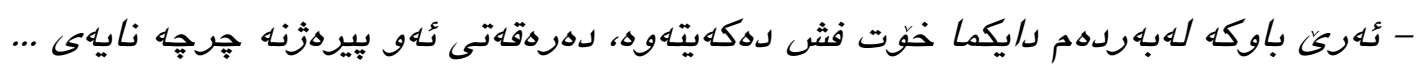

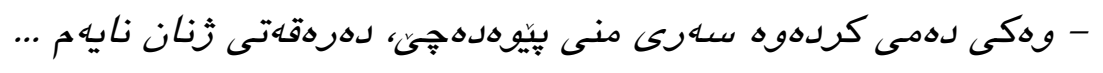

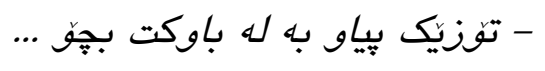

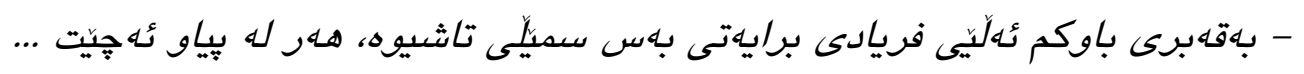

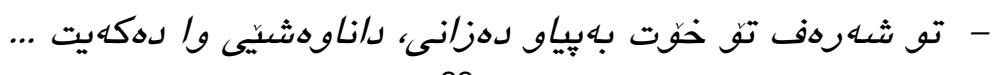
- تو شهردف ئهوه نعلى بياوه ..."

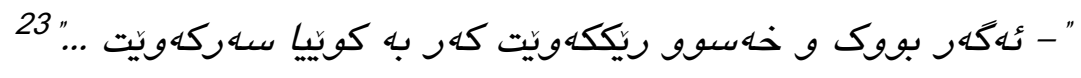

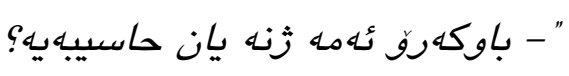

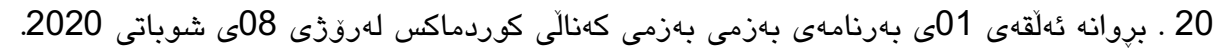

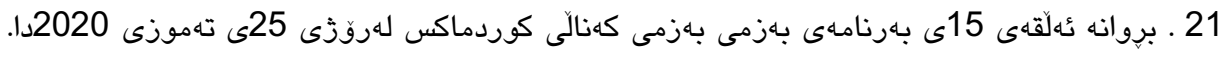

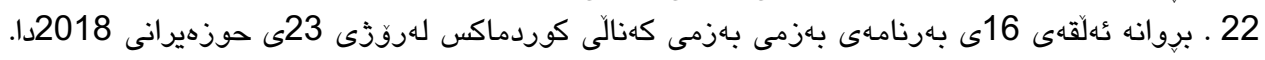

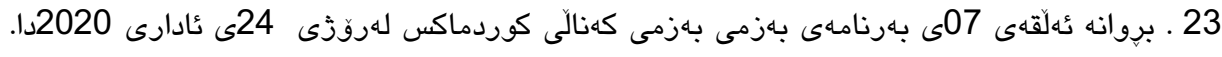


_ئهى تقو دهم و جاوت فيلهر نهكردبوو، ئهوكوت قهراغه كوليّرهيه؟

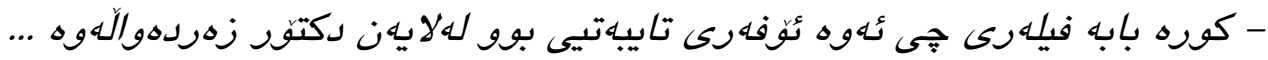

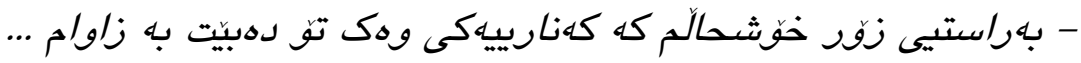

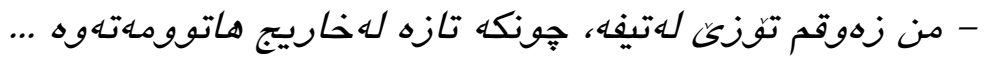

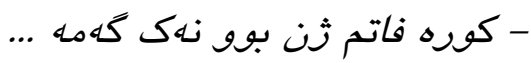

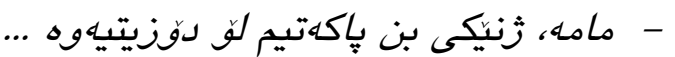

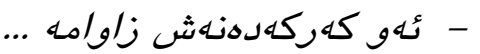

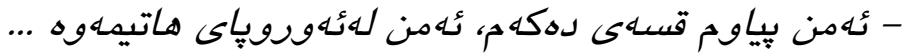

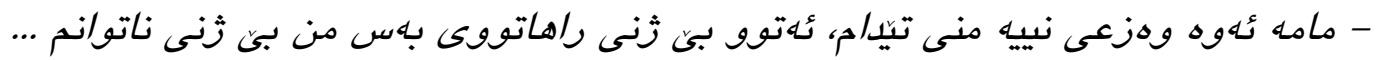

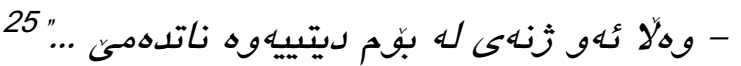

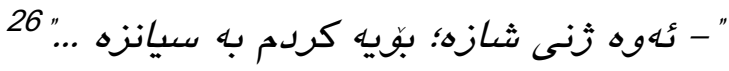

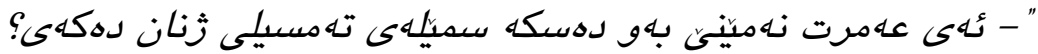

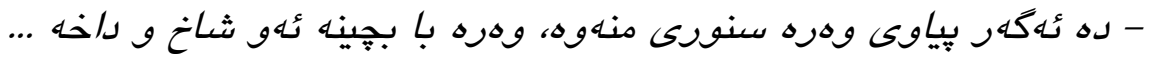

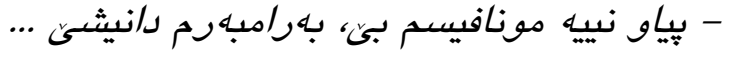

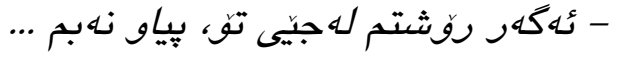

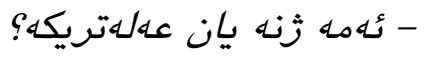

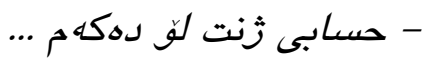

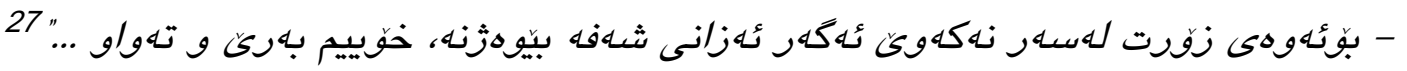

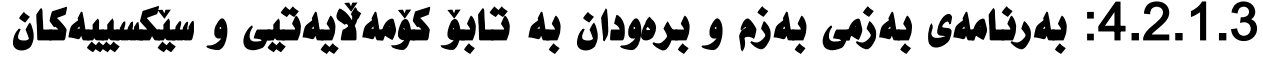

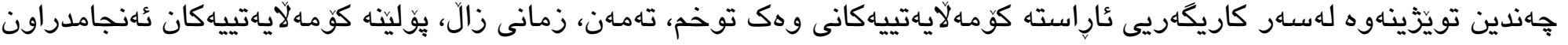

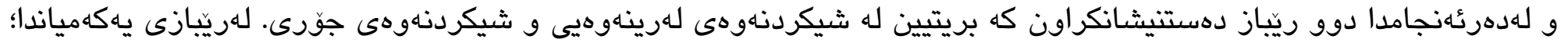

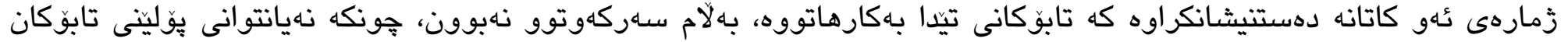

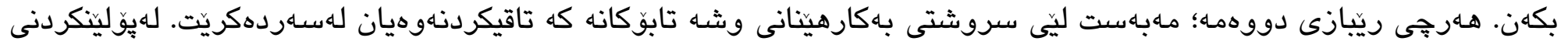

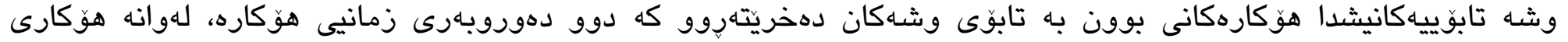

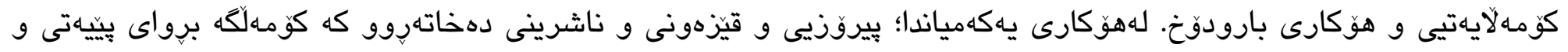

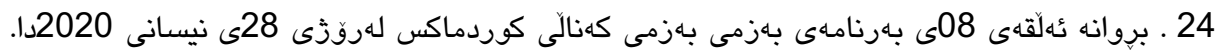

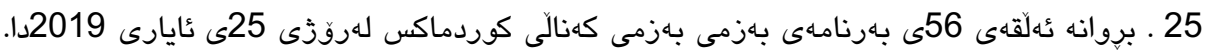

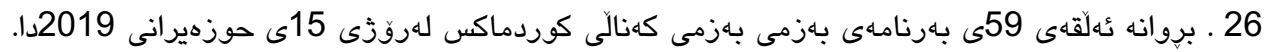

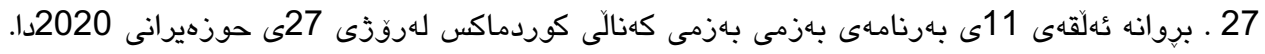




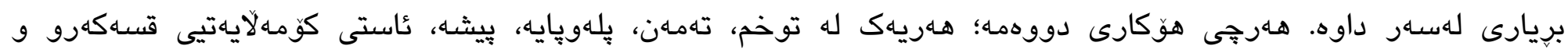

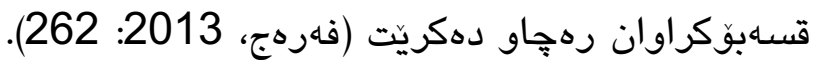

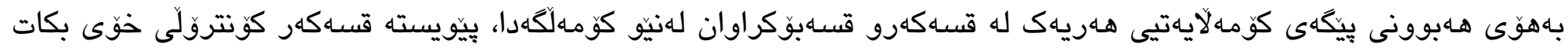

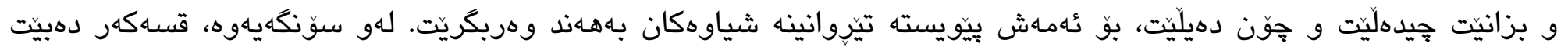

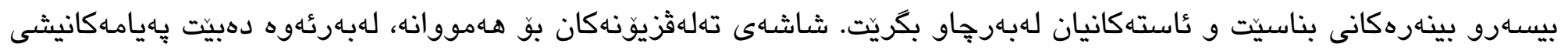

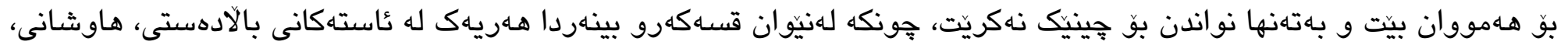

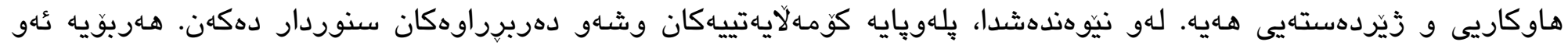

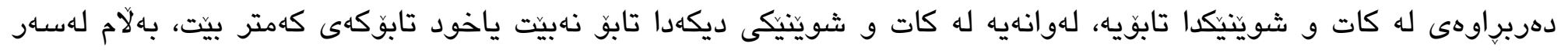

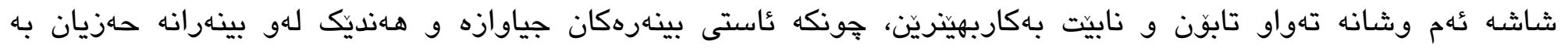

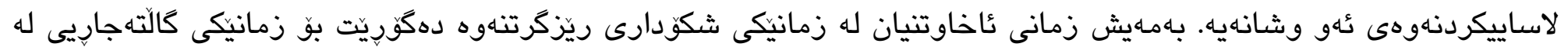

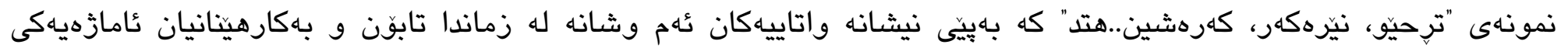

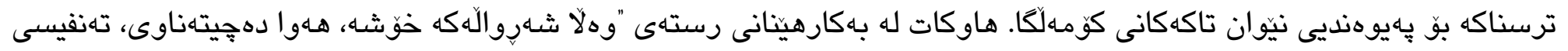

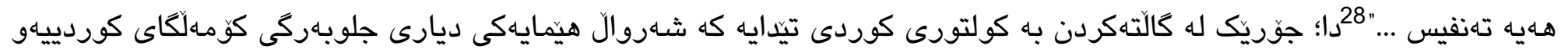

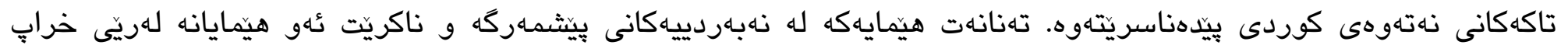

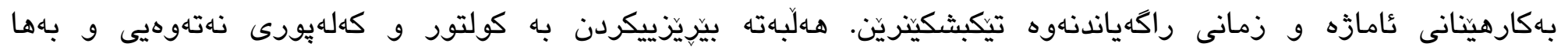

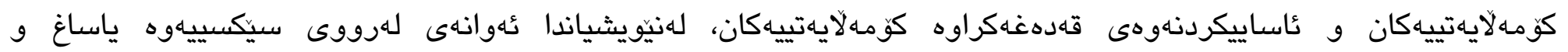

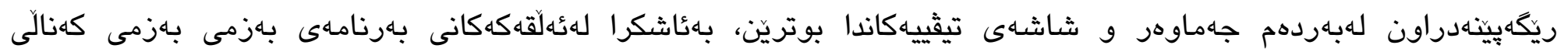

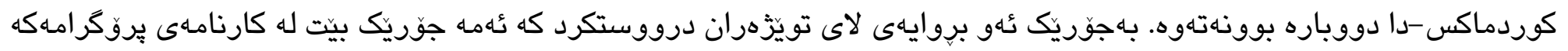

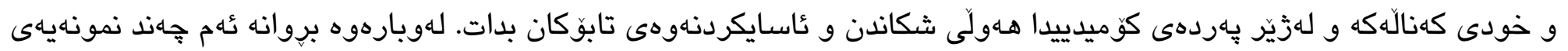

" - يانسى هـر شونينيكى حهساسم بخوريّيت، نهيخورينم ...

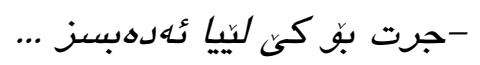

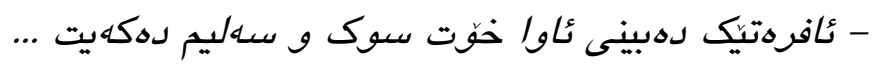

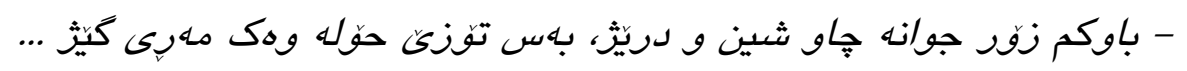

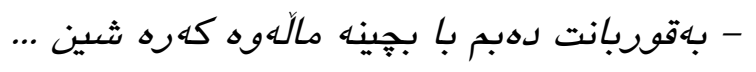

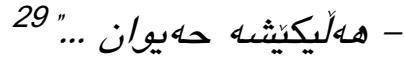

" - فه حسى عام جِييه، تق لكتورى كوردهوارى نى؟

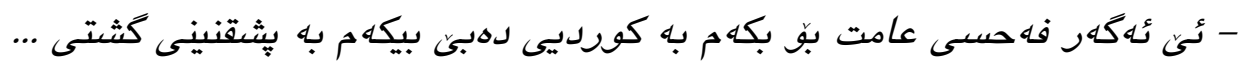

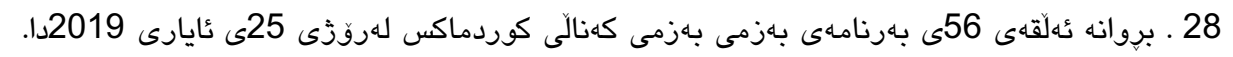

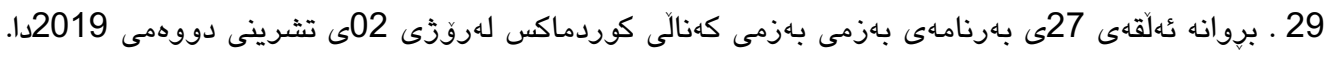




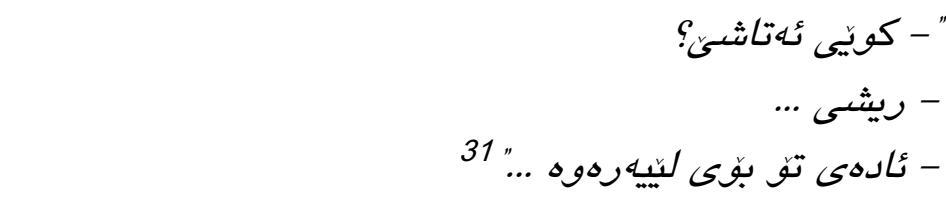

" - دهى فهرموف روقنى بكهرهوه بهس ئاوى تيمهكه بوّمان ...

- ده زوف زوق بوّمان دهرخه ..." 32

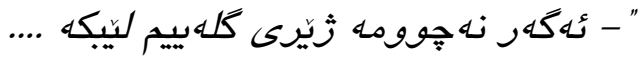
- بيكره يهلا باريكه ....

" - تق خوشك و دايكت هـهيه؟

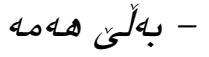

- هـرجى لق و لردختى براوه هـهيه به......

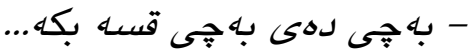

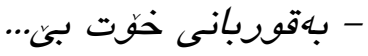

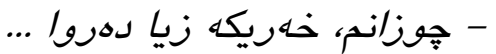

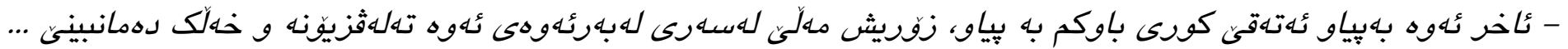

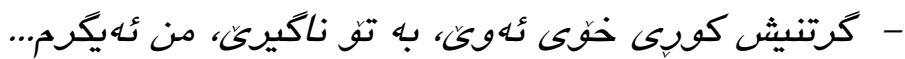

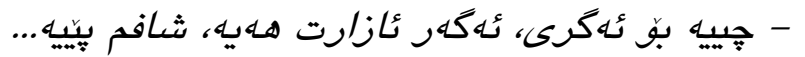

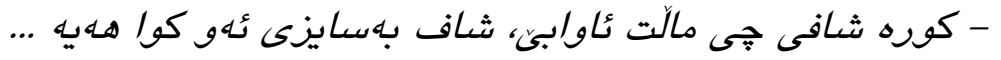

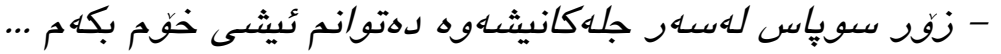

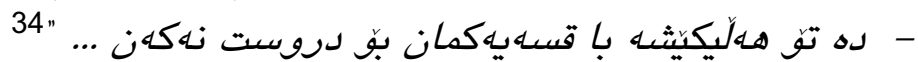




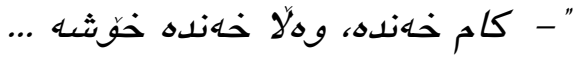

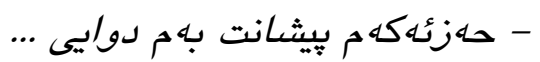
36 ,

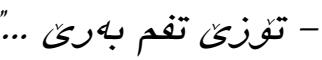

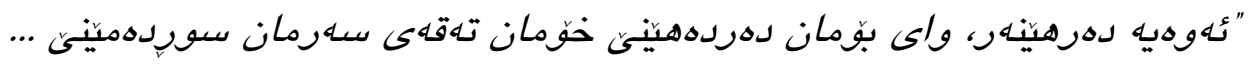

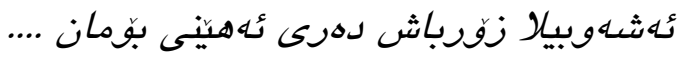

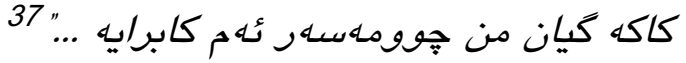

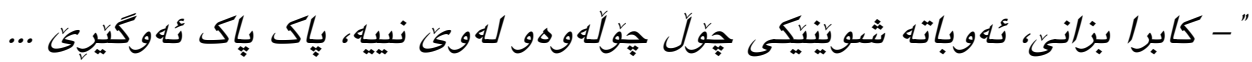

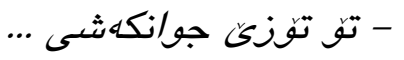

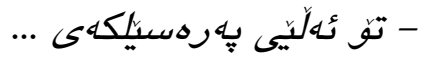

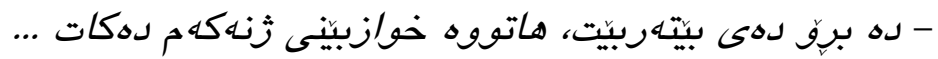

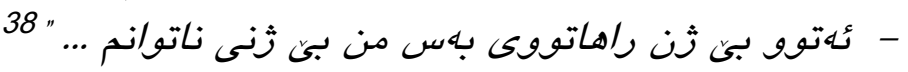

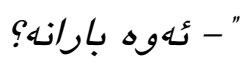

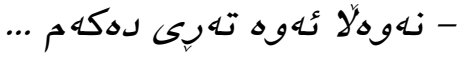

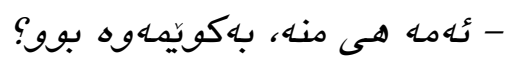

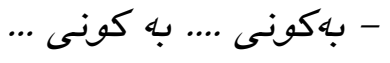

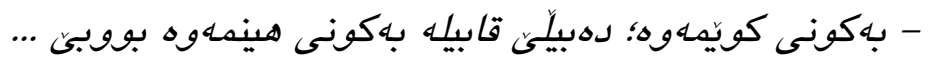

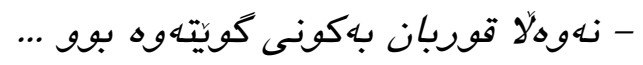

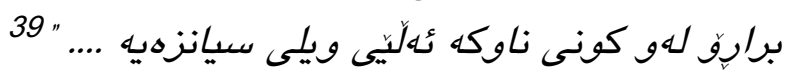

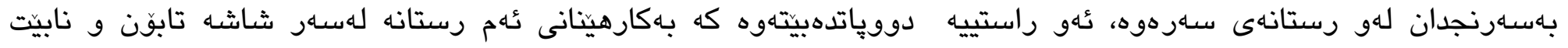

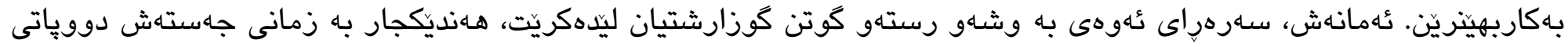

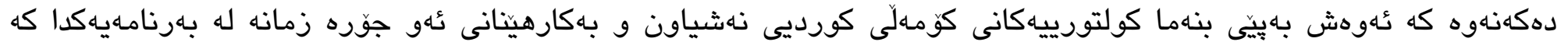

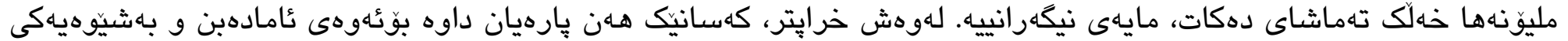

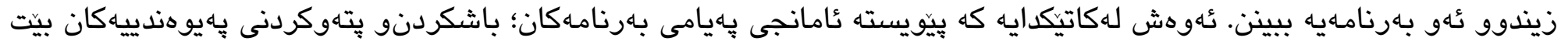

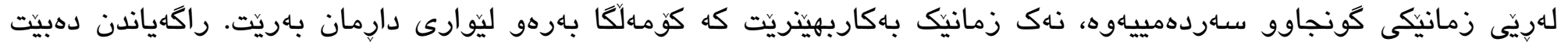

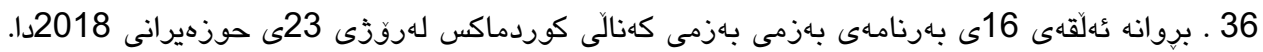

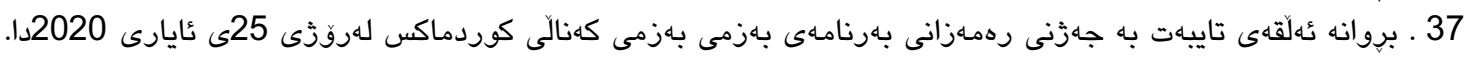

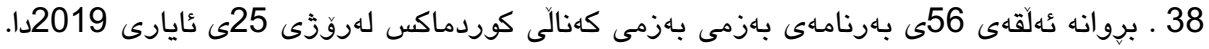

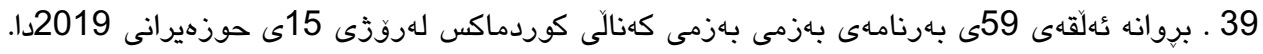




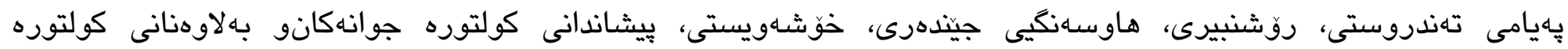

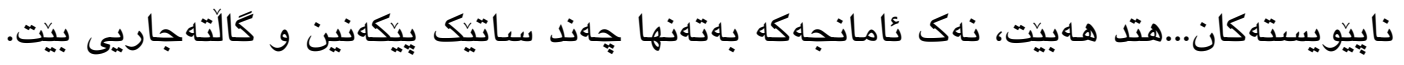

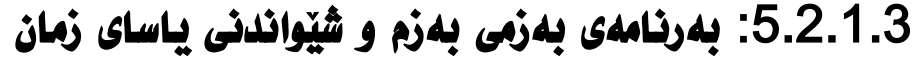

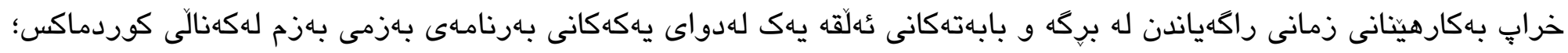

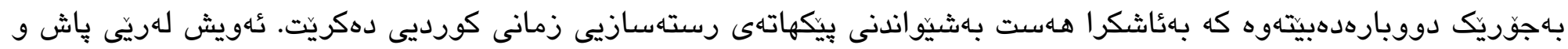

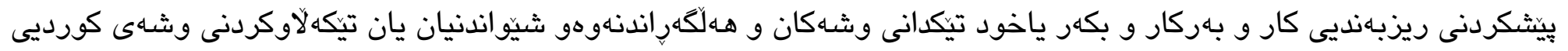

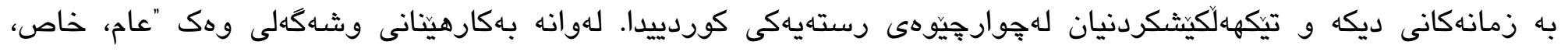

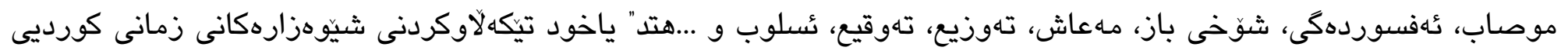

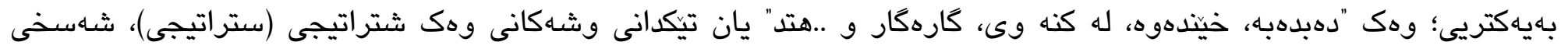

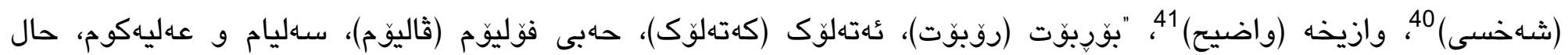

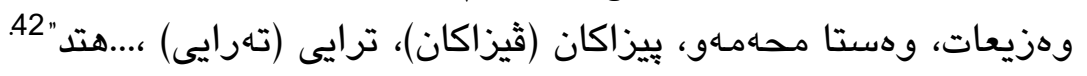

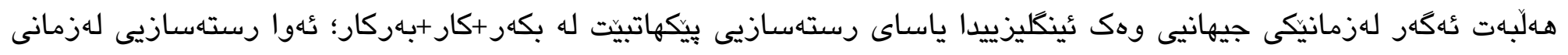

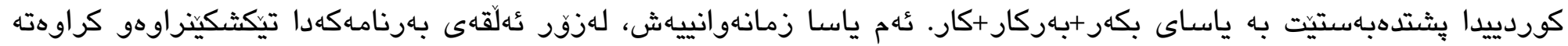

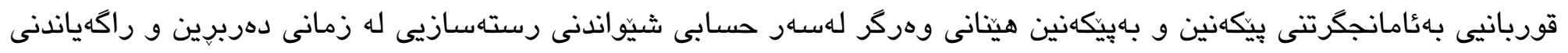

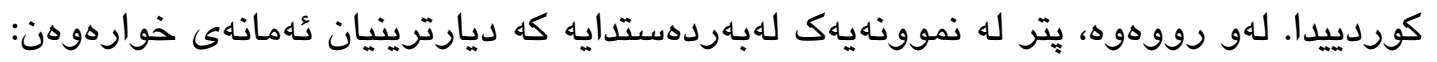

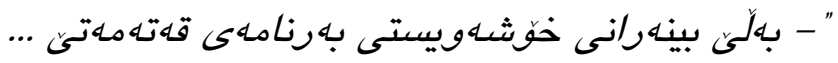

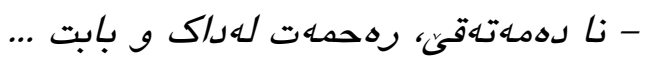

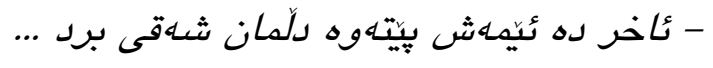

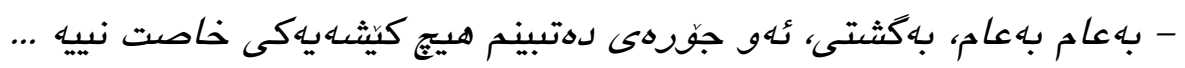

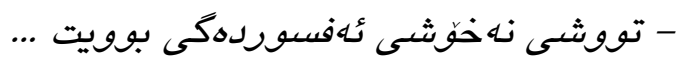

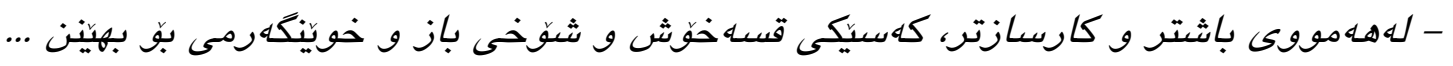

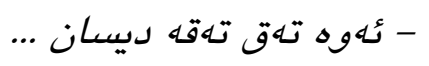

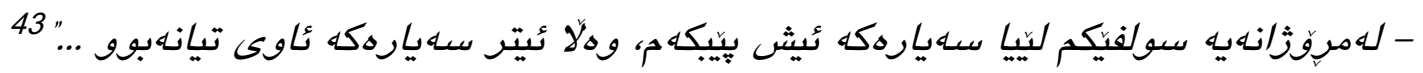

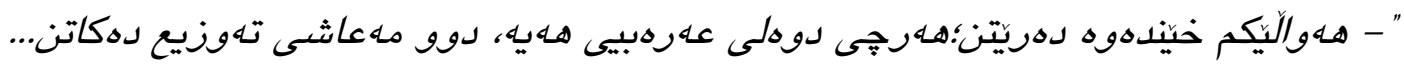

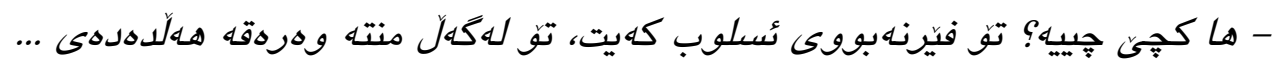

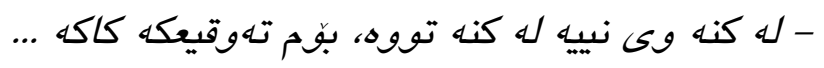

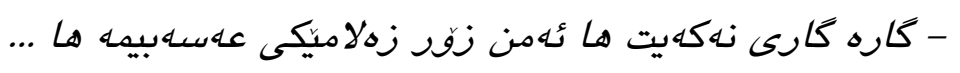

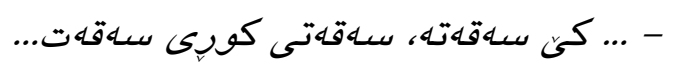

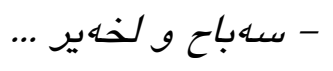

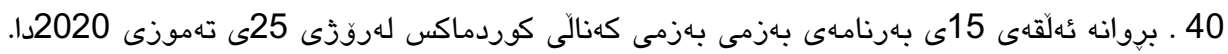

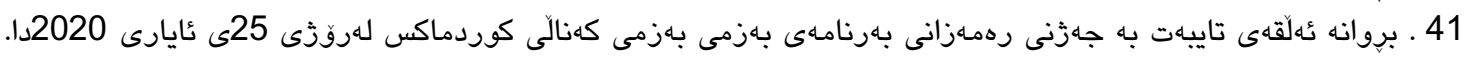

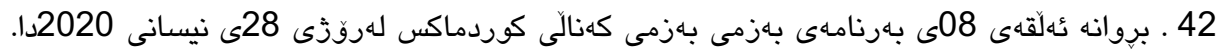

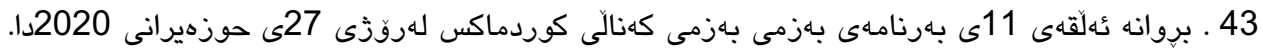




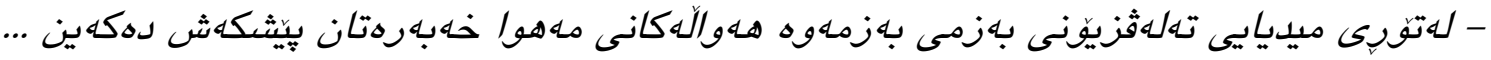

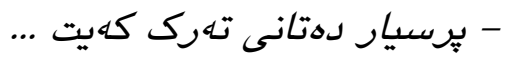

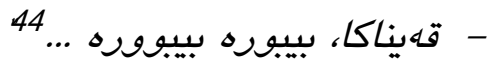

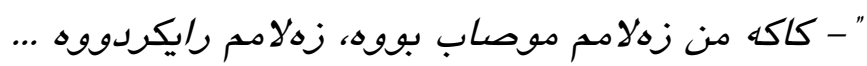

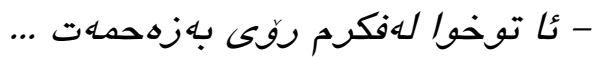

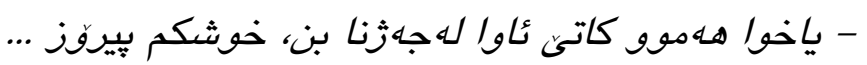

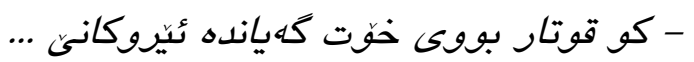

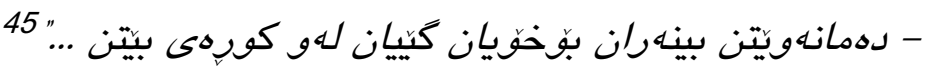

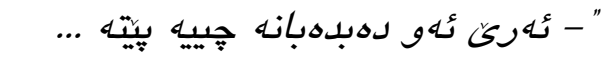

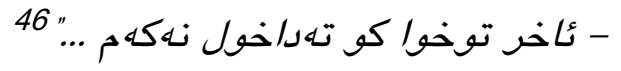

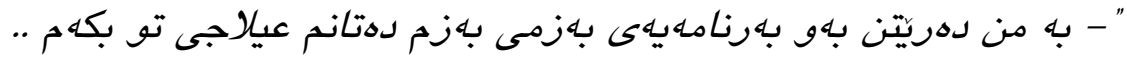

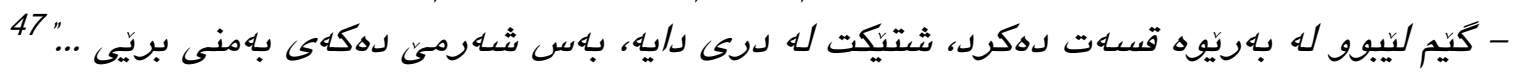

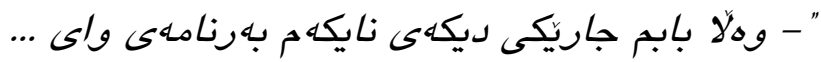

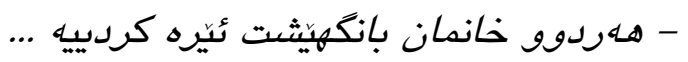

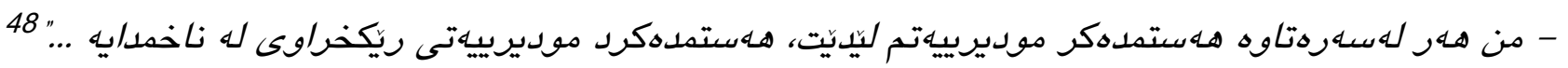

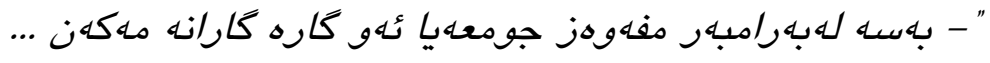

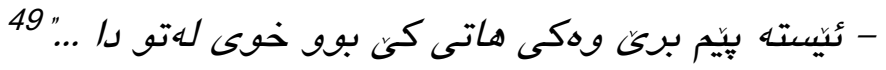
" - يّيوتى باوكه من ناتوانم ئهو زيندهكييه تهقهبولكه م، من تهلاق وهردهكرم ...

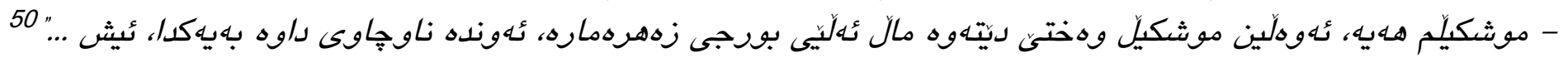

\subsubsection{3: بلهرناملى بلهزمى بلهزم و برمودان بله ناو و ناتؤره}

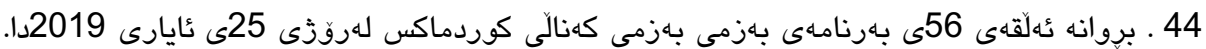

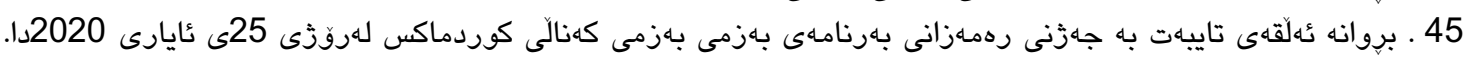

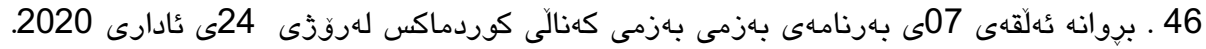

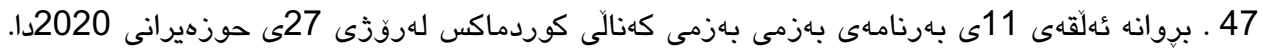

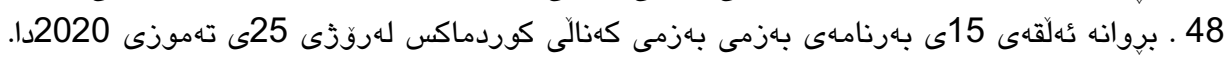

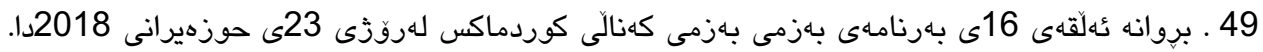

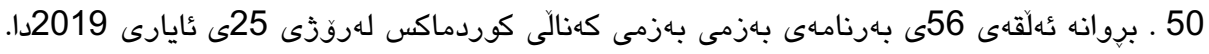




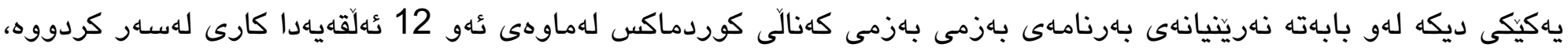

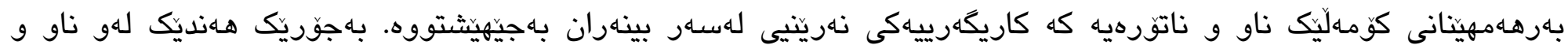

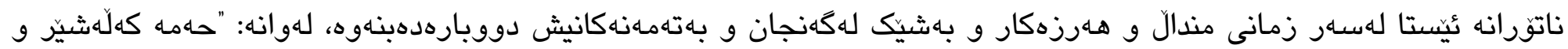

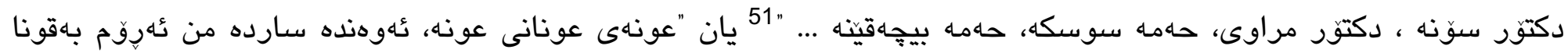

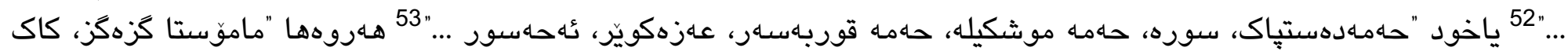

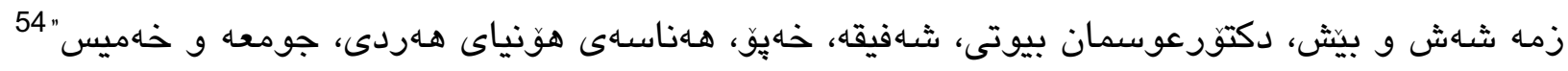

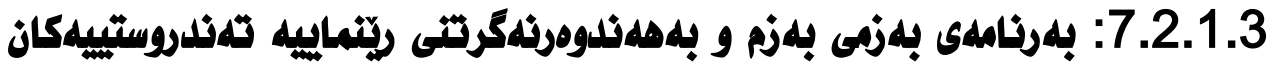

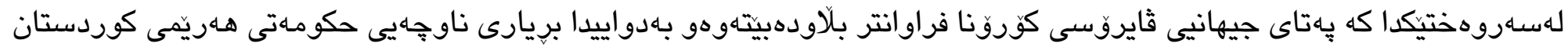

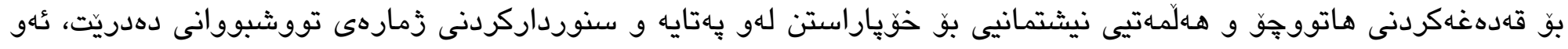

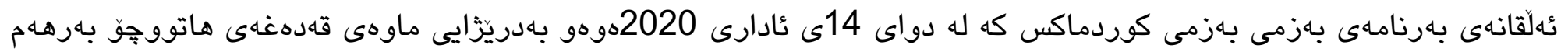

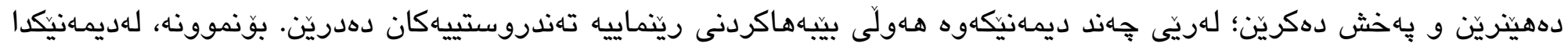

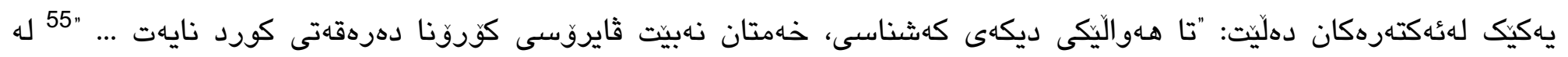

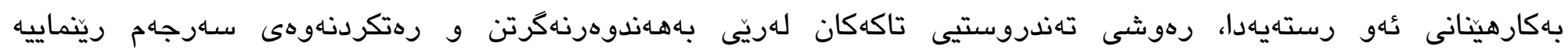

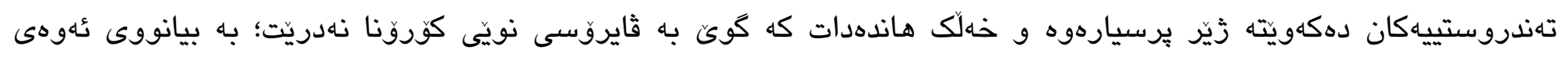

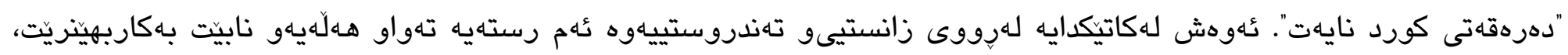

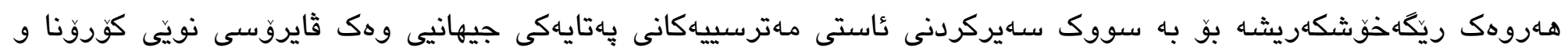

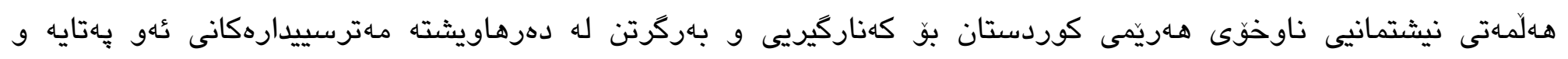
سنورداركردنى.

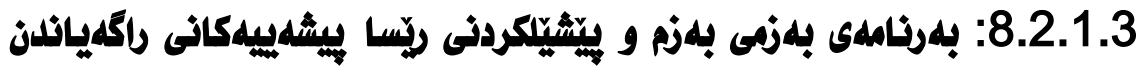

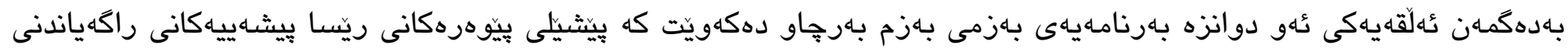

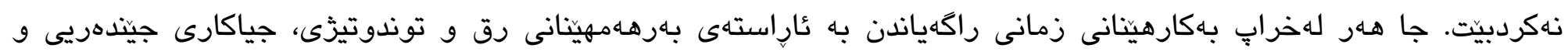

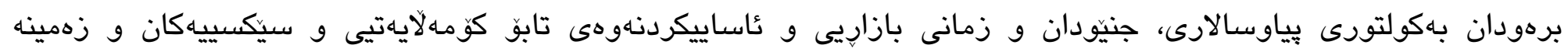

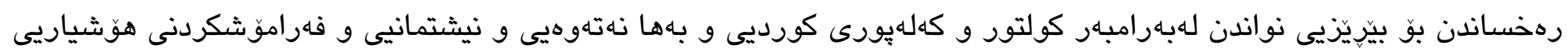

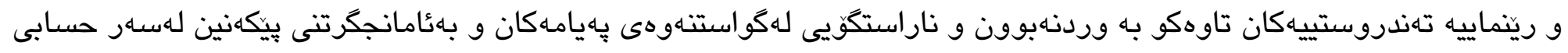

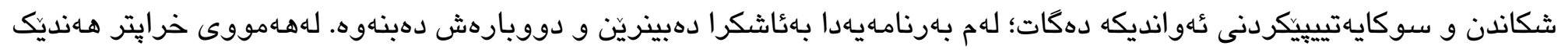

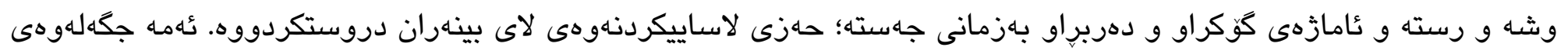

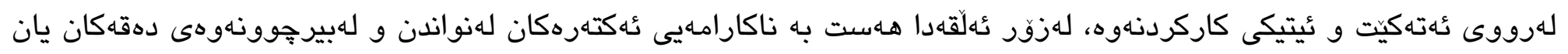

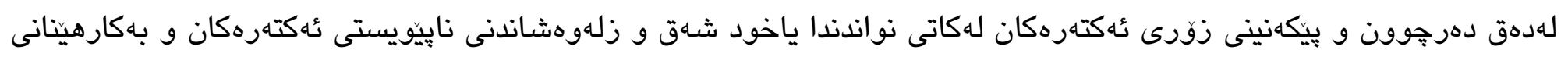

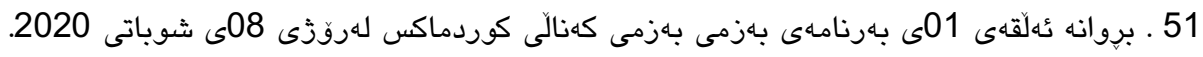

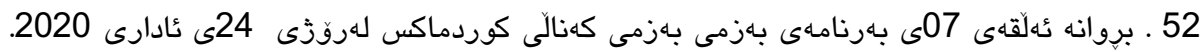

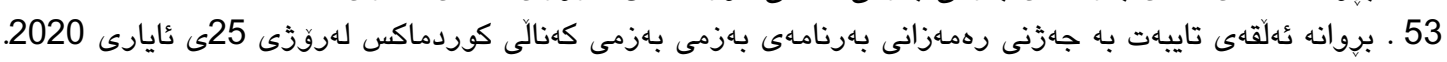

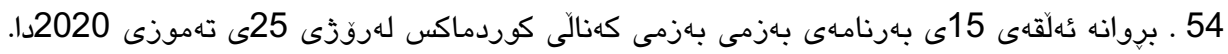

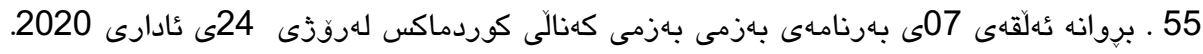




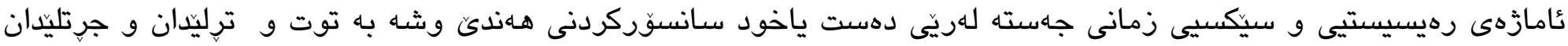

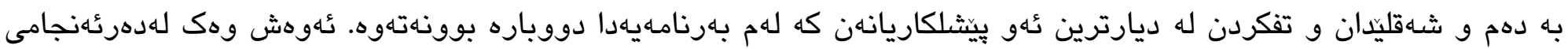

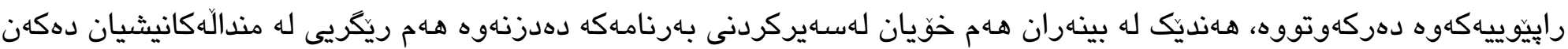
كه سهيرى بكهن.

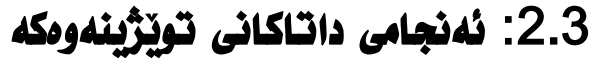

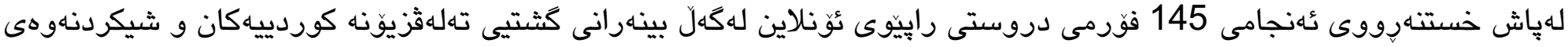

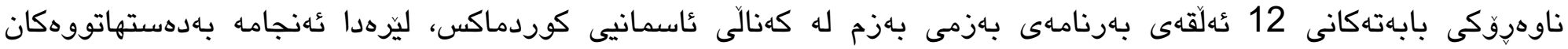

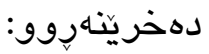

1. زانيارييه كهسييهكانى بينهرانى بهشداربوو لهراييّوى ئوناين بهجوّريكه كه لهرووى جيندهرييهوه، 60.7\% له رهكهزى نيّر

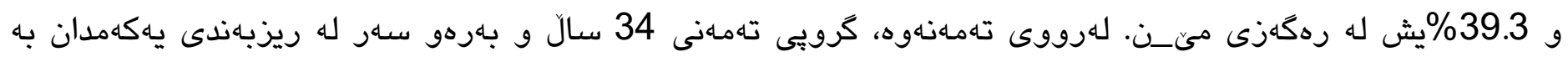

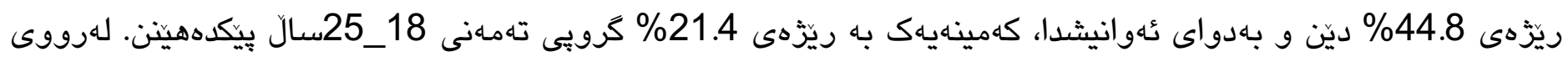

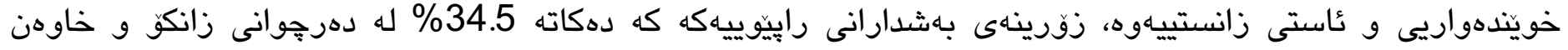

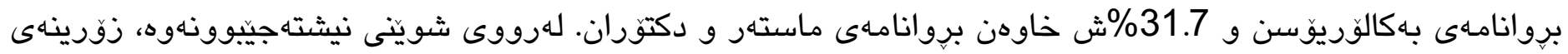

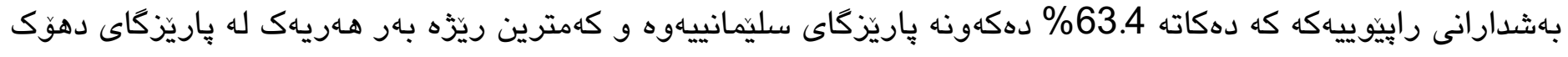

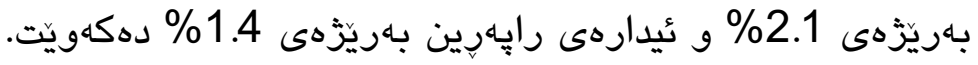

2. كوردماكس؛ وهك كهناليّكى خوشبارى (ترفيهى) كورديى لهلاى زورينهى بهشدارانى راييّوييهكهوه كه دهاته 64.1\%

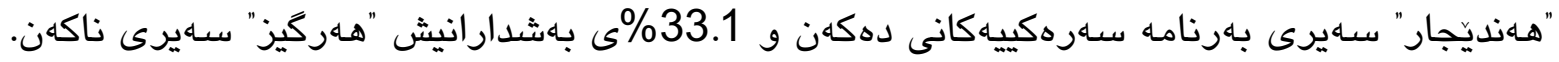

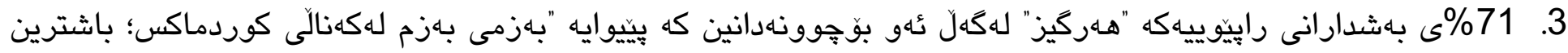

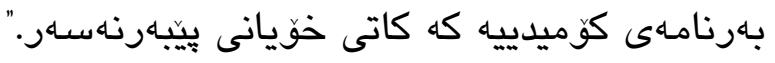

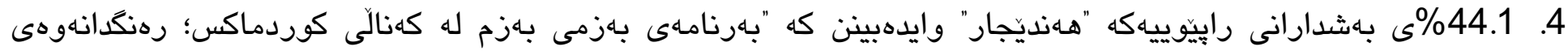

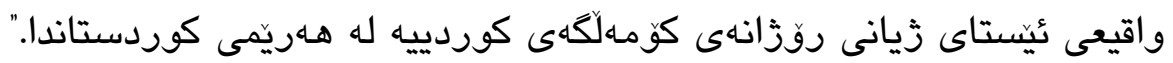

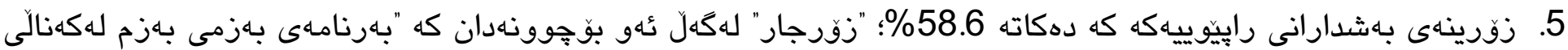

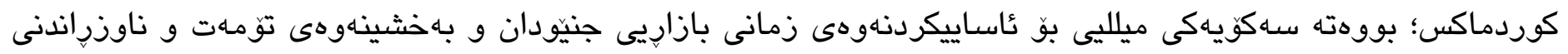

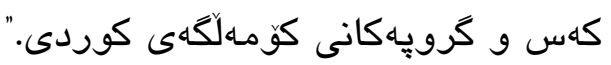

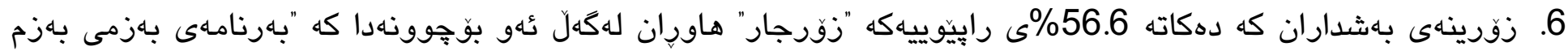

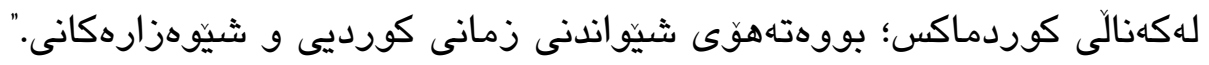




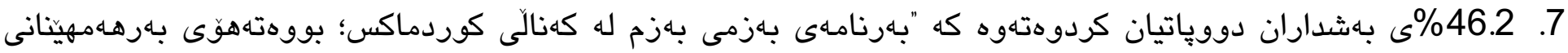
توندوتيزى زارهكيى و دهروونى".

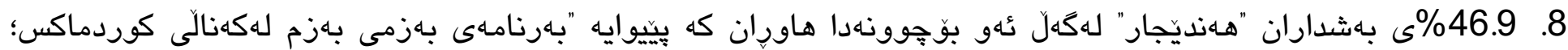

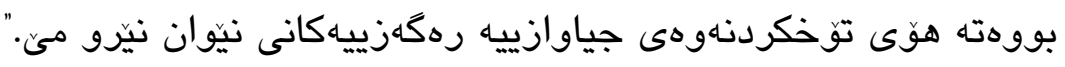

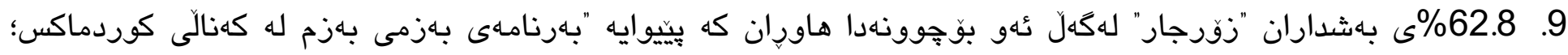

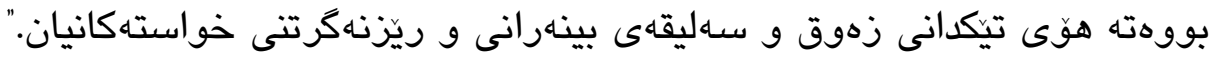

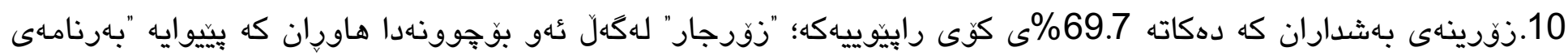

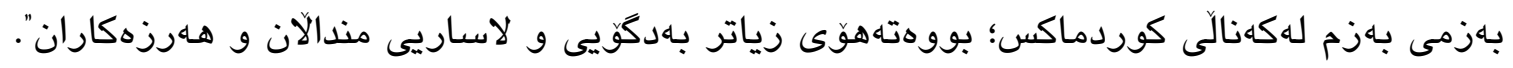

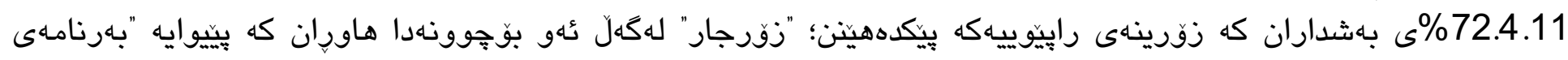

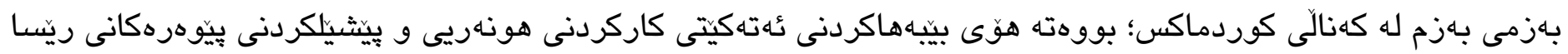

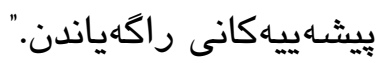

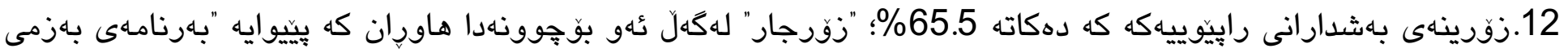

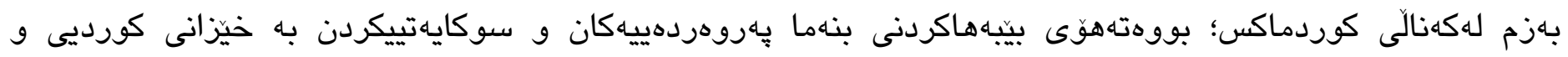
تايبهتمهندييهكانى."

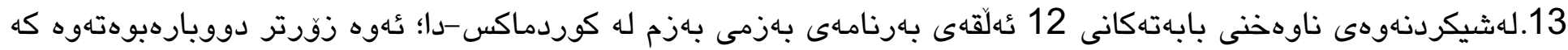

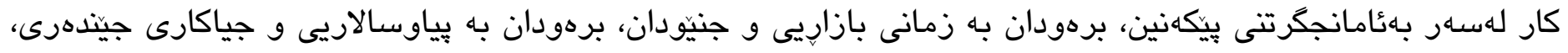

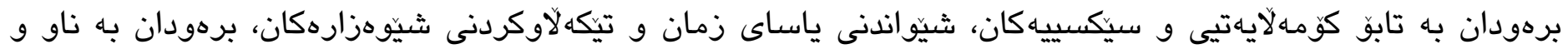

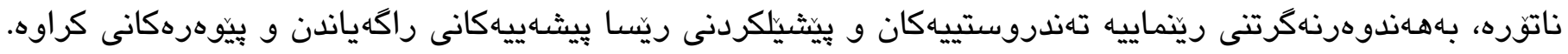

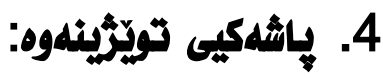

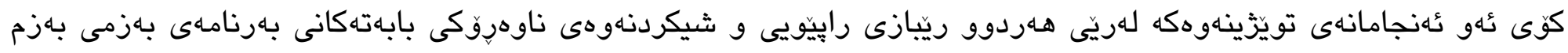

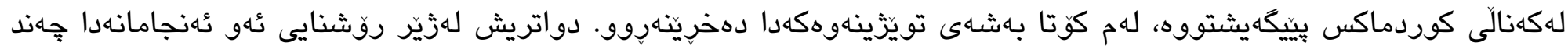

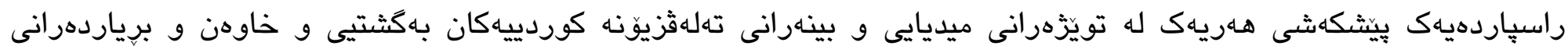

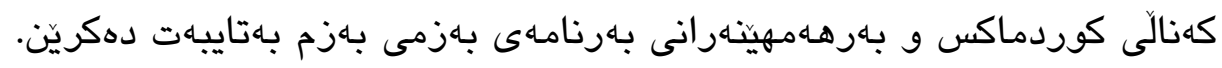

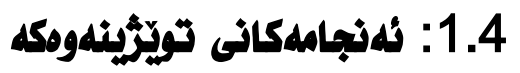

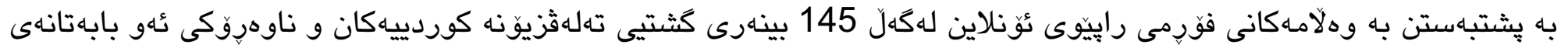

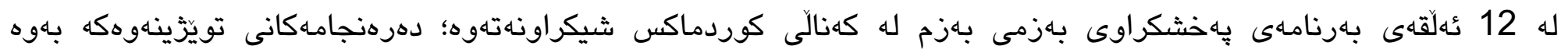

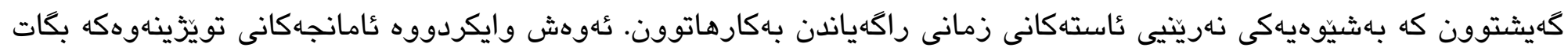

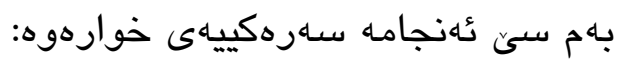


1. لهنيّو جوّرى ثاستهكانى زمانى راكهياندندا؛ هـاريهك له ئاستهكانى وشهاسازيى و رستهسازيى و واتاسازيى كاريكهرييهكى

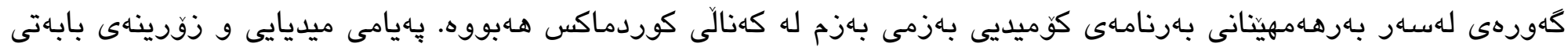

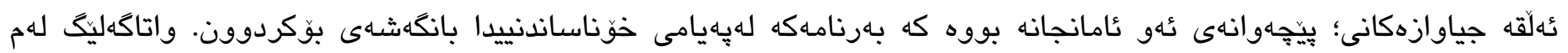

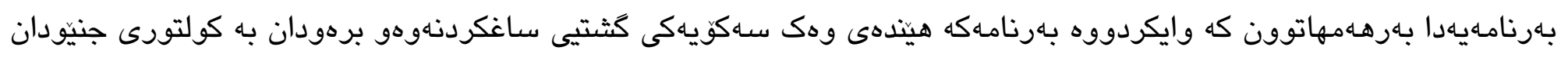

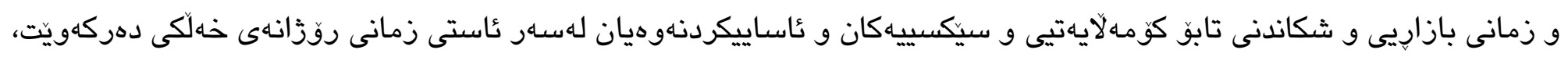

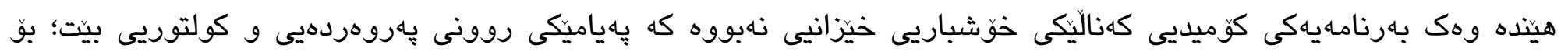

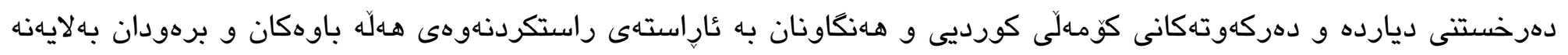

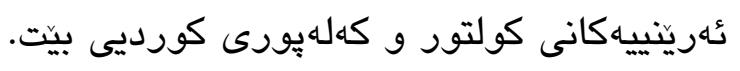

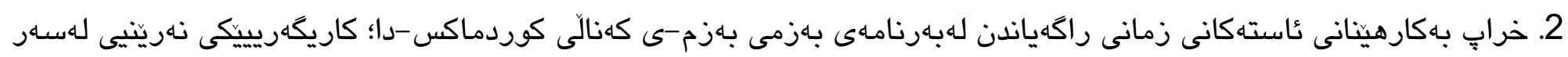

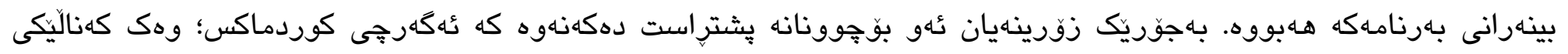

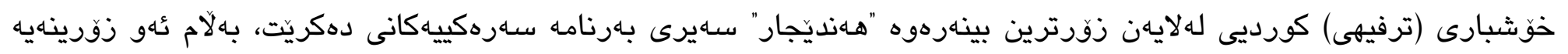

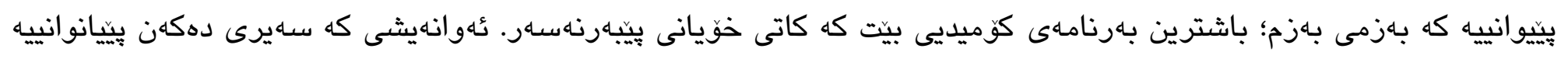

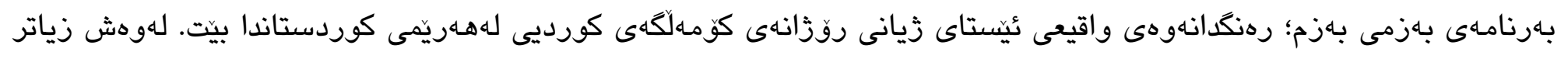

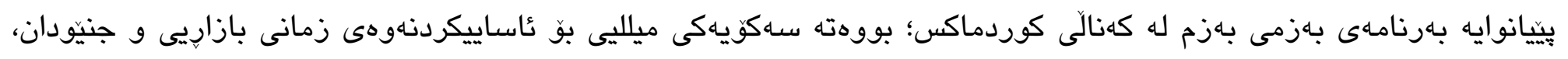

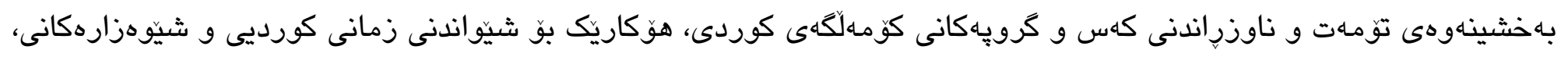

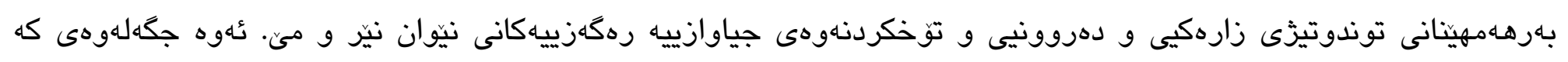

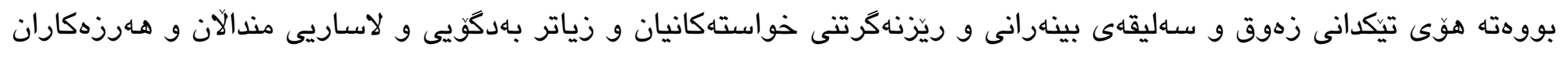

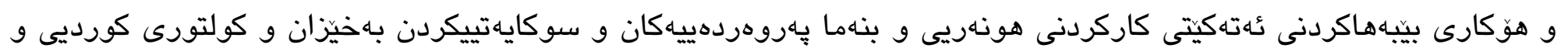
تايبهتمـاندييهكانى.

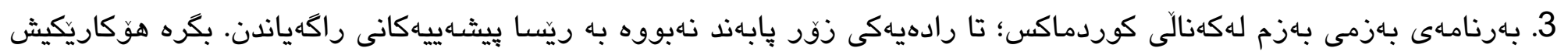

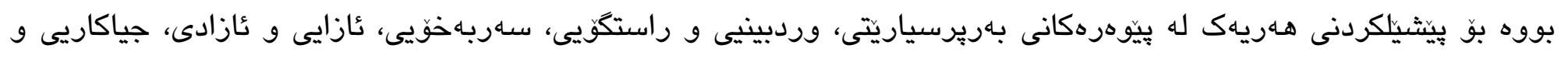

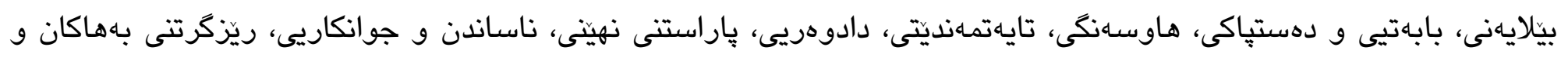

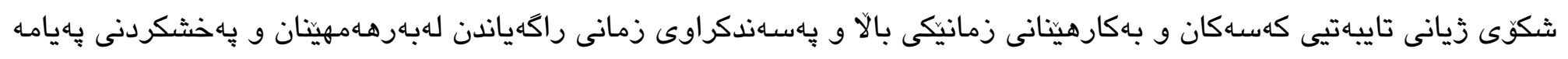
كوميدييهكانييدا.

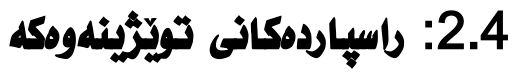

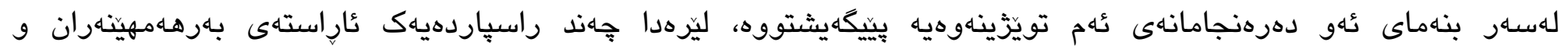

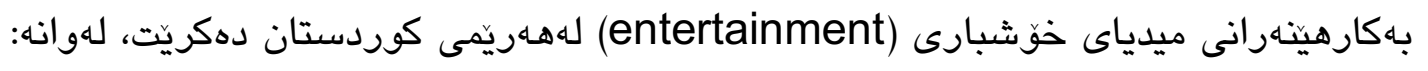

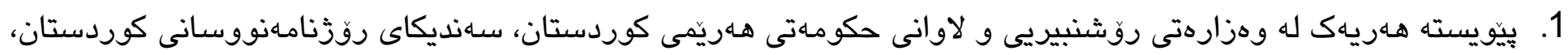

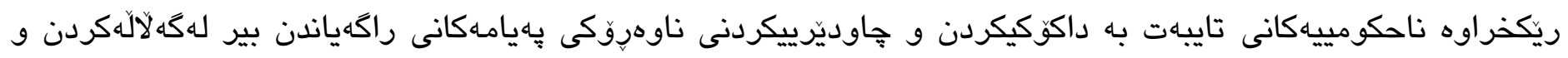

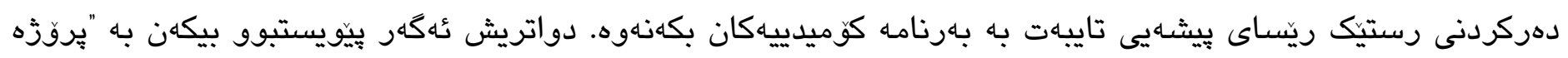




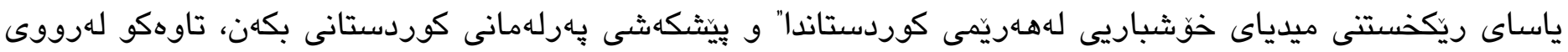

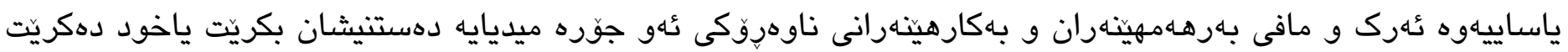

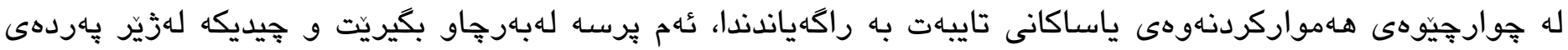

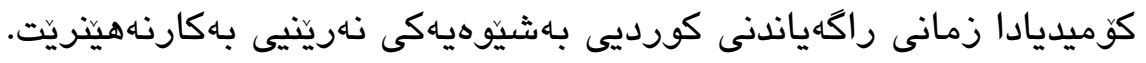

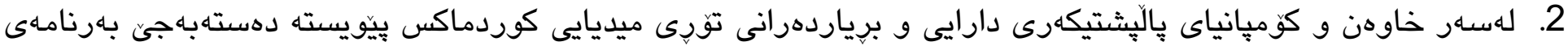

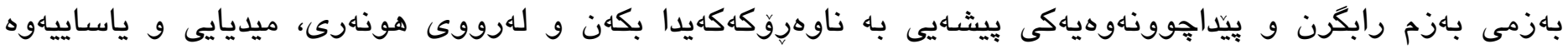

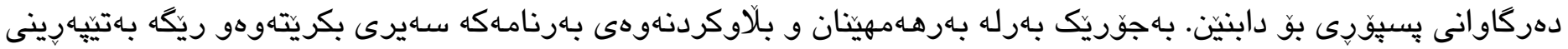

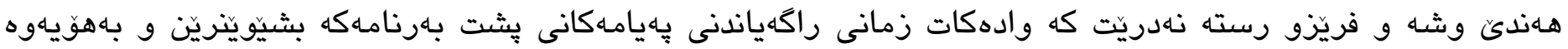

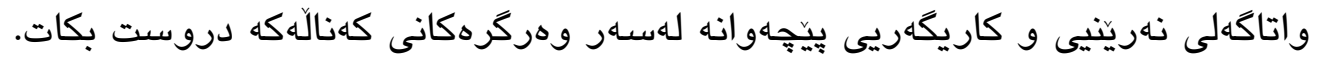

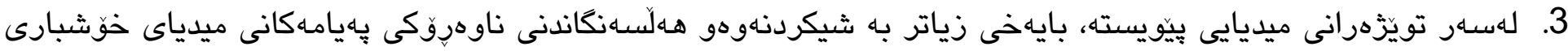

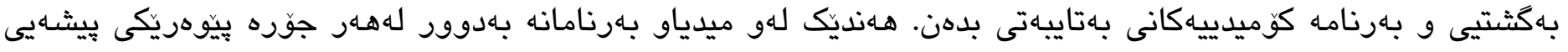

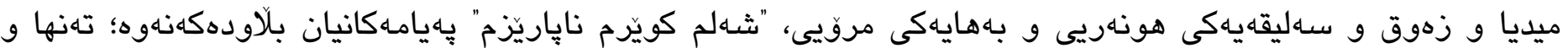

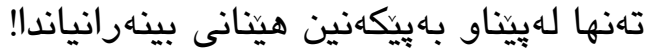




\title{
The Effects of Media Language Using of Comedian Program Audiences of Kurdish Televisions; BEZMÎ BEZM Program at KurdMax TV As A Case Study
}

\section{Shwan Adam Aivas}

Media Technical Department, Sulaimani Technical Institute, Sulaimani Polytechnic University, Sulaimani, Kurdistan Region, Iraq.

E-mail: shwan.adam@spu.edu.iq

\section{Mahabad Kamel Abdulla}

Kurdish Department, Sharazoor Education College, University of Halabja, Halabja, Kurdistan Region,Iraq.

E-mail: mahabad.abdullah@uoh.edu.iq

\begin{abstract}
:
This study is an attempt to evaluate the effects of media language misusing in comedian programs of Iraqi Kurdish televisions. To achieve this goal, the researchers have done an online survey with 145 TV viewers; as well as analyzing the thematic contents of 12 episodes of the BEZMÎ BEZM program on the KurdMax satellite channel.

Based on the research results; media language misusing in the BEZMÎ BEZM program has negative effects on viewers of this program, despite the fact that the majority of opinions agreed on the definition of this satellite as a Kurdish entertainment channel and the rates of views of its main programs "Great". However, they also agreed that this program on the KurdMax satellite channel has become a popular platform for insults, exchange of accusations, and defamation of certain personalities and groups in society, and a reason for sabotaging the Kurdish language and its methods, producing linguistic and psychological violence and highlighting gender discrimination. In addition to sabotaging the public taste of viewers, lack of respect for their needs, delinquency of adolescents, reducing the value of artistic work etiquette and educational foundations, and underestimating the family and Kurdish culture and its peculiarities. As for the topics presented in this program, the main goal is to make viewers laugh only and to achieve this; they do not hesitate to spread market language and archaic and patriarchal cultures, encourage gender differences of men and women, social and sexual taboos, defame personalities, neglect health guidelines, and violate professional media ethics. All of the above; represents the main identity of the BEZMÎ BEZM program on the KurdMax satellite channel. As a final point, this research has recommended the relevant people and bodies to subordinate such programs in order to review its content based on legal and ethical media standards, laws, and rules of the Kurdish language, along with abiding professional art principles.
\end{abstract}

Key words: Language, Media Language, Comedian Program, Kurdish Televisions, Professional Media Ethics and Bezmi Bezm Program. 


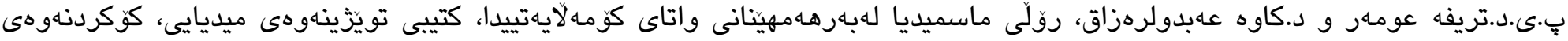

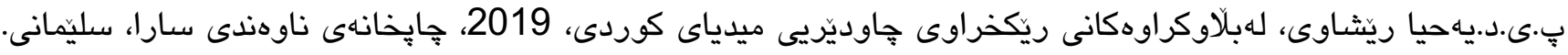

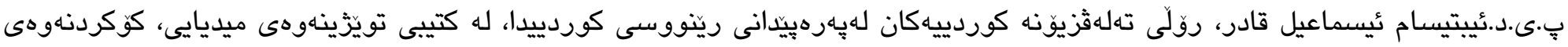

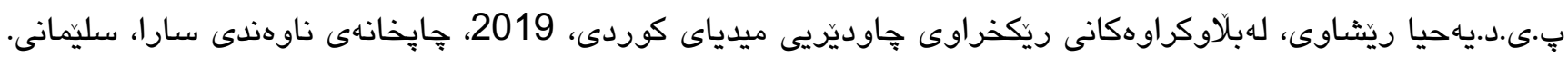

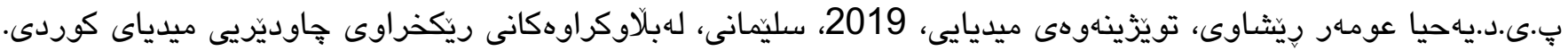

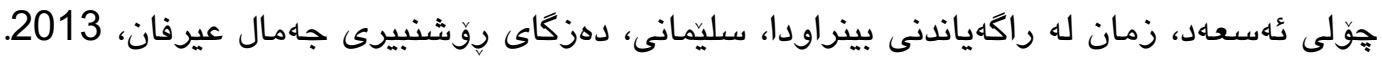

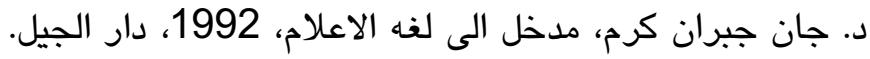

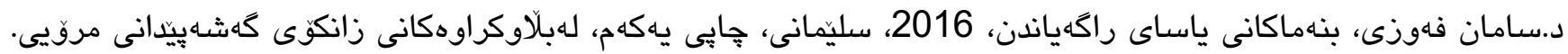

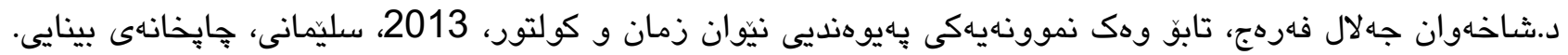

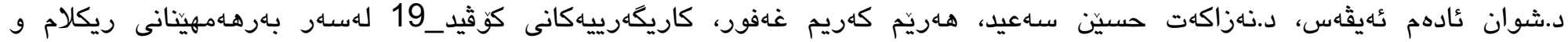
كهمكردنهوهى داهات؛ تهلهثزيونه كوردييهكان لهماوهى قهدهغهى هاتووجِّ له هـريّمى كوردستاندا، كؤثارى الدراسات السياسية والامنية، المجلد (الثالث) العدر (الخامس) حزيران 2020.

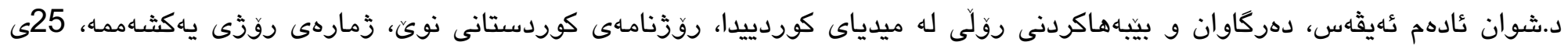
كابى 2020.

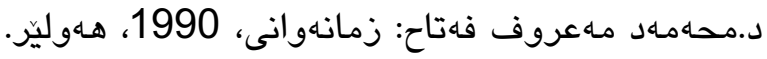

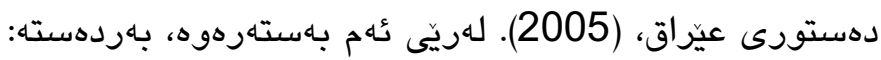
https://www.constituteproject.org/constitution/Iraq_2005.pdf?lang=ar

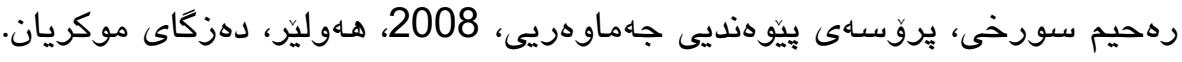

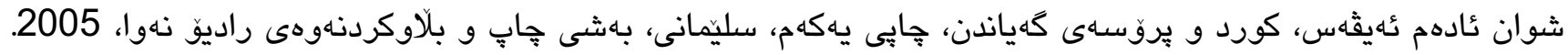

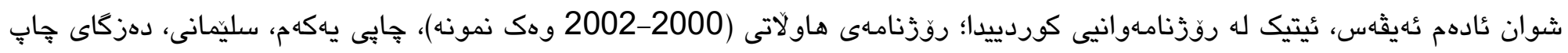

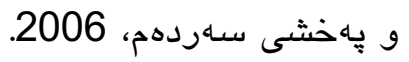

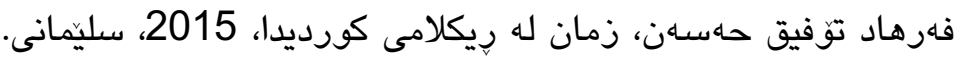

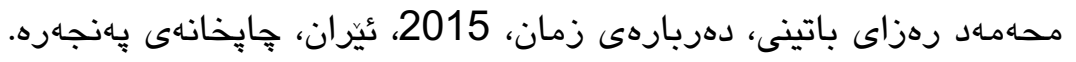

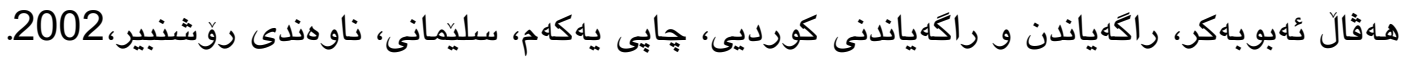

Aivas, Sh, A. (2017). Kurdish Journalism Cultures; Shifting Boundaries of Privacy Understandings amongst Professional Role Orientations of Journalists. (Doctoral dissertation, University of Nottingham Trent).

Henderson, J. (1993) Comic Hero versus Political Elite pp. 307-19 in Sommerstein, A.H.; S. Halliwell; J. Henderson; B. Zimmerman, eds. (1993). Tragedy, Comedy and the Polis. Bari: Levante Editori. 
Kuipers, G., 2006. Television and taste hierarchy: The case of Dutch television comedy. Media, Culture \& Society, 28(3), pp.359-378.

Syan, K. A. Q. (2017). Media in an emergent democracy: the development of online journalism in the Kurdistan region of Iraq (Doctoral dissertation, University of Bradford).

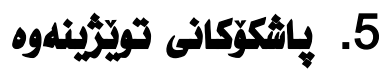

\begin{tabular}{|c|c|c|c|c|}
\hline \multicolumn{5}{|c|}{ 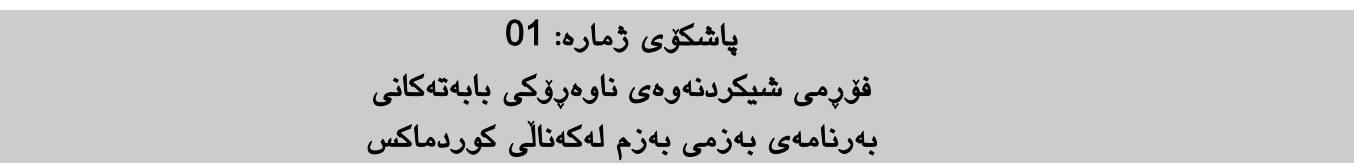 } \\
\hline بهستهرى بهرنامه & 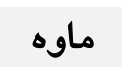 & ئهلَهى & ميزّوو & زنجيره \\
\hline $\begin{array}{l}\frac{\text { https://www.youtube.com/ }}{\text { watch?v=ES7M- }} \\
\text { RnZogk\&feature=youtu.be }\end{array}$ & 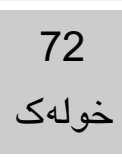 & 15 & 25 تهموزى 2020 & .01 \\
\hline$\frac{\text { https://youtu.be/jP6VAUD }}{\underline{\text { UfME }}}$ & 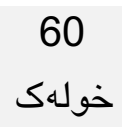 & 11 & 27 27ى حوزيرانى 2020 & .02 \\
\hline$\frac{\text { https://youtu.be/- }}{\text { e5i8oZd3lg }}$ & خولك & رهايبهت به رهنى & 25 ئايارى 2020 & .03 \\
\hline$\frac{\text { https://youtu.be/SfxwVxrf }}{\underline{\text { SyU }}}$ & 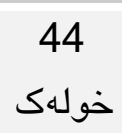 & 08 & 28ى نيسانى 2020 & .04 \\
\hline$\frac{\underline{\text { https://youtu.be/9I8IIQ4M }}}{\frac{\text { N3A?list=RDLK- }}{1 \mathrm{JFV89Jg}}}$ & 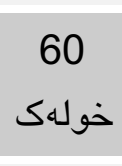 & 07 & 24ى ئادارى 2020 & .05 \\
\hline$\frac{\underline{\text { https://youtu.be/HerU6Ng }}}{\underline{\text { Qr2A }}}$ & 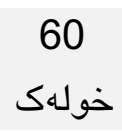 & 01 & 08 شى شوباتى 2020 & .06 \\
\hline$\frac{\text { https://youtu.be/5MdSfrm }}{\underline{\text { N4-s }}}$ & 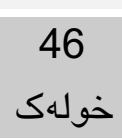 & 27 & 02 - مى تشرينى دووهمى 2019 & .07 \\
\hline$\frac{\text { https://youtu.be/bU0fTzBq }}{\underline{3 \mathrm{D} 0}}$ & خوله & 74 & 02 ئ ئهلولى 2019 & .08 \\
\hline$\frac{\text { https://youtu.be/wUV_aSo }}{\underline{\text { LOcs }}}$ & 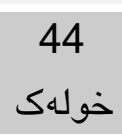 & 59 & 15ى حوزهيرانى 2019 & .09 \\
\hline$\frac{\text { https://youtu.be/o7XanKF }}{\underline{\text { GkMM }}}$ & 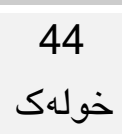 & 56 & 25ى ئايارى 2019 & .10 \\
\hline$\frac{\text { https://youtu.be/k1Cgu- }}{\underline{\text { J4Axc }}}$ & 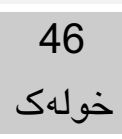 & 29 & 17 - اى تشرينى دوودمى 2018 & .11 \\
\hline$\frac{\text { https://youtu.be/YTQBHQ }}{\text { pefD8 }}$ & 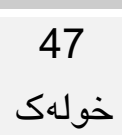 & 16 & 23ى حوزهيرانى 2018 & .12 \\
\hline
\end{tabular}




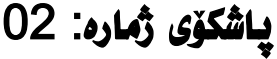

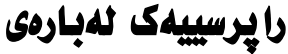

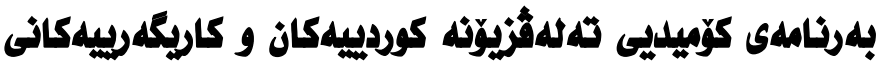

\section{بلهذاربووى بهريزّ:}

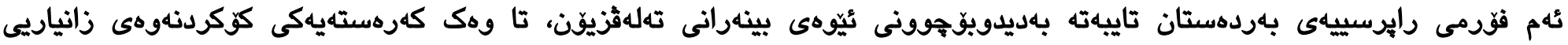

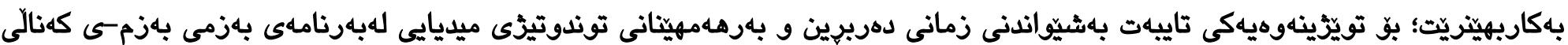

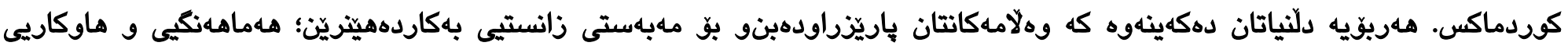

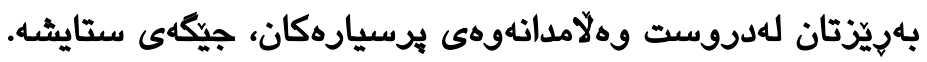

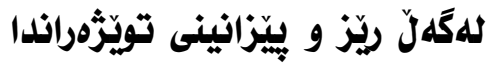

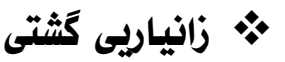

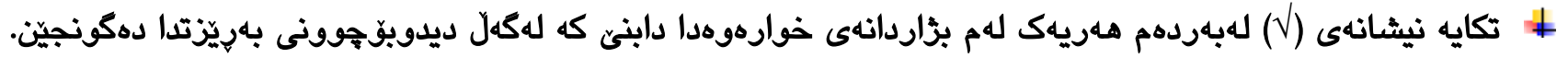

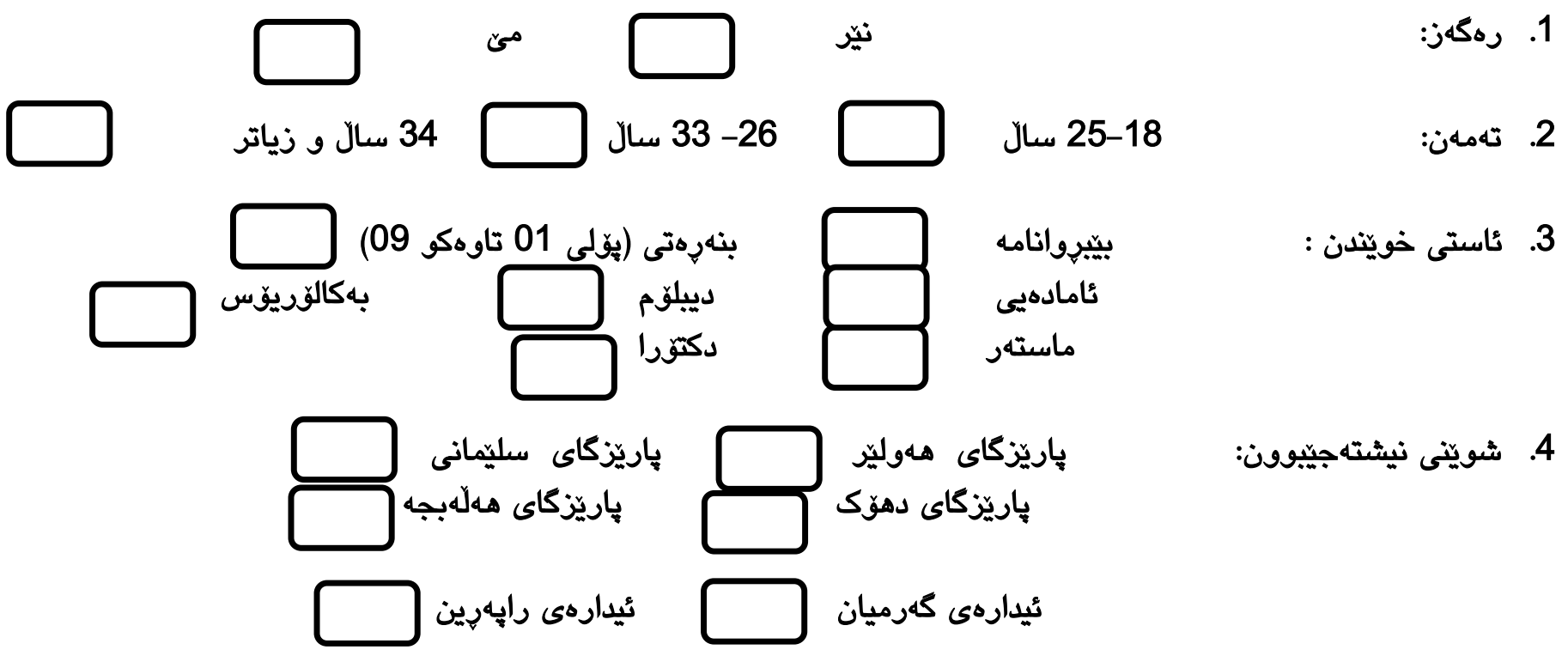


5. كوردماكس؛ وهك كهناليكى خوّشبارى (ترفيهى) كورديع سهيرى بهرنامه سهرهكييه كانى دهكه.

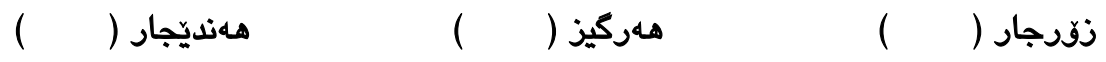

6 6. بهزمى بهزم لهكنالى كوردماكس؛ باشترين بهرنامهى كوميدييه كه كاتى خومى بييبهرمهسهر.

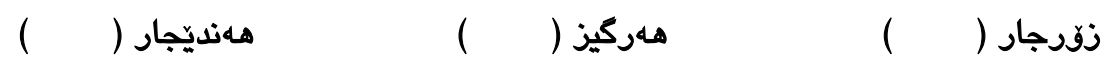

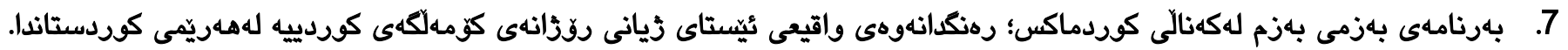

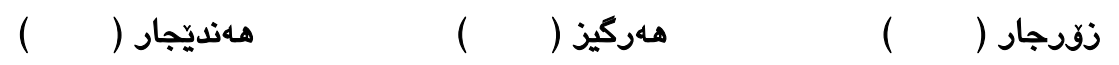

8. بهرنامهى بهزمى بهزم لهكهنالى كوردماكس؛ بووهته سهكويهكى ميليى بو ثاساييكردنهوهى زمانى بازائيى جنيودان و بهخشينهوهى تومهات و

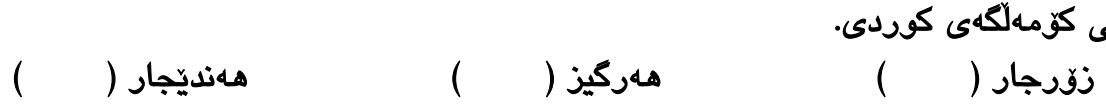

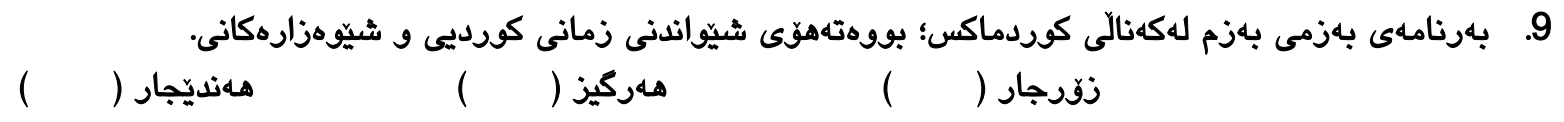
10. بهرنامهى بهزمى بهزم لهكهنالى كوردماكس؛ بووهتهوَى بهرهـمهينانى توندوتيزى زارهكيى و دهروونى.

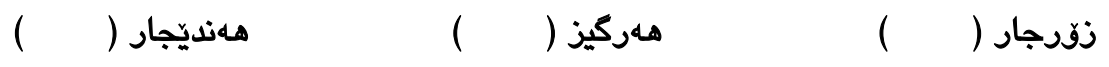
11. بهرنامهى بهزمى بهزم لككنالى كوردماكس؛ بووهتهوّى توخكردنهوهى جياوازييه رهكهزييهكانى نيوان نيّر و مئ.

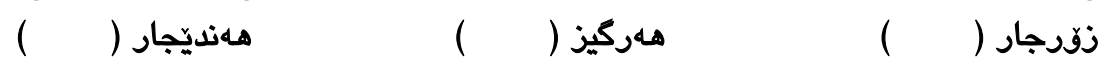

12. بهرنامهى بهزمى بهزم لكهنالى كوردماكس؛ بووهتهوَى تيكدانى زهوق و سهليقهى بينهرانى و ريزّنهرتنى خواستهانيان.

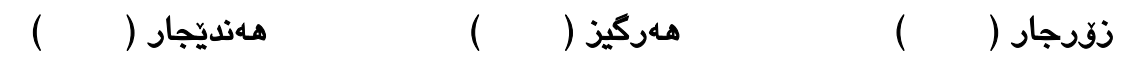
13. بهرنامهى بهزمى بهزم لككنالى كوردماكس؛ بووهتهوَى زياتر بهدكويى و لاساريى مندالان و هـرزهكاران.

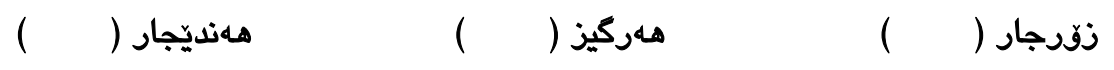

14. بهرنامهى بهزمى بهزم لهكهنالى كوردماكس؛ بووهتهوزى بييههاكردنى ئهتكيتى كاركردنى هونهريى و ييّيطيكردنى ييوهرهكانى ريّا بيشهييهكانى راكهياندن.

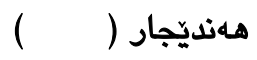

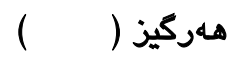
زورجار ( ) ( )

15. بهرنامهى بهزمى بهزم لهكهنالى كوردماكس؛ بووهتهؤى بييهماكردنى بنهما بهروهردهييهكان و سوكايهتييكردن بهخيزانى كورديى و تايبهتمهندييهكانى.

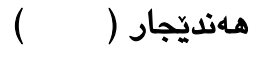

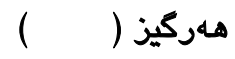
زورجار ( ( ) 